Illinois State University

ISU ReD: Research and eData

Theses and Dissertations

2-20-2014

\title{
No Blood in the Water: The Legal and Gender Conspiracies Against Countess Elizabeth Bathory in Historical Context
}

Rachael Leigh Bledsaw

Illinois State University, rlbledsaw@gmail.com

Follow this and additional works at: https://ir.library.illinoisstate.edu/etd

Part of the Eastern European Studies Commons, European History Commons, European Languages and Societies Commons, and the Women's Studies Commons

\section{Recommended Citation}

Bledsaw, Rachael Leigh, "No Blood in the Water: The Legal and Gender Conspiracies Against Countess Elizabeth Bathory in Historical Context" (2014). Theses and Dissertations. 135.

https://ir.library.illinoisstate.edu/etd/135

This Thesis is brought to you for free and open access by ISU ReD: Research and eData. It has been accepted for inclusion in Theses and Dissertations by an authorized administrator of ISU ReD: Research and eData. For more information, please contact ISUReD@ilstu.edu. 


\title{
NO BLOOD IN THE WATER: THE LEGAL AND GENDER CONSPIRACIES AGAINST COUNTESS ELIZABETH BATHORY IN HISTORICAL CONTEXT
}

\author{
Rachael L. Bledsaw
}

182 Pages

May 2014

This thesis explains and discusses the conspiracies reported against the Hungarian noblewoman, Countess Elizabeth Bathory, regarding her confinement and the arrest of her accomplices in December 1610. The conspiracies state that the Countess was unjustly targeted and charged not because she was guilty of the deaths of several dozen girls from torture, but because she represented a threat to the Hapsburg Empire due to her wealth, her political influence, and her widowhood. This thesis explores the rationality of these two conspiracies using historical context regarding the position of noblewomen in Central and Eastern Europe and the function and use of the Early Modern judicial system. It concludes that that there was no gender based conspiracy against the Countess because Early Modern Hungary did not see wealthy widows as a threat. Bathory did not seriously violate her expected roles and duties while a wife, widow, or a mother, and at her arrest had only a fraction of the power and wealth she held previously. Additionally the trial against her accomplices was conducted under standard Early Modern judicial procedures, including the use of torture to obtain a confession. 

NO BLOOD IN THE WATER: THE LEGAL AND GENDER

CONSPIRACIES AGAINST COUNTESS ELIZABETH

BATHORY IN HISTORICAL CONTEXT

RACHAEL L. BLEDSAW

A Thesis Submitted in Partial Fulfillment of the Requirements for the Degree of

MASTER OF SCIENCE

Department of History

ILLINOIS STATE UNIVERSITY

2014 
All rights reserved

INFORMATION TO ALL USERS

The quality of this reproduction is dependent upon the quality of the copy submitted.

In the unlikely event that the author did not send a complete manuscript and there are missing pages, these will be noted. Also, if material had to be removed, a note will indicate the deletion.

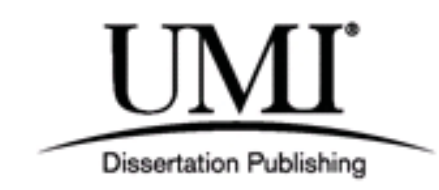

UMI 1562542

Published by ProQuest LLC (2014). Copyright in the Dissertation held by the Author.

Microform Edition () ProQuest LLC.

All rights reserved. This work is protected against unauthorized copying under Title 17, United States Code

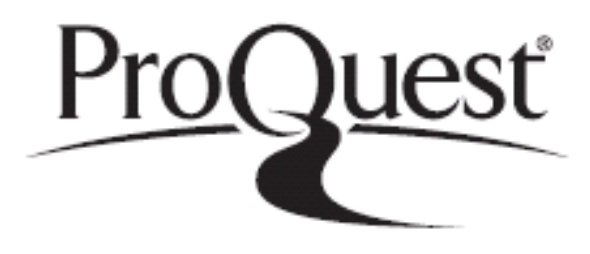

ProQuest LLC.

789 East Eisenhower Parkway

P.O. Box 1346

Ann Arbor, MI 48106 - 1346 
Copyright 2014 Rachael L. Bledsaw 
NO BLOOD IN THE WATER: THE LEGAL AND GENDER

CONSPIRACIES AGAINST COUNTESS ELIZABETH

BATHORY IN HISTORICAL CONTEXT

RACHAEL L. BLEDSAW

COMMITTEE MEMBERS:

William Reger, Chair

Christine Varga-Harris

Katrin Paehler 


\section{ACKNOWLEDGEMENTS}

This thesis is dedicated to Daniel Bledsaw, my amazing and wonderful husband. Without his constant support and encouragement, I would never have finished this thesis. I could not ask for a more understanding, compassionate, and brilliant partner. Additional thanks go out to my family and friends for their interest in the progress and information in this thesis - even if they did not always understand it. Finally thanks go to my committee members for agreeing to help with this thesis. My thanks and gratitude goes out to all of you.

R.L.B. 


\section{CONTENTS}

ACKNOWLEDGMENTS $\quad$ i

CONTENTS

TIMELINE

MAP

INTRODUCTION 1

CHAPTER

I. THE INFAMOUS BLOODY COUNTESS DRACULA: BIOGRAPHY OF COUNTESS ELIZABETH BATHORY 28

II. BELOVED LITTLE MONSTERS? RAISING A NOBLE CHILD IN EARLY MODERN EUROPE

III. LADY AND MISTRESS OF ALL SHE SURVEYS: WOMANHOOD AND NOBILITY IN EARLY MODERN HUNGARY 67

IV. VICTIMS AND PERPETRATORS: WOMEN AND VIOLENCE IN EARLY MODERN EUROPE AND HUNGARY

V. SPONTANEOUS TRUTHS AND THE POWER CENTER: JUSTICE IN EARLY MODERN EUROPE

VI. AWKWARD BEDFELLOWS: THE COUNTESS AND EARLY MODERN HUNGARIAN JUSTICE 


\section{TIMELINE}

1514

An anti-feudalist revolt is put down in Hungary

1517

The Tripartitum becomes the law of the land, enforcing further restrictions on serfs and detailing the rights of nobles

The Battle of Mohacs and the death of King Louis II

King John I and King Ferdinand I are both elected as King of Hungary by the Diet Civil War

John and Ferdinand sign a treaty that names Ferdinand John's heir

John I dies, his son, John II named King

Hungary is divided into three parts: Royal Hungary, Ottoman Hungary, Principality of Transylvania

Elizabeth Bathory is born

1571

Francis Nadasdy is given first choice of Elizabeth as wife

Elizabeth Bathory and Francis Nadasdy are engaged

Elizabeth Bathory and Francis Nadasdy are married

Elizabeth is given Castle Cjesthe as a dower

Francis Nadasdy leaves on his first campaign against the Ottomans

Elizabeth Bathory gives birth to Anna Nadasdy

Two more daughters follow, exact year unknown

Fifteen Years War begins

Secret burials led by Elizabeth begin

1596

Andrew Nadasdy was born (died in infancy)

1598

Paul Nadasdy was born 
Anna Durvulia becomes friend and companion to Elizabeth

Francis returns home from war gravely ill

1602

Rumors begin to circulate about murders of servant girls serving Elizabeth

1604

Francis dies of unknown disease

1605

Elizabeth's brother dies

Elizabeth retires to Castle Cjesthe

Bocskai Rebellion against the Hapsburgs begins

1606

Bocskai Rebellion ends

Fifteen Years War ends

1608

Matthias II coroneted King of Hungary and Holy Roman Emperor

1609

Anna Durvulia dies of a stroke

Elizabeth opens a gynaeceum

George Thurzo is elected Palatine

Matthias II orders Thurzo to investigate Elizabeth for murder

1610

Investigation of Elizabeth goes from March-July

Thurzo makes a deal with Paul Nadasdy, Imre Megyeri, and sons-in-law to arrest Elizabeth, but keep her from going to trial

Thurzo confronts Elizabeth with the evidence against her on Christmas Eve, Elizabeth claims innocence

Thurzo leads a raid on Castle Cjesthe on New Year's Eve, places Elizabeth under house arrest, arrests her accomplices

1611

Ilona Jo, Janos Fiziko, and Dorottya Szentes are executed

Katalin Beneczky is imprisoned for life, later released

Matthias II demands Elizabeth is brought to trial until 1613

1614

Elizabeth Bathory dies at the age of 55 


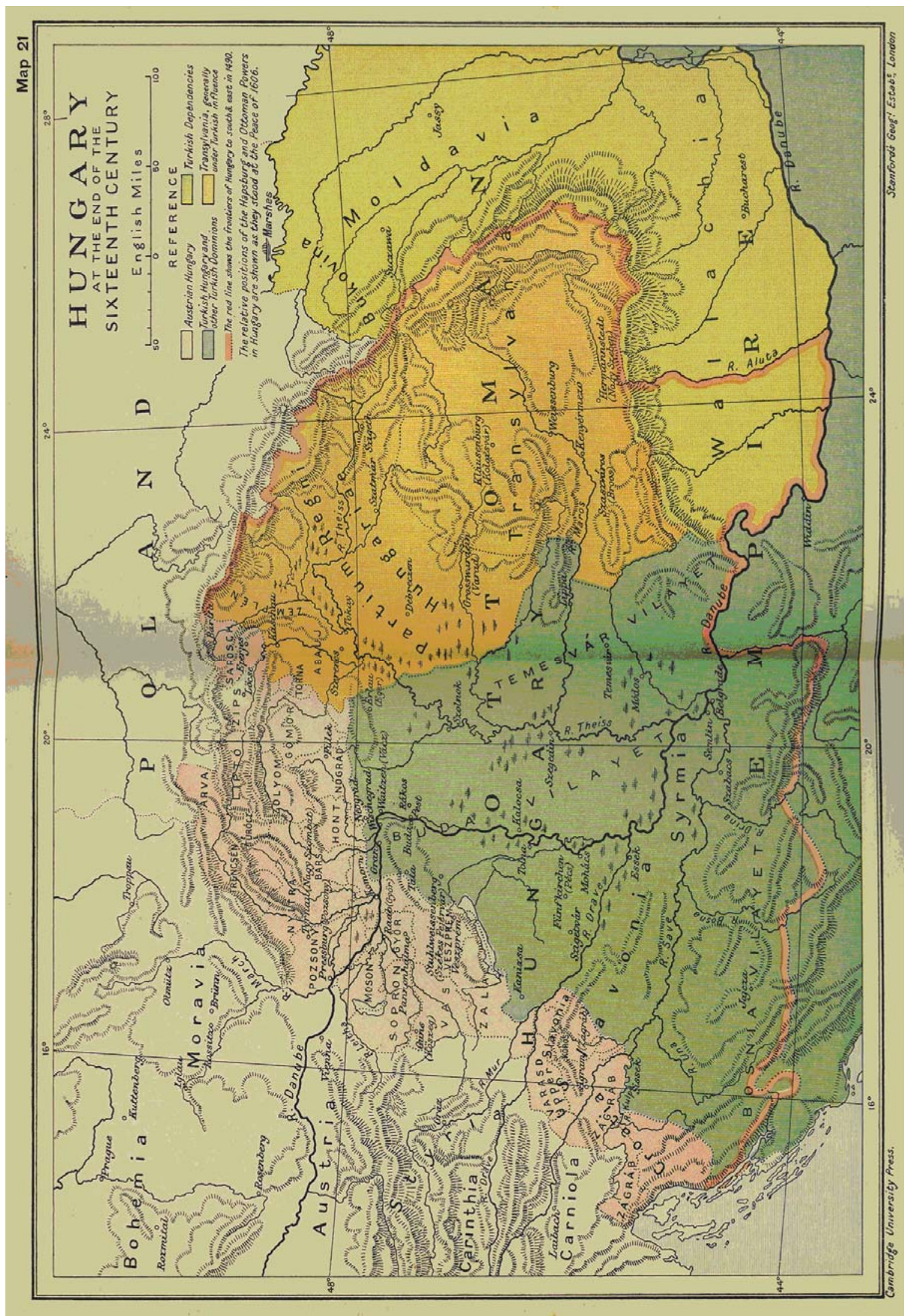




\section{INTRODUCTION}

\section{THE LADY ONLY WORE CRIMSON:}

\section{ELIZABETH BATHORY}

\section{AND HER LEGEND}

Serial killer. Sadist. Mad woman. Vampire. Werewolf. Countess Elizabeth Bathory has been called all of these names and more over the course of history for her crimes involving the brutal torture and murder of an unknown number of young women and girls. After a raid of her castle, Cjesthe, on December 29, 1610, by Palatine George Thurzo, the Countess' sons-in-law, and her son's legal guardian and tutor, she was confined to her rooms while the four servants who had assisted her were tried and executed for their part in the murders. Officially Countess Bathory was charged with the deaths of eighty girls, but the total number of victims will never be conclusively known. It could range between fifty, the highest number recalled by her oldest accomplice, Ilona Jo, to six hundred and fifty, a number claimed by Suzannah, a peasant witness during preparation for a trial that never happened. ${ }^{1}$ Still proclaiming her innocence while under effective house arrest, the Countess died at the approximate age of fifty-four in mid to late August 1614. After her death the story of her murders was locked away and lost for

\footnotetext{
${ }^{1}$ Kimberly Craft, Infamous Lady: The True Story of Countess Erzsebet Bathory (Lexington:Kimberly Craft, 2009), 140, 161; Tony Thorne, Countess Dracula: The Life and Times of Elisabeth Bathory (London: Bloomberg Press, 1997), 52; Raymond T. McNally, Dracula was a Woman: In Search of the Bloody Countess of Transylvania (New York: McGraw Hill, 1983), 79; Valentine Penrose, The Bloody Countess, trans. Alexander Trocchi (London: Colder and Boyors, 1970), 168.
} 
nearly a century, though it continued to exist in the stories and legends of the common people around Cjesthe.

Because she existed mostly in folklore for over a century, very little scholarly attention was paid to the Countess. She was relegated to the netherworld of true crime writers and the hyperactive imaginations of gothic novelists. Depending on the location, the Countess was either a celebrity for her infamy or for her victimhood. In the last two decades of the twentieth century, she became a particularly popular figure for the evils of foreign oppression and gender based conspiracy in Hungary. Blogs of fans fixated on early 1980s research comparing what happened to her and her accomplices to the show trials of the Communist era. ${ }^{2}$ The interpretation was exaggerated to make her the personification of Hungarian suffering under Communism, and therefore particularly attractive to Hungarian national pride and scholarship. This reinterpretation of the Countess is popular in Eastern Europe, but less so elsewhere.

In the West, Bathory found her way into popular, or at least non-academic, biographies, true crime stories and novels, but she was little more than a gruesome anecdote in academia. This has been not only unfortunate, but a missed opportunity to analyze a case study of power, womanhood, and justice in Early Modern Hungary. Although gaps exist in the case, the questioning of the witnesses -- over three hundred of them -- were documented, as were Palatine Thurzo's legal deviations. Rather than ignoring the case because it was so eagerly adopted by folklore, the case of Countess

\footnotetext{
2 This list of blogs is by no means final or complete, but intended to give the reader a starting place. Szegard Bori, http://www.jovonk.info/2012/02/13/bathory-erzsebet-tragikus-sorsa-2; Susan Nernath Vanyi, http://hetek.hu/hatter/201002/bathory_veres_legendaja; http://www.nagybanya.ro/reszletes-cikkid1538.htm; http://hirek.oldal.info/hír/_2010/02/11/3322616/Báthory véres legendája/y2010/m02/d11; http://anapologiaforcountesserzebetbathory.blogspot.com/2012_05_01_archive.html. 
Bathory should illustrate how Early Modern justice conventionally functioned in Eastern

Europe outside the parameters of witch hunts (which were a gross abuse of legal and social authority regardless of location.) It also provides insight into an aristocrat's place in Eastern and Central Europe, particularly in the legal system, marriage, widowhood, and medicine. ${ }^{3}$ Women and femininity were by no means considered equal to men and masculinity in Eastern Europe, but there was more appreciation for stronger, assertive, women considered oddities in the west. But first, Bathory's case has to be put into social and historical context.

The main purpose of this thesis will be to discuss Countess Elizabeth Bathory within a historical and cultural framework rather than the sensationalist, true crime, and occult lenses through which she was viewed in previous works. Specifically it will reject arguments that Bathory was targeted for persecution because she was a wealthy and powerful widow. Contemporary and modern works on the construction of womanhood in Eastern Europe counter this perception. ${ }^{4}$ The fear of powerful single women and widows was far more present in Western Europe than in the East. Widows were an accepted part

\footnotetext{
${ }^{3}$ Although Hungary is set solidly in Central Europe presently, I have chosen to refer to it as Eastern although such a designation smacks of Cold War mentality. I have chosen to do so because for much of the $16^{\text {th }}$ century, Hungary was Eastern Europe since Muscovy was largely agreed to be the limits of Europe. Additionally, the Holy Roman Empire controlled Central Europe and while Hungary was ruled by Hapsburgs, it was not part of the Holy Roman Empire.

${ }^{4}$ Sharon L. Jansen, The Monstrous Regiment of Women: Female Rulers in Early Modern Europe (New York: Palgrave Macmillian, 2002), 1-2; Teresa A. Meade, "Structures and Meanings in a Gendered Family History," in A Companion to Gender History ed. Teresa A. Meade and Merry E. Wiesner-Hanks (Molden: Blackwell Publishing, 2004), 65; Nancy Shields Kollman, "Self, Society, and Gender in Early Modern Europe" in Gender History, Meade and Wiesner-Hanks, 360-361; Cissie Fairchilds, Women in Early Modern Europe 1500-1700 (Harlow: Pearson Longman, 2007), 22-23; Sharon D. Michalove, "Equal Opportunity? The Education of Aristocratic Women, 1450-1540," in Women's Education in Early Modern Europe: A History 1500-1800, ed. Barbara J. Whitehead (New York: Garland Publishing Inc., 1999), 51; Maria Bogucka, Women in Early Modern Polish Society Against the European Background. (Burlington: Ashgate Publising Company, 2004), 178; Frances E. Dolen, "Gender and Sexuality in Early Modern England," in Gender, Power, and Privilege in Early Modern Europe, ed. Jessica Munns and Penny Richards (London: Pearson Education Limited, 2003), 8; Ian Madean, The Renaissance Notion of Women: A Study in the Fortunes of Scholasticism and Medical Science in European Intellectual Life (Cambridge: Cambridge University Press, 1980), 6.
} 
of life, indeed the best time of a woman's life -- particularly if they were wealthy and noble. Finally, it will also discredit the long held belief that the investigation of Bathory and the trial of her four accomplices was illegal or in anyway similar to the show trials of the Communist era. Letters between family members and Palatine Thurzo revealed a preceding agreement to avert a trial. This was to avoid actual sentencing, rather than a political conspiracy to deprive her of her noble rights. Thurzo gathered evidence according to the Early Modern Hungarian legal code, up to and including his use of torture to gain a confession. The modern understanding of torture within the Early Modern justice system was skewed by its excessive use during witch hunts and religious persecutions. The use of judicial torture was considered necessary and expected to ensure a proper trial under the inquisitional system.

Works on Bathory divide into three groups: the early works, the later works, and true crime. The early works focused on the sensationalism of her story. ${ }^{5}$ Specifically delighting in repeating and furthering rumors of the Countess bathing in blood to maintain her beauty, these focused more on the horrible nature of her crimes rather than on the woman herself. Many of these early works had various agendas, were part of travel logs, or were based entirely on the inflated stories of peasants and not any academic methodology.

\footnotetext{
${ }^{5}$ John Paget, Hungary and Transylvania; With Remarks on their Condition, Social, Political, and Economical (Philadelphia: Lea \& Blanchard, 1850), 49-51; Sabine Baring-Gould, The Book of Werewolves: Being an Account of a Terrible Superstition (New York: New York Causeway Books, 1973), 139-141; Penrose, Bloody Countess, 9.
} 
The first monograph on Bathory was written in 1760 by the Jesuit scholar Brother Laszlo, who discovered the transcripts for the accomplices' trial and summarized them. ${ }^{6}$ His manuscript was the first to include the bathing-in-blood-for-youth element which became the cornerstone of the Bathory mythology. The obvious question was why add this to his manuscript? Though largely up for speculation, Laszlo likely saw the chance to use Bathory to address issues during his lifetime regarding religion and fledgling ideas of nationalism. Bathory was a Protestant who held power before the Counter-Reformation had much of an impact in Hungary, while Laszlo was a Catholic writing for a Catholic monarchy, the Hapsburgs. By the time Laslzo wrote, many aristocratic families had converted back to Catholicism to gain favor within the Hapsburg court. Further demonizing any Protestant faith stymied any possible converts. Re-conversion was a strong possibility, since at the time he was writing, Hungary, Austria and other Eastern European countries were in the throws of both vampire paranoia and rebellions against the Hapsburg monarchy. Laszlo writing and publishing a manuscript which portrayed a Hungarian noble as a diabolical and overly cruel creature fed into already present vampire fears of the time as well as damaged the proto-nationalistic pride of Hungarians.

Over the course of the nineteenth century the Western world received more snippets of the legend of Countess Bathory from religious persons and from popular culture. Michael Wagner, a German scholar, wrote a brief entry on the Countess in his own travelogue which was quoted in its entirety by Reverend Sabine Baring-Gould in his 1865 book, The Book of Werewolves: Being an Account of a Terrible Superstition. The entry on Bathory was included as part of a discussion on how some people simply

\footnotetext{
${ }^{6}$ Penrose, Bloody Countess, 7-8; Thorne, Countess Dracula, 7; Craft, Infamous Lady, 189; McNally Dracula was a Woman, 11.
} 
enjoyed the suffering and pain of others. In no way were Wagner or Baring-Gould suggesting or insinuating that Bathory was a werewolf. The text, quoted in full below, repeated the myth of bathing in blood, but added that she was driven to do it to please her husband and for her own vanity. The total killed was brought up to six hundred and fifty from Brother Laszlo's six hundred, which he arrived at after totaling up the number that the witnesses claimed. ${ }^{7}$ Again, however, the focus was less on the Countess herself and more on the description of her crimes and the motivation for them.

Elizabeth --------- was wont to dress well in order to please her husband, and she spent half the day over her toilet. On one occasion, a lady's maid saw something wrong in her head-dress, and as a recompense for observing it, received such a severe box on the ears that the blood gushed from her nose, and spirited on to her mistress's face. When the blood drops were washed off her face, her skin appeared much more beautiful - whiter and more translucent on the spots where the blood had been.

Elizabeth formed the resolution to bathe her face and her body in human blood so has to enhance her beauty. Two old women and a certain Fitzko assisted her in her undertaking. This monster used to kill the luckless victims, and the old women caught the blood, in which Elizabeth was wont to bathe at the hour of four in the morning. After the bath she appeared more beautiful than before.

She continued this habit after the death of her husband (1604) in the hopes of gaining new suitors. The unhappy girls who were allured to the castle, under the plea that they were to be taken into service there, were locked up in a cellar. Here they were beaten till their bodies were swollen. Elizabeth not unfrequently tortured the victims herself; after she changed their clothes which dripped with blood, and then renewed her cruelties. The swollen bodies were then cut with razors.

Occasionally she had the girls burned, and then cut up, but the great majority were beaten to death. At last her cruelty became so great, that she would stick needles into those who sat with her in her carriage, especially if they were of her own sex. One of her servant girls she stripped naked, smeared her with honey, and so drove her out of the house. When she was ill, and could not indulge her cruelty, she bit a person who came near her sick bed as though she were a wild beast. She caused, in all the death of 650 girls, some in Tscheitia, on the neutral ground, where she had a cellar constructed for this purpose; others in different localities; for murder

\footnotetext{
${ }^{7}$ McNally, Dracula was a Woman, 13.
} 
and bloodshed became with her a necessity. When at last the parents of lost children could no longer be cajoled, the castle was seized, and the traces of the murders were discovered. Her accomplices were executed, and she was imprisoned for life. ${ }^{8}$

Although Baring-Gould intended not to do anything more than introduce the existence of sadists, Wagner's short piece cleanly laid out the main points of the Bathory myth; vanity, cruelty, and noble power abuse. Additionally, Wagner outlined the basic tortures used against the girls. All of these elements appear in other biographical works on Bathory with increasing detail and research.

Around the same time, John Paget's two part travelogue on Hungary and Transylvania was published. In it, he described his trip to visit the Castle Cjesthe and recounted in simple terms the story his guide told him. His guide's story was similar to Wagner's account, though it did not to go into detail about the methods of killing. Paget claimed they were too horrible to recount to the refined Western audience for whom he wrote. He also lowered the body count to three hundred. ${ }^{9}$

Up until this point, very little of the Countess' personality or personal habits, aside from sadistic ones, had been written about. In 1904 R. A. von Elsburg's work changed that. Considered by McNally to be the best biography on Bathory, it was based entirely on the stories of peasants and folklore of the area. ${ }^{10}$ It was in von Elsburg's text that accusations of adultery, lesbianism, and illegitimate children were first brought into the fold of the story of Bathory. ${ }^{11}$ It remains unclear why von Elsburg included these pieces in his work, but most likely over the three hundred years since the Countess' death

\footnotetext{
${ }^{8}$ Baring-Gould, Book of Werewolves, 139-141.

${ }^{9}$ Paget, Hungary, 50.

${ }^{10}$ McNally, Dracula Was a Woman, x; Craft, Infamous Lady, 30-31.

${ }^{11}$ Craft, Infamous Lady, 31.
} 
her story was engorged with the occult, mysticism that was the fin-de-siècle, and anything else that would have made her the ideal villain. Since his source was only folktales, the accuracy is questionable, but many of his assertions remain part of the legend. For decades the West saw Bathory only through plays, stories, and operas. The result was a skewed view of not only Bathory, but the old Eastern European ways in general.

Half a century after von Elsburg, the Western world finally had an academic resource on the Countess presented to them in French and English, though the English translation would not appear until the early 1970s. Valentine Penrose, like the other early works, accepted the Countess' guilt wholesale and without question in her book, The Bloody Countess. She also accepted that Bathory was either a lesbian or a bisexual who had an incestuous relationship with her Aunt Klara (who herself was supposedly a murderess and sexually insatiable), and that she spent much of the time her husband was away fighting the Turks having the sort of parties that Roman emperors dreamed of. ${ }^{12}$ Penrose was not a historian, but rather a poet and writer. While this made some of her conclusions questionable and her prose a flowery chore to get through, Penrose was the first Western writer to use the primary source material for her book. She supported and expanded on many unconfirmed details of the Countess, but she refuted the myth of bathing in blood. ${ }^{13}$ She focused more on the crimes and spent much of her work highlighting the sexual and mystical parts of the legend. Therefore, although Penrose did use primary source material to debunk stories of vampirism and blood bathing, she exacerbated the rumors of sexual infidelity and perversion.

\footnotetext{
${ }^{12}$ Penrose, Bloody Countess, 26, 31.

${ }^{13}$ Penrose, Bloody Countess, 67, 117.
} 
Penrose also provided a pseudo-psychological reason for why Bathory would lash out at young, pretty, women. Rather than doing so to gather and bathe in their blood, she did so because she was driven astrologically. Penrose argued that the time of her birth placed her under a masculine sign, which excited her lesbian tendencies and caused her to lash out against small, weak, things. ${ }^{14}$ Although largely insupportable because of its basis in astrology, Penrose's explanation for Bathory's actions must be given credit for taking the focus off lycanthropy or vampirism. Her return to Brother Laszlo's monograph and the transcript of the trial as sources set her apart from the other early works in regards to methodology and certainly inspired later biographers; however, her focus on the sensational elements and her astrology based explanation for the crimes prevented her from fully separating her work from the earlier ones.

Beginning with Brother Laszlo and ending with Penrose, the early works all share specific traits and arguments regarding the Bathory myth. First, all of them accept her guilt without question and without a need (or maybe desire) to place her actions within historical context. Secondly, their construction of the Countess was simple: she was cruel and evil, a personification of all that was wrong with nobility. There was no discussion of conspiracy or show trials, and there was no attempt to make her into a victim or a much maligned national hero. The early works focused solely on her crimes and her torture methods.

The main distinction between early works on Bathory and later ones was that later works brought some social context into her story; they began to focus more on Bathory's

\footnotetext{
${ }^{14}$ Penrose, Bloody Countess, 26. For those who do know astrology and horoscopes, Bathory's birthday on August 7, 1560 would make her a Leo, which is indeed a masculine fire sign. Of course this would also have to mean that horoscope signs have any kind of real bearing on the actions of people, which has not been proven.
} 
position as a wife and mother rather than her well established crimes. It would be the later works which truly introduced accusations of conspiracy regarding her case. Later works employed a stronger academic methodology by repeatedly returning to the trial documents and working to uncover lost letters to or from Bathory from the archives of the Nadasdy, the Batthyany, and the Thurzo families. With these new letters and documents, later authors were able to create a wider picture of the Countess's world and how she may have lived -- though some with more success than others. Many of these works relied on untranslated research material by Hungarian and other Eastern European scholars as secondary source material. Through these later works, English readers were given insight into her cultural and position in Hungary.

The first of these later works, Dracula was a Woman: In Search of the Blood Countess of Transylvania, written by the historian Raymond T. McNally, appeared in 1983. McNally's involvement in the story of Countess Bathory was actually a step back from rescuing her from the world of vampires and werewolves. McNally was at the time the eminent scholar for all things Dracula, from Vlad to Abraham Stoker himself. ${ }^{15}$ His previous four books all dealt with the subject of vampires in Eastern Europe, or sought to correlate the inspiration of the literary blood-sucking count with the Wallachian war lord, Vlad the Impaler. Attaching his name to the Bathory case, therefore, created the impression that there was truth to the stories of vampirism. This was not helped when

\footnotetext{
${ }^{15}$ Dr. Raymond T. McNally had published four books on Dracula and Bram Stoker before his book on Bathory. A professor in Russian and Eastern Studies, McNally taught at Boston College for several decades.
} 
McNally misunderstood Baring-Gould's inclusion of her in his book and reported that she was considered a werewolf. ${ }^{16}$

Like Penrose, MacNally rejected the legend of her bathing in blood, but supported the stories of sexual sadism, affairs, lesbianism, and an illegitimate child. His sources for all of these stories were questionable. He presented folklore as scholarly evidence, while failing to do so in a way that future researchers could replicate. He claimed that the story of Bathory's illegitimate child was recorded in detail in Ursula Nadasdy's letters, but no such evidence was found - or even mentioned - by any other authors. ${ }^{17}$ He argued that she was driven to perform the cruel and shocking murders because of revenge against her overbearing mother-in-law, ${ }^{18}$ which was rejected by later authors largely on the basis that not only were Bathory's own parents dead before she was married, but so were her inlaws. ${ }^{19}$ In short, McNally wrote a book on a topic he knew very little about, and presented his own opinion as supporting evidence.

McNally's main contribution, however, was his introduction of the idea of a political conspiracy against the Countess. His argument made the loan Francis gave to King Matthias II more important to Bathory's life than previous authors, since the debt made the crown politically interested in her downfall. An additional reason to seek out her downfall was her relation to Gabor Bathory, King of Poland. McNally rejected the idea that she was targeted by Matthias because of her religion, since the church give up the chance to question her about witchcraft. ${ }^{20}$ He also established that there was a family

\footnotetext{
${ }^{16}$ McNally, Dracula was a Woman, 13.

${ }^{17}$ McNally, Dracula was a Woman, 29.

${ }^{18}$ McNally, Dracula was a Woman, 29-30.

19 Thorne, Countess Dracula, 87; Craft Infamous Lady, 30-31.

${ }^{20}$ McNally, Dracula was a Woman, 61, 79.
} 
agreement to protect her person and property, but did not successfully connect this with the inconsistent application of legal procedure in her case. ${ }^{21}$ Instead he claimed that the reasons for her arrest were unknown while at the same time maintaining that Thurzo had enough evidence to convict her, despite, as later authors noted, a majority of the evidence being hearsay or gossip. ${ }^{22}$ Like Penrose, McNally used primary sources, such as the testimony given by the accomplices, but which source correlated with which evidence was up to the reader to guess, making his entire book questionable, confusing, and impossible to confirm. Additionally, most of his bibliography was not about Bathory, but rather Dracula, vampire legends, and werewolves. While he identified an intriguing political twist to Bathory's story, his book was far more successful at dragging Bathory back to the nineteenth century plays and stories which labeled her a vampire than providing the academic community with motivation to regard her case seriously.

While McNally favored a political conspiracy, Tony Thorne preferred one based on gender. He was far more successful in providing useful information about Bathory for English readers. Thorne's book, Countess Dracula: The Life and Times of the Blood Countess, written in 1997 was the first English academic source for Bathory since McNally. Before this, Hungarian readers were able to read the work of Irma SzadeczkyKardoss, who in 1993 wrote her dissertation on Bathory and her trial. ${ }^{23}$ Because of the timing of his work, Thorne was able to interview Szadeczky-Kardoss and disseminate in his book her main argument. In essence, she took the position of defense counsel for the Countess and found that the case against Bathory had nearly no evidence, suggesting that

\footnotetext{
${ }^{21}$ McNally, Dracula was a Woman, 72.

${ }^{22}$ McNally, Dracula was a Woman, 29.

23 Thorne, Countess Dracula, 188.
} 
she would have been acquitted in a modern court room, if not found innocent. ${ }^{24}$ Her work can still be found as a reference for popular blog and online article entries. Most of these articles follow a particular theme, the example of the Countess as a much maligned historical figure who was the victim of a foreign king and a sexist environment. What changes between the online articles is merely the degree to which they support the foreign king or sexism. But why would any nation want to be tied to her, and why make such an effort to redeem her?

For Hungary, reclaiming the Countess has several nationalistic elements; first of all, right now a few countries may lay claim to her because of shifting boarders over the centuries: Slovakia, where Castle Cjesthe was; Romania, which was the seat of the senior branch of the Bathory house when it was the Principality of Transylvania; and of course Hungary, with which she identified ethnically and linguistically. Because of the questions regarding her guilt and the possibility that she was the victim of a political conspiracy, Bathory was romanticized as a possibly redeemable figure who may be connected with her national hero husband in a positive light. Since the establishment of an agreed history as well as historical figures that shape the character of a nation are vital to a nation's culture, the competition to claim the Countess is understandable. Even if she was not redeemed, her legend draws in tourists, which has always been an economic bonus.

As well as giving insight into Hungarian perceptions of Bathory, Thorne's work stood on its own to significantly place the Countess within the realm of scholarly inquiry; Countess Dracula did more to make Bathory's case a viable subject within Western academia than any of the other later works combined -- despite his assertion that his book

\footnotetext{
${ }^{24}$ Thorne, Countess Dracula, 188.
} 
was never intended to be a scholarly work. Thorne himself has become a professor at King's College on the subject of linguistics, so perhaps his comments that Countess Dracula was not intended to be a scholarly book should be interpreted as his acknowledgment that he was not a historian or anthropologist, which impacted his methodology. Not only is his bibliography a veritable "who's who" of primary texts, but each step of his research could be followed thanks to extensive footnoting, which was lacking in Penrose and McNally as well as the still to be discussed work of Craft. His was the first English language source that analyzed in depth the methodology of the trial of the accomplices and the family agreement that kept the Countess out of criminal court. His work successfully isolated and even offered explanations for deviations in the case against Bathory, connecting them back to the family agreement far more successfully than McNally.

Like McNally, Thorne identified a conspiracy, only his was based on gender, not politics. Thorne argued that Bathory was targeted not because of her crimes, but rather because she was a powerful widow. ${ }^{25}$ A woman who controlled her own resources, and was well connected internationally, was seen as a threat to the stability and power of the House of Hapsburg and Hungary. ${ }^{26}$ There was no concern about witchcraft, vampirism, or lycanthropy from the men in power; according to Thorne's argument, the threat was her place as a powerful, wealthy widow. While Thorne did discuss aspects of witchcraft that related to the Countess, the only part of his work that tied Bathory to vampires or werewolves was the title. In many ways his argument was successful, for he included letters and missives relating to Bathory not previously translated into English and

\footnotetext{
${ }^{25}$ Thorne, Countess Dracula, 12.

${ }^{26}$ Thorne, Countess Dracula, 141.
} 
published. It was not just her letters, but also the letters of Thurzo and Matthias. This meant that Thorne was able to write a significantly more in depth discussion of the Countess' early life, but he was also able to paint in broad strokes the sort of life the Countess lived as a noble woman in Hungary. This wider point of view helped support the powerful woman image so vital for Thorne's argument since it truly highlighted the vast and various estates and resources Bathory had at her command.

Despite the many laurels Countess Dracula can rest on, Thorne relied far too heavily on Western European norms of gender construction and witchcraft trials for his work. The result was undue support for the conspiracies against her based on her status as a wealthy widow. Although he worked with a plethora of primary sources, through the help of translators, he used almost no secondary sources to help place the information he used into the proper Eastern context. Not only did this mean that he imported largely French ideas about the fear of a woman in power, but it also limited how he understood the duties of a Hungarian noble woman. As a result he concluded that the case against Bathory was flimsy, but did not entirely matter because the men in charge purposefully marginalized her.

The use of translators did afford him the opportunity to use Bathory sources not effectively utilized or discovered in previous works; however, his over-reliance on those same sources resulted in too much focus on the perceived weakness of women, and also led to the interpretation of Early Modern laws from others and not from his own research. Admittedly, there may have been a linguistic barrier since the Tripartitum, the laws which governed Hungary in general and the nobility in particular, was in Latin and there was no available English translation until 2005. Despite not being able to read it directly, 
Thorne was able to present a significant discussion on the structure and focus of the Hungarian legal code. He was able to compare Bathory's case to Hapsburg family courts used to remove socially or politically embarrassing family members from power. ${ }^{27}$ These discussions were not based on his own research, but on the ideas and suggestions of other scholars and researchers he worked with.

Thorne relied very heavily on the legal opinion of Szadeczky-Kardoss for his interpretation of the standard legal practices. She claimed to be completely unable to create a case for the prosecution against Bathory, even though McNally argued there was enough evidence to convict her, and Thurzo had prepared a case against her for trial just in case. Why then was a trained lawyer, like she, unable to construct a possible argument as a prosecutor against Bathory? Her inability appeared more as unwillingness, but Thorne took her at her word. ${ }^{28}$ Whether due to bad translations or poor advice, Thorne's work regarding the legal analysis has significant holes, and conflicts with the actual Tripartitum.

The most recent English language, research based, non-fiction work, Infamous Lady: The True Story of Countess Erzabet Bathory, was a stunning example of social media triumphing over peer-reviewed publishing. While McNally argued there was a political conspiracy, and Thorne argued one based on gender, legal researcher Kimberly L. Craft argued there was both a gender and political conspiracy against the Countess. ${ }^{29}$ Craft read anything and everything, including fiction, regarding the Countess to compile her self-published book. Able to read Hungarian and Latin, Craft did not rely on

\footnotetext{
${ }^{27}$ Thorne, Countess Dracula, 128.

${ }^{28}$ Thorne, Countess Dracula, 181.

${ }^{29}$ Craft, Infamous Lady, 124.
} 
translators while still providing in depth information on the Countess' personal life. She focused on Bathory's role as a wife and mother more than the crimes and allegations of insanity. By digging into records of births and deaths, Craft was able to discredit the rumor that Bathory had an illegitimate child and, like Thorne, found very little evidence to suggest that the marriage between Elizabeth and her husband was anything but respectful. ${ }^{30}$ Craft emphasized that in the first ten years of her marriage, there was no evidence to indicate that Bathory would become one of the greatest serial killers in history. ${ }^{31}$ The willingness to dig through records unused by previous writers to debunk or discredit myths surrounding Bathory was the greatest strength of Craft's work. She refuted several myths about the Countess including allegations of madness in the family, extra-marital affairs, and the accusation that the Countess was a cold and distant mother. $^{32}$

Craft also included the translated trial documents and several letters in the appendix of her book. With this source material available in print and in English, scholars unable to read Hungarian are now able to analyze the transcripts rather than rely on secondary interpretations. Additionally, Craft re-excited the imaginations of enthusiasts with speculative suggestions regarding the motive for the Countess, most notably an anxiety disorder which caused her to lash out. Her argument was based on the conjecture that the Countess tortured more during times of stress, such as traveling or hosting parties. ${ }^{33}$ Like all other suggestions regarding the unknowable "why" of her actions, the

\footnotetext{
${ }^{30}$ Craft, Infamous Lady, 41.

${ }^{31}$ Craft, Infamous Lady, 44.

${ }^{32}$ Craft, Infamous Lady, 53.

${ }^{33}$ Craft, Infamous Lady, 76, 86.
} 
anxiety disorder was purely speculation, but it has been popularly received even if it was psycho-history.

Unfortunately readers simply have to take Craft's word that the information she gives was actually in any of the primary sources she used because unlike Thorne, her research could not be followed due to a complete lack of citation. Therefore the reader can not be sure how or why Craft was able to make the conclusions she did, such as when she claimed that Bathory suffered from epilepsy and migraines. ${ }^{34}$ That Craft included novels as part of her research also made it difficult to distinguish when she was using information from primary or secondary sources, and when she was extracting imagery from novels. Like Thorne, Craft also focused too much on Bathory sources and did not make proper use of the secondary sources she had available - although the lack of citations makes this difficult to prove. Unlike Thorne, Craft's bibliography contains a number of secondary sources, many of which were used in this thesis. Craft, however, did not use these sources to the extent needed to put Bathory's legend into historical context - particularly in regards to gender and legal procedures. Indicative of her lack of use of historical context sources, the Tripartitum was not used. Her claim to read Latin suggests that Craft could have used the original text, though the translated version was also accessible. Despite this, the law code does not appear in her work. ${ }^{35}$

The final type of Bathory text has several echoes of the first type, but with enough differences that it deserves its own mention: true crime. The authors of this genre often based their work on the older, folklore-based stories and perpetuate the myths of blood

\footnotetext{
${ }^{34}$ Craft, Infamous Lady, 13.

${ }^{35}$ Penrose, McNally, Thorne, and Craft, as the main English, research supported, sources will form the backbone of the Bathory sources within this thesis and will collectively be known as the Enthusiasts for the remainder of this work.
} 
bathing and sexual sadism. Their main focus, however, was Bathory's place as the first known female serial killer. For true crime writers, Bathory has been a truly enigmatic example of women killers. Unlike other female killers, she did not kill as a result of revenge, money, or "battered wife syndrome." ${ }^{36}$ She also did not employ traditionally female techniques of killing such as poison. ${ }^{37}$ Her more hands-on, physically violent style has much more in common with male twentieth century serial killers than with fellow female serial killers, especially if sexual sadism has been accepted as a motivation for the Countess. $^{38}$

True crime writers do not offer anything particularly new to the study of Bathory, rather she added something new to the study of true crime. Among feminist writers on crime, there was an argument that female killers were pushed into committing their crimes because of the pressures of society. ${ }^{39}$ Bathory, by being socially elevated as a noble, very neatly countered that argument. Although she may have been stopped by a conspiracy, there was no identified social pressure on her supported her drive to kill.

The subject of the social pressures on women, particularly regarding a powerful woman in Early Modern Europe was an important element to the Bathory case. The Enthusiasts, the collective name for Penrose, McNally, Thorne, and Craft for this thesis, all believed to one degree or another that Bathory's place as a wealthy woman frightened

\footnotetext{
${ }^{36}$ Michael D. Kelleher and C.J. Kelleher, Murder Most Rare: The Female Serial Killer (Westport: Praeger Publishers, 1998), xi; Kerry SeGrove, Women Serial and Mass Murderers: A Worldwide Reference 1580 through 1990 (Jefferson: McFarland and Company, 1992), 1-2; Peter Vronsky, Female Serial Killers: How and Why Women Become Monsters (New York: Berkley Books, 2007), 6, 23, 78; Robert Hole and Anthony Bolin, "The Female Serial Killer," in Contemporary Perspectives on Serial Murder ed. Ronald M. Holmes and Stephan T. Holmes (Thousand Oaks: Sage Publications, 1998), 45.

${ }^{37}$ Vronsky, Female Serial Killers, 42; SeGrove, Female Serial, 1.

${ }^{38}$ SeGrove, Female Serial, 20-22; Vronsky, Female Serial Killers, 78.

${ }^{39}$ Kelleher, Most Rare, xi; SeGrove, Female Serial, 2-3; Vronsky, Female Serial Killers, 6.
} 
or unnerved the king and the palatine and pushed them to remove her from power. ${ }^{40}$ Indeed the acceptability of women in power has been a subject of furious debate since women's history became a recognized field in the 1970s. The subject has become heated enough that some authors, namely Joan Kelly-Gadol, argued that women were excluded from the Humanist benefits of the Renaissance and that when dealing with women's history, a whole different historical timeline must be created. ${ }^{41}$ On the surface, the argument worked. Although the Humanist ideals of science, education and classical learning were open to men, they were closed to women who were not allowed to attend institutes of higher learning. ${ }^{42}$ The Protestant Reformation, which was particularly strong in Central and Eastern Europe, closed nunneries and convents which had been used as a viable alternative for women who did not, or could not, marry. ${ }^{43}$ Now for many women the only option for a future, put glibly, was to get married, make babies, and feed everyone until the day she died.

Kelly-Gadol may have been correct that the Renaissance did not significantly change the position of women, but it did not change the position of life for most of Europe either. The Renaissance was an elite male phenomenon, but it was not an era when women were ignored. In fact the debate about women, including their proper roles regarding leadership, ranged from the realistic to the absurd, and the discussion of the

\footnotetext{
${ }^{40}$ Craft, Infamous Lady, 117-118; Thorne, Countess Dracula, 141; McNally, Dracula was a Woman, 60; Penrose, Bloody Countess, 161.

${ }^{41}$ David Herlihy, "Did Women Have a Renaissance? A Reconsideration" in Women, Family and Society in Medieval Europe: Historical Essays 1978-1991 ed. David Herlihy (Providence: Berghahm Books, 1995), 33; Dolen, "Gender and Sexuality in Early Modern England," 7. Joan Kelly, "Did Women Have a Renaissance?" in Women, History And Theory: The Essays of Joan Kelly ed. Joan Kelly (Chicago: Chicago University Press, 1984), 19-50.

${ }_{42}$ Pavla Miller, "Gender and Education before and after Mass Schooling," in A Companion to Gender History ed.Teresa A. Meade and Merry E. Wiesner-Hanks (Molden: Blackwell Publishing, 2004), 130; Fairchilds, Women, 14, 48; Bogucka, Women in Early Modern Polish Society, 123, 125.

${ }^{43}$ Fairchilds, Women, 198.
} 
place of women was motivated by two very important aspects of the Early Modern Era: the growth of court society and many states being ruled by women during the time.

The work of authors such as Merry Weisner and Lisa DiCaprio, as well as a plethora of others, began to question the conclusion of Kelly-Gadol, particularly in the areas of women's education and the perception of women in power. The general conclusion with this new wave of women's history was that while women did not benefit directly from the Renaissance, it was not stagnate either. The lack of formally educated women was not based on the belief that women were stupid, but that in all but the most elite cases, education was perceived as a waste of their time and energy since it would never be used. ${ }^{44}$ When it came to women in charge, this too was less frightening to men than certain sources have suggested. For the common man, taking orders from the lord's wife was expected. ${ }^{45}$ For all but the most bigoted of nobles, having in depth discussions with a woman about politics, religion, or social issues, was the norm for court life. ${ }^{46}$ Sources from the Early Modern era which claimed that women were monsters have been labeled as satirical or an extreme minority opinion. ${ }^{47}$ For the majority of men, a wife may have been legally considered property but was functionally a partner who was able to carve out her own sphere of power and influence if she was clever and had the courage of her conviction. ${ }^{48}$ Early Modern Europe was by no means an equal society, but the work

\footnotetext{
${ }^{44}$ Miller, "Gender and Education,"130.

${ }^{45}$ Bogucka, Women in Early Modern Polish Society, 161.

${ }^{46}$ Madean, Renaissance Notion, 64; Fairchilds, Women, 22-23.

${ }^{47}$ Bogucka, Women in Early Modern Polish Society, 80-81; Madean, Renaissance Notion, 12.

${ }^{48}$ Meade and Hanks, Companion to Gender, 65; Fairchilds, Women, 78.
} 
of Weisner, DiCaprio, and others who offer a reconsideration of contemporary sources, have depicted it as a much less phallo-centric one. ${ }^{49}$

Since the Bathory case has also centered on the use (or abuse) of legal justice systems, current theories on the Early Modern judicial system must also be discussed. The growth of literacy and availability of education as well as the solidification of borders resulted in a growth of bureaucracy. This also meant a shift from the accusatory system of justice to the inquisitional system. ${ }^{50}$ This system made the social standing of witnesses and accused criminals became far more important to the outcome of a trial than previously. Most of the trial records that historians used to understand the inquisitorial system, particularly torture, came from the West, France specifically. ${ }^{51}$ While this meant limited application to Eastern and Central Europe, it still allowed for a basis of understanding for something that has become incomprehensible to the modern mind torture.

Despite claims of mistrial, no English work applied the standards of Early Modern justice to Bathory's case, and works on Early Modern judicial systems do not mention Bathory's case. Historians such as Martyn Rady and Geza Palffy have agreed that, in the Early Modern Era, laws doubled as social controls, generally following the

\footnotetext{
${ }^{49}$ Theories about women's position within Early Modern Europe have spanned whole books in and of themselves. I have attempted to summarize the conclusions of the majority of the works here so that the reader may continue without being hampered by debunked popular understandings of women of the era. A fuller discussion of individual arguments, particularly regarding women's education and positions of power, will be handled in Chapter Three.

${ }^{50}$ Laura Stokes, Demons of Urban Reform: Early European Witch Trials and Criminal Justice, 14301530 (New York: Palgrave MacMillan, 2011), 79; Mossimo Vallerani, Medieval Public Justice, trans. Sarah Rubin Blonshei (Washington, D.C.: Catholic University of America Press, 2012 ), 4.

${ }^{51}$ Stokes, Demons of Urban, 87; Vallerani, Medieval Public, 80; Lisa Silverman, Tortured Subjects: Pain, Truth, and the Body in Early Modern France (Chicago: University of Chicago Press, 2001), 6.
} 
prescribed guidelines for the dominate form of Christianity for the country. ${ }^{52}$ This attempt at social control was also a very dark aspect of Early Modern justice. Rumors, which then became gossip, eventually reached the ears of those charged with maintaining control who then looked for evidence to support those rumors. ${ }^{53}$ The evidence may have been circumstantial, but it was sometimes enough to lead to a conviction and punishment, particularly for cases regarding fornication and pre-marital sex. At the same time, this reliance on gossip meant nobles enjoyed very different treatment before the law. Not only could they bribe their way out of trouble, but they could refute gossip from servants off hand. ${ }^{54}$ This meant that very often the Early Modern judicial system could not penalize nobles, so when it did - as in the case of Bathory - it was not a quiet event.

The power and position of women in Early Modern Europe in general, and Hungary specifically, and the function and dysfunction of the Early Modern judicial system will be discussed in relation to the Bathory case. Because women had more influence than previously believed, and because of the perception that Eastern Europe was more accepting of a woman of strong personality, it would have been very unlikely that King Matthias II and Palatine Thurzo were actually threatened by the Countess, even when she was a widow. The understanding of how truth was constructed for legal cases meant that torturing Bathory's accomplices did not invalidate the trial in any way, and a specific look at the legal code, particularly regarding noble privilege and when it can be revoked, showed that what the Enthusiasts called deviations or illegalities were actually

\footnotetext{
52 Stokes, Demons of Urban, 2; Richard McMahon, "Introduction" in Crimes, Law and Popular Culture in Europe, 1500-1900 ed. Richard McMahon (Portland: William Publishing, 2008), 7.

${ }^{53}$ Ulinka Rublock, The Crimes of Women in Early Modern Germany (Oxford: Clarendon Press, 1999), 16.

${ }^{54}$ Rublock, Crimes of Women, 22.
} 
in accordance with the Tripartitum. The family agreement was not at all intended to hurt the Bathory family or the Countess, but was created specifically to save both and, by agreeing to it, Palatine Thurzo was obeying the charge of his office and the deathbed wish of his friend, Francis Nadasdy.

But first a word regarding the sources used. Although reasonable efforts have been made, works dealing specifically with Central and Eastern Europe during the Early Modern Era are often hard to find due to lack of primary sources and lack of Western scholarly interest in Early Modern Eastern Europe over the rise and fall of Communism. ${ }^{55}$ To counter these issues, a wide net has been cast for sources, covering most of Europe and occasionally England to compare, contrast, and formulate a broader historical and social context of Early Modern Europe into which Hungarian exceptions and deviations may be included. The primary sources used for this project were the most widely read and discussed during the sixteenth century, ensuring a greater likelihood that the Countess and her contemporaries in Hungary read, discussed, and been influenced them. Most of the sources have not focused specifically on Bathory herself, because the goal is to look at the investigation against her and the trial of her accomplices in a wider social and historical context, rather than writing another biographical account. As a result, there are times when Bathory herself is more consequential than a focal point of discussions. This was done with intention to reveal the extreme degree of normality in her personal

\footnotetext{
${ }^{55}$ For Hungary in particular, primary sources before 1526 are hard to find because there was a massive lose of records. After hearing of Louis II's death, his wife loaded all the archives from the castle on a barge to be sent to Vienna for safe keeping. The barge sank into the mud of the Danube and took the archives with it. Equally problematic, no archives were kept for lost noble homes. If a noble house died, its records were not preserved. All of this is further exacerbated by the natural lose of information due to war and other natural disasters, for which Hungary was a familiar stage. Martyn Rady, Nobility, Land and Service in Medieval Hungary (New York: Palgrave Publishers, 2000), 9.
} 
life, specifically her roles as wife and mother, and her interaction with political and legal authority.

The investigation of Bathory and the trial of her accomplices were used by previous authors to promote gender and legal conspiracies against the Countess, the facts of which will also be addressed. Because of these conspiracies, any discussion of the legal procedures against Bathory must also include contextual information on women as well as the Early Modern judicial systems. Therefore, this thesis covers two topics that do not unify well: gender perceptions and expectations, and legal procedures. The organization of the chapters attempts to make the shift in topic as organic as possible. The first chapter provides a historical and biographical background for those unfamiliar with the case of Bathory or late sixteenth century Hungary. Readers looking for fantastic revelations regarding her life or her crimes will be disappointed, chapter one provides nothing more than a working foundation. The following two chapters are part one and part two of the same idea: womanhood and family in Early Modern Europe. Those particular topics have spanned books on their own. Chapter two discusses early modern children and child rearing, focusing on the surprising lack of gendering in the first ten years of life. Bathory's childhood was blamed by previous authors as being cruel and overindulgent, and used as an explanation of her crimes. Because of her own upbringing, Bathory raised her own children in a cold and distant environment, preferring her own sadistic pleasures to her duties as a wife and a mother. Chapter two takes exception to these theories with housekeeping records, letters, diaries, and archeological evidence indicating how loved and precious children were to noble families, and the various ways in which that love was shown. This chapter concludes that Bathory's own childhood, and 
the care which she gave to her children, were quite typical and not at all cold, distant, and contained few moments where she or her daughters, were ill treated for being "only girls."

The gendering process in Early Modern Europe is the subject of chapter three, with particular focus on the role of women in aristocratic families. Arguments of conspiracy based on Bathory's status as a wealthy widow require that women and femininity were regarded as dangerous or wrong. It requires that Bathory spent her entire married life in subjugation and subservience; that she, and by extension all aristocratic women, had no rights, privileges, and - beyond child bearing - duties. Chapter three discusses the various ways in which the gender conspiracy is false. While the rights and privileges of women varied from nation to nation in Early Modern Europe, Hungary's reoccurring role as a theatre of devastating wars necessitated that women shouldered duties that their Western counterparts did not. Bathory ran, nearly entirely on her own, the lands and estates for her husband while he was at war, and she was not alone. Hungarian noble women often held land and properties, and there were various, legal, ways by which they obtained them. Additionally, the growth of court life and the acceptance of a more equalizing medical theory allowed for appreciation and acceptance of the witty, educated, woman Bathory was supposed to be. Between these two chapters, the gender-based conspiracy becomes erroneous and fantastical.

Chapter four starts to bridge the gap between gender and judicial by covering the normal sorts of crimes and penalties women experienced in Early Modern Europe, as well as how female-perpetrated crimes have evolved over the past four centuries. With a few notable exceptions, there was little changed about methods, targets, and motives of 
female criminals, particularly regarding murder. This chapter accepts the label of Bathory as a serial killer, and examines her murders within the norms of female crime, both past and present, and the Early Modern Europe codes of violence. Bathory's atrocities, still just as shocking today was it was four centuries ago, none the less followed the gendered conceptions of female violence far more often than they countered them. Chapter five carries the judicial discussion forward by getting into the nitty-gritty of Early Modern judicial procedures and duties, with special attention to torture. The use of torture to gain confessions from Bathory's four accomplices was used to support the failure of justice in her case. However, the Early Modern understanding of judicial truth and the procedures of Early Modern justice negate this belief. The use of judicial torture, twisted by the witch hunts and attacks on heresy, is defined, reexamined, and outlined within chapter five. Chapter five also examines the customary laws of 1600 Hungary to determine if Bathory's rights and privileges as a noble were violated by Thurzo's investigation. A little examined loophole from the customary laws, and a closer examination of Hungarian judicial procedures absolves Thurzo of violations regarding specific aspects of his investigation. While not entirely by-the-book, chapter five concludes that Thurzo's use of torture and his investigation of Bathory's crime without prior notification to the Countess were both legal.

Finally, although all the chapters tie into Bathory, chapter six brings the spotlight more tightly on her case and brings historical context to some of the most baffling elements of her life. The Bathory family's long history of mental illness was used to explain some of the Countess' behavior, but there was only speculation regarding what and how she suffered. Chapter six examines the Early Modern elite understanding of 
mental illness, and some of the recommended treatments - some of which did include the consumption of blood. Often painted as misogynistic villains, chapter six also examines the actions of King Matthias II and Palatine Thurzo regarding Bathory. While Matthias's motivations may have been less than honest, his repeated demands for a formal trial against Bathory on the charge of murder negate accusations of conspiracy regarding the debt, or an attempted land grab. Thurzo, put in an awkward position in Bathory's case, made the best of a bad situation by making an agreement with the family that while perhaps not legal in the strictest sense, made for a far better outcome than a trial. Finally, chapter six examines the potential outcomes of Bathory's trial, using the multiple trials of her Transylvanian cousin, Anna Bathory, and the legal back and forth of Joanna I of Spain as precedent. The ultimate conclusion of this thesis is that there was no conspiracy against Bathory based on gender or politics, Thurzo's investigation and application of procedure were all legal, and placing her under house arrest while avoiding a trial was the best possible outcome of a terrifying situation 


\section{CHAPTER I}

\section{THE INFAMOUS BLOODY COUNTESS DRACULA:}

\section{THE BIOGRAPHY OF COUNTESS}

\section{ELIZABETH BATHORY}

Even 400 years after her death, questions still remain about how many girls were killed, and what her motives for killing them were. Enthusiasts, particularly Craft and Thorne, argued the Countess was falsely charged and speculated that Thurzo and Matthias began a conspiracy against her to gain control of her land and negate a debt. All the questions surrounding her investigation can be boiled down into one, all encompassing, inquiry: were the noble rights and privileges guaranteed to Bathory by the Tripartium violated in her investigation? What can be known, but so far has not been studied, deals directly with this question. It requires knowledge well beyond the basic biography of Bathory, delving deep into the roles of noble women, their place within society, and the Early Modern judicial system. But the first step is the biographical basics of Bathory, including how her investigation was handled, the details of the family agreement, and her ultimate end. ${ }^{56}$

\footnotetext{
${ }^{56}$ This chapter will provide only a bare-bones biography to assist readers in understanding the rest of this thesis. Readers looking for more details or specifics are encouraged to read the works of Valentine Penrose, for details of her crimes, Kimberly Craft, for a more detailed biography, or Tony Thorne, for details on her investigation.
} 
The foundation for Elizabeth Bathory's investigation was laid forty-six years before the Countess was born. In 1514, an anti-feudalist uprising spread across Hungary. Peasants sought to better themselves and free themselves from serfdom, much the same way peasants in Western European nations had. ${ }^{57}$ The revolt was an utter and complete failure; it was put down quickly and its leader was executed. ${ }^{58}$ However, the revolt encouraged the passing of the Hungarian legal code, generally known as the Tripartitum, in 1517. This code took the Golden Bull, the Hungarian Magna Carta, and expanded it to clearly define the rights and privileges of nobles, legal procedures, and the few rights and privileges of serfs. ${ }^{59}$ The latter were significantly reduced as punishment for the 1514 revolt, on top of any penalties nobles enacted locally. Because it promoted the power of the nobles and often regarded peasants and serfs as resources rather than people, the Tripartitum would actually protect many of Bathory's actions, but also clearly limit how far that protection went.

As the Renaissance spread through the Italian provinces and into Western Europe, Hungary experienced a dramatic shift in fortunes that affected its place in Europe for centuries and created an environment of nearly absolute noble power, which Bathory took full advantage of. For much of the Middle Ages, Hungary was well enmeshed in the social, political, and religious events of the rest of Europe. Its position as the breadbasket of Europe as well as its significant mineral wealth meant that it was fully able to

\footnotetext{
${ }^{57}$ Norman Housley, Religious Warfare in Europe 1400-1536 (London: Oxford University Press, 2002), 70.

${ }^{58}$ Miklos Molnar, A Concise History of Hungary (Cambridge: Cambridge University Press, 2001), 82.

${ }^{59}$ Oksana Buranbaeve and Vanja Mlandino, Culture and Customs of Hungary (Santa Barbara: Greenwood Press, 2011) 25; Laszlo Peter, ed. "The Irrepressible Authority of the Tripartitum," in The Customary Law of The Renowned Kingdom of Hungary in Three Parts Stephen Werboczy trans. Janos M. Bak, Peter Banyo, and Martyn Rady (Budapest: Central European University, 2005), xiii; Thorne, Countess Dracula, 21.
} 
participate in international trade. ${ }^{60}$ Over the course of the Middle Ages Hungary's kings and queens counted members of the royal courts of France, Poland, Russia and the Germanic states among their closest kin. ${ }^{61}$

By 1526, however, this close knit association had changed and Hungary was seen as falling behind the rest of Europe, particularly socially and economically. Hungary was unable to take advantage of the New World market, which brought in new foods like potatoes and corn and reduced the need for Hungarian cereal grains. The New World also flooded the precious minerals market, making the silver and copper mines in the Carpathians valuable locally, but unable to realistically compete internationally. ${ }^{62}$ Additionally, Hungary was unable to begin the process of industrialization because the Ottoman conquest, partition of the country, and the Hapsburg annexation caused the nobles to turn to self-sufficiency based on serf-worked agriculture while Western Europe restructured its societies and were in the infant stages of capitalism. ${ }^{63}$ While Western Europe was reducing its reliance on serfdom in exchange for paid labor and investing in

\footnotetext{
${ }^{60}$ Peter F. Sugar, "Introduction," in A History of Hungary ed. Peter F. Sugar, Peter Hanak, and Tibor Frank (Bloomington: Indiana University Press, 1990), xi; Vera Zimanyi, Economy and Society in $16^{\text {th }}$ and $17^{\text {th }}$ Century Hungary (1526 - 1650) (Budapest: Ahademiai Kiado, 1987), 17-18; Martin Fumee, Historie of the Troubles of Hungarie: Containing the Pitifull Losse and Ruine of that Kingdome, and the Warres Happened there in that time, betweene the Christians and Turks trans. R.C. Gentleman. (London, 1600), 34, 11; Geza Palffy, The Kingdom of Hungary and the Hapsburg Monarchy in the Sixteenth Century trans. Thomas J. and Helen D. DeKarnfeld (New York: Columbia University Press, 2009), 18.

${ }^{61}$ Palffy Kingdom of Hungary, 18.

${ }^{62}$ Laszlo Kontler, A History of Hungary: Millennium in Central Europe (New York: Palgrave Macmillan, 2002), 160.

${ }^{63}$ Katalin Peter, "The Later Ottoman Period and Royal Hungary 1606-1711" in History of Hungary, Sugar, Hanak, and Frank, 107. Bryan Cartedge, The Will to Survive: A History of Hungary (New York: Columbia University Press, 2011), 98; Zimanyi, Economy and Society, 30.
} 
urban growth, Hungary enacted further restrictions on its serfs and stayed with large estate farms, keeping cities small. ${ }^{64}$

The year 1526 and the Battle Mohacs was the turning point for Hungary. The Turkish victory at this battle solidified the Ottoman conquest of an enormous swath of Hungary, and was the site of the death of the twenty-year old king, Louis II. ${ }^{65}$ The aftermath of the battle had ramifications for Bathory's case. For nearly three centuries, Hungarian nobles elected the king through the Diet rather than default immediately to primogeniture. ${ }^{66}$ After Louis II's death was confirmed, the Diet once again met to elect a new king, and Louis had no son to guide the direction of the Diet's votes. In a strange and complicated series of laws and voting rounds, two kings ended up being legally elected and crowned: John Szapolyai, whose power base was from Transylvania, and the Hapsburg prince Ferdinand I, who claimed the Hungarian throne because Louis II was his brother-in-law. ${ }^{67}$ Since traditionally kings do not like sharing power, particularly with someone who was trying to claim the same title, civil war erupted between John and Ferdinand. By 1527, John, unable to counter the wave after wave of Germanic mercenaries Ferdinand threw against him, was routed back to Transylvania and then forced to seek shelter from his father-in-law in Poland. ${ }^{68}$ John was not yet ready to accept a Hapsburg on the Hungarian throne. In 1528 he signed a treaty with the Ottomans for

\footnotetext{
${ }^{64}$ Peter, "Later Ottoman", 107; Oksana Buranbaeve and Vanja Mlandino, Culture and Customs of Hungary, 25; Zimanyi, Economy and Society, 37.

${ }^{65}$ Fumee, Historie, 31.

${ }^{66}$ Ferenc Szakaly, "The Early Ottomen Period, Including Royal Hungary, 1526-1606," in History of Hungary, Sugar, Hanak, and Frank, 91; Palffy, Kingdom of Hungary, 161-162; Sugar, "Introduction," xi.

${ }^{67}$ Szakaly, "Early Ottomen," 83; Cartedge, Will to Survive, 81; Fumee, Historie, 38-39; Palffy, Kingdom of Hungary, 38; Kontler, History of Hungary, 139. It is interesting to note that Elizabeth's ancestor, Istvan Bathory, campaigned for Ferdinand. Palffy, Kingdom of Hungary, 39.

${ }^{68}$ Kontler, History of Hungary, 139; Cartedge, Will to Survive, 82; Fumee, Historie, 42.
} 
military and financial support against Ferdinand. ${ }^{69}$ For the first ten years of his reign, Ferdinand was forced to fight the Turks on one hand, and John's forces on the other. Hungary was involved in not only a territorial war, but also a civil war at exactly the same time.

The civil war ended first. In 1538, Ferdinand and John signed a secret treaty which stated that, whether he had a son or not, John considered Ferdinand his heir and therefore the true King of Hungary. ${ }^{70}$ This was agreeable to both men: John would die still being able to claim the title of King of Hungary, and Ferdinand no longer had to waste time and energy fighting John, because he would inherit anything John had anyway. In 1540, John I was blessed with a healthy, happy, baby boy; nine months later, John I died. ${ }^{71}$ Nearly immediately the Transylvanian barons, supported by John I's wife, named the infant boy John II and placed the crown on his head in violation of the 1538 treaty. ${ }^{72}$ When Ferdinand pressed his claim to the Hungarian throne, the Ottomans, who believed the regents of John II meant to continue John I's alliance, were shocked and a little betrayed. However, by 1541 they had control of Buda which put them in a unique position to finally settle the royal debate. ${ }^{73}$ Hungary was officially divided into three parts. The north and west was Ferdinand's territory and became known as Royal Hungary. The central plains were held by the Ottomans, and the Principality of

\footnotetext{
${ }^{69}$ Kontler, History of Hungary, 140; Szakaly, "Early Ottoman," 84; Cartledge, Will to Survive, 82; Fumee, Historie, 42;

${ }^{70}$ Kontler, History of Hungary, 140; Szakaly, "Early Ottoman," 85; Cartledge, Will to Survive, 83; Fumee, Historie, 57; Palffy, Kingdom of Hungary, 45-46.

${ }^{71}$ Kontler, History of Hungary, 141-142; Szakaly, "Early Ottoman," 85; Cartledge, Will to Survive, 83; Fumee, Historie, 57-58; Palffy, Kingdom of Hungary, 46.

${ }^{72}$ Kontler, History of Hungary, 141-142; Szakaly, "Early Ottoman," 85; Cartledge, Will to Survive, 83; Fumee, Historie, 57-58; Palffy, Kingdom of Hungary, 46.

${ }^{73}$ Kontler, History of Hungary, 141-142; Szakaly, "Early Ottoman," 85; Cartledge, Will to Survive, 83; Fumee, Historie, 57-58; Palffy, Kingdom of Hungary, 47.
} 
Transylvania was given to John II, for which he paid the Ottomans 1,000 florins annually to keep. ${ }^{74}$ For the rest of Ferdinand's reign, there were infrequent attempts to unite Transylvania and Royal Hungary, but they all failed and eventually the idea was abandoned. The Bathory family was divided by this split. The family seat was in Transylvania, but the family also had a basis of power in Royal Hungary. ${ }^{75}$ Elizabeth Bathory was born, lived, and prospered in Royal Hungary and had little interest in her relations in Transylvania.

The Protestant Reformation entered Hungary significantly more peacefully than it did the rest of Europe. The appeal of Protestantism for Hungarians was much the same as it was for the rest of Europe - sermons in the vernacular provided answers to a very troubled and anxious country. Obeying the pope and the Catholic faith had not stopped the Ottomans from taking over, and the hope in the country was that keeping the Protestant faith would save them. ${ }^{76}$ Royal Hungary's official policy against Protestantism was persecution, but the law did not follow the reality. ${ }^{77}$ This was particularly true as the most powerful families in Hungary, including the Bathory and the Nadasdy families, converted to various branches of Protestantism. Since the Hapsburgs needed to maintain a buffer zone between the Holy Roman Empire and the Ottoman Empire, Protestantism and most of its branch faiths were allowed in Royal Hungary to keep the support of the powerful nobles by $1560 .^{78}$

\footnotetext{
${ }^{74}$ Palffy, Kingdom of Hungary, 47.

${ }^{75}$ McNally, Dracula was a Woman, 18-19; Penrose, Bloody Countess, 14.

${ }^{76}$ Szakaly, "Early Otttoman," 94.

${ }^{77}$ Kontler, History, 152; Cartedge, Will to Survive, 85.

${ }^{78}$ Szakaly, "Early Ottoman," 93; Cartedge, Will to Survive, 99-102
} 
On August $7^{\text {th }}, 1560$, Elizabeth Bathory was born. Her parents were cousins, her father from the Ecsed branch of the family, and her mother from the Somolyo branch. ${ }^{79}$ She was the second child of the couple, preceded by a son and followed by two daughters. As Calvinists, the family invested in an education for all their children. Bathory was taught a variety of languages, including Greek and Latin, and was given an education based in the Classics. ${ }^{80}$ She also enjoyed horse back riding, reading, and playing dress up. ${ }^{81}$ For Royal Hungary, this childhood was typical of the aristocracy.

Despite the Ottoman invasion and the civil war, Royal Hungary continued to maintain some connection with the rest of Europe which allowed the denizens to participate in the Renaissance. Italian art and architecture were imported and used in the castles of nobles, while at the same time libraries and literacy spread. ${ }^{82}$ The Nadasdy family in particular took full advantage of this. Sarvar, the family seat, was redesigned by Italian architects and Francis was given a Humanist education. ${ }^{83}$ Nobles took pride in hosting eminent scholars as patrons, just as in Western Europe. The Nadasdy family hosted authors who published the first Hungarian grammar book and translated the Bible into Hungarian. $^{84}$

In 1570 , the Bathory family approached the Nadasdy family with an offer of marriage. Francis, at fifteen and doing well during his time at the Viennese court, was offered the chance of marriage to Elizabeth. The offer did not mean marriage

\footnotetext{
${ }^{79}$ McNally, Dracula was a Woman, 16, 18-19; Penrose, Bloody Countess, 15; Craft, Infamous Lady, 4; Thorne, Countess Dracula, 84.

${ }^{80}$ Thorne, Countess Dracula, 84; McNally, Dracula was a Woman, 19; Penrose, Bloody Countess, 15; Craft, Infamous Lady, 14.

${ }^{81}$ Craft, Infamous Lady, 15.

${ }^{82}$ Sugar, "Introduction", xii; Kontler, History, 153-154.

${ }^{83}$ Craft, Infamous Lady, 29.

${ }^{84}$ Kontler, History, 155; Thorne, Countess Dracula, 91.
} 
immediately, but rather gave Francis the first choice if he wanted her. ${ }^{85}$ The match was found to be beneficial and Francis not only accepted first choice, but agreed to marry her. At the age of ten, Bathory had a reputation for intelligence, wit, capability, and beauty. ${ }^{86}$ The marriage did not take place until Bathory was fourteen and Francis was twenty. In the time between, Bathory was sent to Sarvar where her education shifted from the academic to the practical and she learned to manage the vast estates of the Nadasdy family. ${ }^{87}$ During this interim, she supposedly began an affair with a peasant boy and became pregnant. ${ }^{88}$ The evidence for the pregnancy, however, was only in peasant rumor well after Bathory's death and therefore unlikely. ${ }^{89}$ Illegitimate child or not, on May $8^{\text {th }}$, 1574 the two were married in a lavish, three day, festival in the presence of 4,500 guests. ${ }^{90}$ Bathory officially kept her name, as was the custom in Hungary, but was often called by her husband's last name. ${ }^{91}$

Until 1591, the couple lived a wealthy and privileged life. Like other nobles, they did not pay taxes on their lands and had the right to use the profits of their estates as they wanted without oversight. The couple built a fortune off the surplus of their farms thanks to a population boom in the rest of Europe. ${ }^{92}$ Since the partition of the country, the war against the Ottomans was done and the first thirty one years of Bathory's life was a time of relative peace and stability. There were minor conflicts between Hungary and

\footnotetext{
85 Thorne, Countess Dracula, 88-89.

${ }^{86}$ Penrose, Bloody Countess, 20; Craft, Infamous Lady, 28.

${ }^{87}$ Thorne, Countess Dracula, 89.

${ }^{88}$ McNally, Dracula was a Woman, 29; Craft, Infamous Lady, 31;Thorne, Countess Dracula, 91.

${ }^{89}$ Craft, Infamous Lady, 31.

${ }^{90}$ McNally, Dracula was a Woman, 30; Craft, Infamous Lady, 33; Thorne, Countess Dracula, 92.

${ }^{91}$ Katalin Peter, "Introduction," in Beloved Children: History of Aristocratic Childhood in Hungary in the Early Modern Age ed. Katalin Peter trans. Rachel and Janos Hideg (Budapest: Central European University Press, 2001), 17.

92 Peter, "Later Ottoman", 107; Buranbaeve and Mlandino Culture and Customs, 25; Zimanyi, Economy and Society, 37.
} 
Ottomans at the border, which Francis participated in starting in 1578, but nothing more. While her husband was gone, Bathory took over administering the estates, supporting various charities for widows and rape victims of the Ottomans, and caring for her children. ${ }^{93}$ The couple had five children, three of which lived to adulthood: Anna, Katrine, and Paul. Bathory, and her children, were not raised in a more violent environment than the rest of the Early Modern world; a tense and anxious one, certainly, but not a particularly violent one.

That changed in 1591 with yet another foreign invasion-internal conflict. The first has been called both the Fifteen Years War and the Long War, and was the final break between Hungarian culture and Western Europe. After several decades of peace the Ottomans, mostly seeking to distract people from domestic troubles, launched an invasion with the intent to conquer Vienna. ${ }^{94}$ It was during this war that Francis earned the title the Black Bey of Hungary for his apparent delight in destroying the Turks. ${ }^{95}$ The war was absolutely devastating for Hungary, causing a severe population drop, wide spread famine and epidemics, with very little to show for it in the end. In fact, despite the fifteen years of brutal combat which caused visitors to classify Hungary as a wasteland, there were no significant border changes or shift in power from the way things had been in $1591 .{ }^{96}$ For the Hapsburgs, it was actually more expensive since they had to pay the Turks 200,000 florins annually just to keep the same sliver of Royal Hungary. ${ }^{97}$ While the war was devastating for Hungary, Bathory found her coffers swelling with the

\footnotetext{
${ }^{93}$ Craft, Infamous Lady, 43.

${ }^{94}$ Kontler, History, 160; Szakaly, "Early Ottoman”, 96; Palffy, Kingdom of Hungary, 209.

95 Thorne, Countess Dracula, 95.

${ }^{96}$ Kontler, History, 160; Szakaly, "Early Ottoman", 96; Palffy, Kingdom of Hungary, 209.

${ }^{97}$ Szakaly, "Early Ottomen," 99.
} 
Ottoman treasures her husband sent back from the front. In fact, the family was doing so well they were able to provide a loan to the Hapsburg family to continue the war effort and ensure soldiers received their wages. ${ }^{98}$ This loan, however, ended up a point of contention between the Nadasdy family and King Matthias II. Francis frequently requested repayment of the loan, and his widow continued his request. At the same time, attempts by Matthias to bring Hungary back to Catholicism outraged nobles in Royal Hungary and Transylvania, resulting in the Bocskai Rebellion. ${ }^{99}$ The rebellion was only a year long, ending in 1606, and reasserted the religious freedom of Hungarian nobles. But it also left deep feelings of resentment against the Hapsburgs which never fully healed and led to another anti-Hapsburg rebellion led by Rakoczi starting in $1697 .{ }^{100}$

Because of the multiple wars, both foreign and domestic, Hungary was unable to maintain the connection with Western Europe that it had enjoyed before 1526. Its continued reliance on largely subsistence agriculture on noble held demesne farms, rather than industrialization and urbanization, also set it further back. While the wealthy nobles were able to maintain strong enough connections to the West to participate in and promote many aspects of Renaissance humanism, by 1606 there was an obvious disconnect and Hungary would lag behind Western Europe in social and economic regards between fifty and one hundred years.

All of this meant that while the first decades of Bathory's life were relatively peaceful, the years after 1591 were chaotic and confusing. Bathory suffered significant personal and economic losses that she struggled to effectively manage. The first blow

\footnotetext{
${ }^{98}$ Craft, Infamous Lady, 67; McNally, Dracula was a Woman, 60.

${ }^{99}$ Palffy, Kingdom of Hungary, 221; Szakaly, "Early Ottomen," 98.

${ }^{100}$ Cartedge, Will to Survive, 99.
} 
was in December of 1603, when her husband returned from the battle field terminally ill with an unidentified disease. On January $4^{\text {th }}, 1604$ Francis died. Before he died, he wrote to his friend, George Thurzo, asking him to watch over his widow and children when Francis died. ${ }^{101}$ This death bed request later directly clashed with Thurzo's duties as the new Palatine of Hungary, the first in Hungary since Francis’ own father died.

The death of her husband was the first misfortune to hit Bathory, the second was the death of her brother in 1605. Besides the personal, emotional, upset, both of these deaths also carried financial setbacks. With Francis, the war time treasure that was turned into quick currency ended and Bathory was forced to make ends meet with less profitable crops and wines. ${ }^{102}$ The death of her brother meant she no longer had access to the fortune of her birth family; her brother died without children, so a distant cousin in a cadet branch of the family inherited over Bathory. ${ }^{103}$

Bathory was more successful filling the emotional vacuum in her friend and companion, Anna Dorvula, who began living in Bathory's court around 1601. Almost nothing is known about Dorvula except that she was Croat and that she died of a stroke in 1609. She had a reputation as a witch and, according to the confessions of Ilona Jo, Janos Fiziko, and Dorottya Szentes, she was the one who taught Bathory how to beat and torture young women and girls to death. ${ }^{104}$ Torturing servants, particularly female ones, was a common practice in the Nadasdy-Bathory household before 1605. Francis himself taught his wife a technique to rouse servants that involved rolling pieces of oiled paper

\footnotetext{
101 Thorne, Countess Dracula, 106; Craft, Infamous Lady, 70.

102 Craft, Infamous Lady, 76.

${ }^{103}$ Craft, Infamous Lady, 87.

${ }^{104}$ Craft, Infamous Lady, 62; Penrose, Bloody Countess, 124.
} 
between a servant's toes and lighting the paper on fire. ${ }^{105}$ Sadistic punishments for servants were not unknown, but Francis never let the punishments cause death. It was only after he died that the fatal beatings occurred with any real regularity.

By 1609 Bathory had two pressing problems: low coffers and no victims. The solution to both was a gynaeceum. Although the word was originally the term for the women's sanctuary in an ancient Greek household, by the 1600 s it was also a term for a finishing school. ${ }^{106}$ In exchange for a fee, Bathory taught the daughters of lesser nobility all the manners and etiquette expected at the Viennese court. Although serfs and peasants were unwilling to send their daughters to work for the Countess anymore because of the rumors of torture and murder, lesser noble families did send their daughters to her. Unfortunately they sent the girls to their deaths; within three weeks every single one of Bathory's students was dead. None of the bodies were released to the grieving families. $^{107}$

While the deaths of peasants were ignored, when Matthias II received complaints from noble families about suspicious deaths at Cjesthe of their daughters, he had to act. George Thurzo had just been elected to the position of Palatine and one of his first duties was to investigate the rumors against the Countess. Between March and July of 1610, judges appointed by Thurzo visited the villages around Cjesthe. ${ }^{108}$ All they uncovered was rumors, but they uncovered lots of them, too many for Thurzo to ignore with nobles complaining. More damning was when a letter from Pastor Janos Ponikenusz, the priest of Cjesthe's chapel, arrived, reporting that he had found the bodies of nine girls in the

\footnotetext{
${ }^{105}$ Penrose, Bloody Countess, 42.

${ }^{106}$ Craft, Infamous Lady, 107.

${ }^{107}$ Craft, Infamous Lady, 107-108.

${ }^{108}$ McNally, Dracula was a Woman, 63; Craft, Infamous Lady, 120-121; Thorne, Countess Dracula, 60.
} 
catacombs between Cjesthe and his chapel. ${ }^{109}$ Bathory was now facing accusations from nobles and the church. If she was found guilty of murder, she would be beheaded and the family could loose their noble status by association. Thurzo was trapped between a rock and a hard place; it was his duty to see there was justice, but he also had to ensure that Bathory's rights as a noble were not ignored, and he had been charged with protecting Bathory specifically by her late husband.

Thurzo's solution was unorthodox - he wrote to Bathory's son and sons-in-law and told them about the investigation and what he had found. Paul Nadasdy was still too young to make legal decisions on his own, so his legal guardian, Imre Megyeri, was also included in the letters. The full conversation between the men was lost, but the solution was recovered. The family agreement gave Thurzo permission to confine Bathory and take her accomplices to trial. So long as Thurzo was able to prevent the case against the Countess from going to trial, the family would not get in his way. ${ }^{110}$ Bathory was originally supposed to be sent to a convent after she was arrested, but the plan was changed. ${ }^{111}$ The family agreement was not strictly legal, but exemplified the type of special treatment the aristocracy received from the Early Modern judicial process.

The family agreement in hand, Thurzo decided to give Bathory one last chance. He, Matthias, and several others joined her to celebrate Christmas Eve at Cjesthe. Bathory was well aware that questions were being asked about her, and she had already taken steps to protect herself. She had a written statement from the mother of one of her

\footnotetext{
${ }^{109}$ McNally, Dracula was a Woman, 63; Craft, Infamous Lady, 115; Penrose, Bloody Countess, 64.

${ }^{110}$ Penrose, Bloody Countess, 161; Craft, Infamous Lady, 122; Thorne, Countess Dracula, 160; McNally, Dracula was a Woman, 61.

${ }^{111}$ McNally, Dracula was a Woman, 61.
} 
servants that affirmed that the girl had died of illness. ${ }^{112}$ Bathory had also contacted her cousin, King Gabor Bathory in Poland, for safe passage to his kingdom. ${ }^{113}$ It was also possible that Bathory tried to poison Thurzo and Matthias that night, in another attempt to protect herself, though all that happened was both men were sick. ${ }^{114}$ Over dinner, Thurzo confronted Bathory with the rumors he had uncovered and asked her if there was any truth in them. At first she gave her normal reply that all the deaths were from disease. But when Thurzo pressed, Bathory became angry and left the banquet. ${ }^{115}$

On December $29^{\text {th }}, 1610$, Thurzo returned with a small squad of soldiers, Megyeri, Ponikenusz, and Bathory's sons-in-law to arrest the Countess. Thurzo's report to Matthias recorded they met no resistance as they entered the castle and began to look for her. On the way to the dungeons, the arresting party found one dead girl in the hallway, beaten to death. When they got to the dungeons they found Ilona, Katalin, and Dorottya cleaning up from another session. ${ }^{116}$ The three were arrested, and the victim was found to be alive, if just barely. When the Countess was found, she was immediately arrested. ${ }^{117}$ Initially she was locked in her own dungeons, but was later moved to her rooms upstairs. She was not walled in with only a slit for food and air, but she was under house arrest. ${ }^{118}$ Bathory continued to profess her innocence, and even went so far as to blame the servants for making her do it. ${ }^{119}$ But while three of her accomplices were executed and one imprisoned for life, Bathory was never brought to trial.

\footnotetext{
${ }^{112}$ Craft, Infamous Lady, 123; Thorne, Countess Dracula, 152.

113 Thorne, Countess Dracula, 158; Penrose, Bloody Countess, 155.

${ }^{114}$ Craft, Infamous Lady, 128.

115 Craft, Infamous Lady, 125-126; Penrose, Bloody Countess, 160.

${ }^{116}$ Craft, Infamous Lady, 2; Penrose, Bloody Countess, 166.

${ }_{117}$ Penrose, Bloody Countess, 166; Craft, Infamous Lady, 132; Thorne, Countess Dracula, 167.

118 Thorne, Countess Dracula, 167; Craft, Infamous Lady, 132-3; Penrose, Bloody Countess, 168.

${ }^{119}$ Craft, Infamous Lady, 137.
} 
On August $21^{\text {st }}, 1614$, a guard found her food tray untouched and opened the door. Countess Elizabeth Bathory was lying on her bed, her feet on her pillow, dead at the age of fifty-four. The exact cause of her death is still unknown, though a guard later recalled that the night before her death she had complained of having cold hands. ${ }^{120}$ Very likely the cause of death was heart failure. The Countess was initially buried at the Cjesthe chapel graveyard, but after villagers complained, her body was moved to an undisclosed location. $^{121}$

Did Thurzo and Matthias target her on a flimsy excuse and bend the rules to lock her away in an attempt to get her land and money? Was she targeted because she was a powerful widow? And even if she was guilty, why was she denied a trial - a direct violation of her noble rights? Answering these sorts of questions by looking at historical context is the ultimate goal of this thesis. Bathory was not targeted by any kind of gender or political conspiracy, but rather because her suspicious activity and unsatisfactory answers lead to wide-ranging noble outrage that had to be dealt with by the authorities. While denying her a trial was a violation of her noble rights under the Tripartitum, it was a purposeful action supported by her family that served to protect the Bathory and the Nadasdy name in Royal Hungary. Once removed from the toxic sensationalism of conspiracy and the occult, and transplanted into the contextual norms for Early Modern women (and specifically widows) and children, as well as the contemporary judicial culture, Bathory's case blossoms into a telling lesson about Eastern European Early Modern aristocratic noble women and their position and power. It also demonstrates the

\footnotetext{
${ }^{120}$ Thorne, Countess Dracula, 199; Craft, Infamous Lady, 184-185.

${ }^{121}$ Thorne, Countess Dracula, 200; Craft, Infamous Lady, 185.
} 
surprising flexibility regarding legal procedure, and a deeper understanding of femaleperpetrated crime in Early Modern Europe and our own world. 


\section{CHAPTER II}

\section{BELOVED LITTLE MONSTERS?}

RAISING A NOBLE CHILD

IN EARLY MODERN

\section{EUROPE}

The Enthusiasts, as well as true crime writers, have all linked Bathory's childhood with her future crimes. The argument was that she was raised to be cruel and unfeeling towards others, which was how she was able to kill so brutally and still believe she was innocent. ${ }^{122}$ Her cruelty training began young when she spent time with her older brother, Steven Bathory, who was a lecherous alcoholic tavern brawler. ${ }^{123}$ The training continued with her aunt, Klara Bathory, a bisexual witch and murderess of four husbands. She instructed her young niece on all types of torture, sexual exploits, and encouraged her to practice the occult. ${ }^{124}$ Folklore stated that she watched a gypsy being punished for selling children to the Turkish by being sewn into a horse's belly up to his neck and left that way to die. ${ }^{125}$ The rest of her family was no better, and Bathory grew up surrounded by men

\footnotetext{
${ }^{122}$ McNally, Dracula was a Woman, 21; Thorne, Countess Dracula, 20; Penrose, Bloody Countess, 14; Craft, Infamous Lady, 13-14.

${ }^{123}$ Craft, Infamous Lady, 11-12.

${ }^{124}$ Penrose, Bloody Countess, 18; McNally, Dracula was a Woman, 33.

${ }^{125}$ McNally, Dracula was a Woman, 21.
} 
and women who worshipped Satan, chased ghosts, and heard voices. ${ }^{126}$ For profilers, establishing that Bathory was raised in a cruel and unstable environment was vital to explaining why she eventually turned into the most infamous female serial killer in the world. Such an environment has been established as the start of a killing career. Unfortunately for the profilers, these stories of being raised in a cruel and terrible environment were false. Bathory was not trained to be cruel, and she did not raise her children to be cruel. Part of the legend of the Countess was that she was aware of her inferiority in her world from an early age because she was a girl. The assumption of cruelty and inferiority hinged on her upbringing and the lessons learned there carrying into adulthood. So to hope to understand the place of noblewomen in Eastern European, the beginning lessons must be examined for their cruelty. Since Bathory had a typical Royal Hungarian childhood, as shown in the previous chapter, if she was raised to be cruel, it should follow that other children were as well. Unfortunately for those who support the idea that she was raised cruel, there is no evidence in Hungary of such training.

Ideas about childhood have changed since the Early Modern Era, but did noble families actually raise their children to be cruel? The evidence from Europe in general, and Hungary in particular, discredit this idea. No evidence has indicated that Bathory and her three siblings were trained to be cruel, nor did Bathory raise her own children in a cold and distant environment. The idea that she was raised as such came from a combination of profilers needing to explain her later crimes (as indicated above); folklore, which made her more of a monster; and a growing need to discredit the nobility.

\footnotetext{
${ }^{126}$ Penrose, Bloody Countess, 14; McNally, Dracula was a Woman, 19; Craft, Infamous Lady, 11; Thorne, Countess Dracula, 83.
} 
Childhood was a special time of innocence in Early Modern Europe, regardless of social position. If Bathory's parents had raised her to be cruel, they were highly abnormal.

Bathory's childhood was not discussed at the trial of her accomplices, which has been the main source of information for her life from the start. This suggests, quite strongly, that Bathory's own contemporaries did not consider her childhood to be of particular importance to the case. In other words, it was so typical there was no reason to discuss it. Therefore, stories of her upbringing were likely an amalgamation of all the worst stories of the nobility. Over time the natural exaggeration inherent in story telling, combined with efforts to dehumanize the nobility gave these stories a life and validity of their own, regardless of historical evidence to the contrary. To counter these stories, new importance is placed on understanding childhood in Early Modern Europe and how childhood affected Bathory's experiences, both as a child and as a mother, must be evaluated and understood. The Enthusiasts have not done this before for two main reasons: very few records of her early life have survived, and only a few sources discuss childhood in Early Modern Hungary. Recent scholarship on the make-up and function of the Early Modern family in various countries throughout Europe, combined with archeological evidence, has greatly expanded the general historical understanding of childhood across Europe. With these sources it is possible to re-construct a general Early Modern European childhood, at least for noble or urban children. ${ }^{127}$

Regardless of social position, childhood was special for Early Modern European parents. While a higher level of violence was accepted from noble children, they were not

\footnotetext{
${ }^{127}$ Due to a lack of records, peasant families remain broad caricatures.
} 
raised to be cruel. ${ }^{128}$ Childhood was not a time to instill gender norms for parents. Until about the age of ten, boys and girls were raised almost the same, and a child's biological sex determined less about his or her life than the social and economic status of the family. For most of the populace, the family was a unit of production first and a source of emotional support second, if at all. ${ }^{129}$ Nobles had children to ensure property and continuity of the noble name, and to strengthen the web of political alliances through marriage. This was not a significant change from the way noble families had worked in the Middle Ages, but there was a perceptible shift towards the idea of a nurturing relationship between parents and children.

The modern popular perception of family and child rearing at this time has been decidedly dark and inaccurate. Started by Philippe Ariès, the belief was that children were born and usually ignored until they survived the most dangerous ages of childhood; then they were put to work for the family. ${ }^{130}$ There was no real childhood, except for in the physical sense, regardless of social or economic status. Parents kept themselves at

\footnotetext{
${ }^{128}$ Adam Batthyany's sons were reported to fight often while in school. At least one of these fights involved a knife, when one brother stabbed the other in the hand. This was still considered normal sibling rivalry. Istvan Fazekos, "Count Adam Batthyany I and his Children" in Beloved Children: History of Aristocratic Childhood in Hungary in the Early Modern Age ed. Katalin Peter tran. Rachel and Janos Hideg (Budapest: Central European University Press, 2001), 170.

${ }^{129}$ Lisa DiCaprio and Merry E. Wiesner, ed. Lives and Voices: Sources in European Women's History (Boston: Houghton Mifflin Company, 2000), 177; Marzio Barbogli and David I. Kertzer, "Introduction" in The History of the European Family Volume One: Family Life in Early Modern Times, 1500-1789 ed. David I. Kertzer and Marzia Barbogli (New Haven: Yale University Press, 2001), xxvii.; Katalin Peter, "Historical Background" in Beloved Children: History of Aristocratic Childhood in Hungary in the Early Modern Age ed. Katalin Peter tran. Rachel and Janos Hideg (Budapest: Central European University Press, 2001), 51-52.

${ }^{130}$ Barbara A. Hanawalt, Growing Up in Medieval London: The Experience of Childhood in History (New York: 1993), 7; Nicholas Orme, Medieval Children (New Haven: Yale University Press, 2001), 4.
} 
arms length from their children because it was so likely they would die that it was considered ill-advised to become too close. ${ }^{131}$

For noble children, there was only a vague understanding of parents since children were fobbed off on wet nurses, then dry nurses, then an assortment of nannies, tutors, and guardians until it was time for them to get married. ${ }^{132}$ For girls in Eastern Europe, this meant leaving their family home to take up residence with the groom's family. For boys, marriage meant a new suite of rooms and a larger household to accommodate their new duties. The new couple had children and the cycle repeated. The idea that children were just little adults was pervasive, and dictated the treatment of children. Because children needed strict discipline, beatings, administered by servants when ordered by the parents, were considered acceptable punishments. ${ }^{133}$ The idea of fond memories of childhood was non-existent.

Work by historians such as David Herlihy, David Nicholas, Barbara A. Hanawalt, Nicholas Orme, and a host of others since 1973 based on archeological evidence and documents from noble families has shifted that perception dramatically. While certain elements remain true, more have started to crumble, specifically the idea that Early Modern Europeans did not have a childhood, which included time to play and affection from parents. Families recognized that children were not just small adults, and that children did require special treatment and care. ${ }^{134}$ Archeological digs have uncovered young children buried between parents, as well as tiny pots and simple figurines that

\footnotetext{
${ }^{131}$ Linda A. Pollock, "Parent-Child Relations" in The History of the European Family Volume One: Family Life in Early Modern Times, 1500-1789, ed. David I. Kertzer and Marzia Barbogli (New Haven: Yale University Press, 2001), 196.

${ }^{132}$ Pollock, "Parent-Child Relations," 191.

${ }^{133}$ Herlihy, Women, Family, and Society, 158.

${ }^{134}$ Herlihy, Women, Family and Society, 151.
} 
were likely used as toys, which suggested that even for peasants, for whom it was largely a production unit, the family was also a place to find shelter, love, and support. ${ }^{135}$

Children were encouraged to play, particularly outdoors. Even teaching a child to write was treated as a type of game in which the child mimicked the parent writing letters by scribbling and then incorporating actual letters. ${ }^{136}$ To encourage playtime and socialization, peasant children, often those of servants or nurses, were brought in as playmates to the castle. ${ }^{137}$ Children played ball, raced, went horse back riding, and play fought with each other when they could play outside. In the winter they ice skated using rib bones tied to shoes. When weather did not allow for outside play, card games, dice, and other toys were played with. ${ }^{138}$ One particularly elaborate toy was a brass clock work jousting set, which allowed a child to reenact a joust in miniature. ${ }^{139}$

While the specifics of Bathory's childhood are not known, the Enthusiasts, particularly McNally and Craft, have all agreed that it was filled with horse back riding, foot races, and other games. ${ }^{140}$ McNally argued that she was, to use a modern phrase, a tomboy who enjoyed playing with boys. However, she also loved to dress up in fancy clothing and wear heavy jewelry. ${ }^{141}$ The truth remains unknown, but there was no evidence that she had an abnormal childhood in regards to the first ten years of her life.

Expensive toys like the brass jousting set were the exclusive right of noble children, who were always in danger of being spoiled. Parents tried to counter this by

\footnotetext{
${ }^{135}$ Sander Petenyi, Games and Toys in Medieval and Early Modern Hungary tran. Alice M. Choyke and Laszlo Bartosivicz (Kapite: Krems, 1994), 83.

${ }^{136}$ Peter, "First Ten Years of Life," 79.

${ }^{137}$ Peter, "First Ten Years of Life," 79.

138 Peter, "First Ten Years of Life," 73.

139 Petenyi, Games and Toys, 97-98.

${ }^{140}$ Craft, Infamous Lady, 38; McNally, Dracula Was a Woman, 29; Penrose, Bloody Countess, 53; Thorne, Countess Dracula, 105.

${ }^{141}$ McNally, Dracula was a Woman, 33
} 
instilling discipline and respect. In order to receive presents from his father, Bathory's future husband, Francis Nadasdy, had to write his own letters to him and be on his best behavior. If his mother, Ursula, reported that Francis had not behaved as expected, there would be no gifts. ${ }^{142}$ Children received gifts from their fathers or other male relations, and from those seeking to win favor with their parents. Gifts included clothes, toys, or even exotic fruits, and pleasing the child often made the parents more open to whatever was being proposed by the gifting party. ${ }^{143}$ If Hungarian noble parents truly kept their children at arm's length, such efforts would have been a waste of money and time.

The key evidence for the emotional and financial investment that children represented for parents was in the selection of a wet nurse. Although the use of a wet nurse has become anathema to the modern parent, for the noble Early Modern European mother it was essential. Not only did it allow the mother to return to the duties of running the household much sooner, but it also maintained her beauty and her sex drive. ${ }^{144}$ It was widely believed that breast feeding drained a woman's beauty, which was indicative of good health, but was necessary for strong children. Therefore, handing children over to a wet nurse was a pragmatic decision rather than a sign of parental neglect.

And choosing a wet nurse was no easy task either. The woman chosen had to be in good health and have a number of healthy children herself. ${ }^{145}$ For at least the next year, this woman's life revolved around the raising and care of the new lord or lady. ${ }^{146} \mathrm{Her}$ children were playmates and possibly classmates for her charge, and she could expect to

\footnotetext{
${ }^{142}$ Peter, "First Ten Years of Life," 72.

${ }^{143}$ Peter, "First Ten Years of Life," 72.

${ }^{144}$ Pier Poola Wiazzo, "Mortality, Fertility and Family," in The History of the European Family Volume One: Family Life in Early Modern Times, 1500-1789 ed. David I. Kertzer and Marzia Barbogli (New Haven: Yale University Press, 2001), 166.

${ }^{145}$ Peter, "First Ten Years of Life," 75; Orme, Medieval Children, 58.

${ }^{146}$ Peter, "First Ten Years of Life," 76.
} 
be very close to the family in general. ${ }^{147}$ If she did particularly well, she would be wet nurse to multiple children of the same family. The wet nurse had to be someone incredibly trustworthy, because she not only cared for the future of the family in its earliest years, but she also had access to many family secrets. Certainly in the case of Bathory this was true since one of her accomplices, Ilona Jo, was her children's wet nurse. $^{148}$

But the wet nurse was just the first in an army of nurses, servants, and handlers that a noble child was exposed to. Noble children received their own household to care for them, including their own cook. Adam Batthyany, whose own father was in regular correspondence with Bathory, kept meticulous records of his children's household. ${ }^{149}$ The Batthyany children had wet and dry nurses and the nurses had their own cook, kitchen, and rations of food which included meat. ${ }^{150}$ When the children were old enough, tutors were added to the mix, as well as valets, footmen, and at least one steward to help keep that household in line. In 1649, Batthyany sent his two sons to school with a thirteen person retinue. $^{151}$

Despite having a household that was specifically designed to serve and care for them, noble children were very aware of the presence and authority of their parents. Child rearing was considered very much a two person job in Hungary. The mother was often the primary caregiver, but the father had specific and important roles in his children's life

\footnotetext{
${ }^{147}$ Peter, "First Ten Years of Life," 76; Orme, Medieval Children, 58-59.

${ }^{148}$ Penrose, Blood Countess, 58.

149 The Batthyany family was nearly as powerful as the Bathory family, and the Countess frequently turned to Francis Batthyany for military support and political advice after her husband died. Because of this, it is reasonable to assume that the Bathory children had the same advantages described for the Batthyany children.

${ }^{150}$ Fazekos, "Count Adam Batthyany I and his Children," 167.

${ }^{151}$ Fazekos, “Count Adam Batthyany I,” 169.
} 
as well. It was the role of the father to escort his children to and from visits to friends and relations. ${ }^{152}$ When a child fell ill or became homesick, it was expected that the father drop everything he was doing to bring the child home. Fathers were expected to put family first and take over care of the children if anything happened to the mother, even if she was merely traveling. And most fathers seem to have enjoyed showing off their children, both male and female, taking them on trips and to sessions of the Diet or to court. ${ }^{153}$ This ran counter to the wider opinion of Europe that having men care for a child was illadvised. Stories from Ghent and Flanders told of fathers who were miserable with their children in tow, and of men giving children knives and other sharp implements to play with because males were poor caretakers of children. ${ }^{154}$

But the most important thing for parents was the health of their children, which was understood to be very much in the hands of mortal, not divine, forces. Good nursing and care were essential to a child's survival and therefore was not taken lightly or treated in the flippant manner so often imagined by the popular image. ${ }^{155}$ Wet nurses' diets were strictly monitored so they did not consume anything that might harm the baby. If an infant needed medicine it was often the wet nurse who consumed it and the baby got the medication through breast milk. ${ }^{156}$ In Hungary, it was only in official announcements regarding the death of children that God's will was mentioned. ${ }^{157}$ In private correspondence, however, parents were very aware that human hands were more directly involved; there are no surviving accounts of parents expressing anger at God for the loss

\footnotetext{
${ }^{152}$ Peter, "First Ten Years of Life," 69.

${ }^{153}$ Peter, "First Ten Years of Life," 60-62.

${ }^{154}$ David Nicholas, The Domestic Life of a Medieval City: Women, Children, and the Family in Fourteenth Century Ghent (Lincoln: University of Nebraska Press, 1985), 110.

${ }^{155}$ Peter, "First Ten Years of Life," 85; Orme, Medieval Children, 58.

${ }^{156}$ Orme, Medieval Children, 58.

${ }^{157}$ Peter, "First Ten Years of Life," 87.
} 
of a child. ${ }^{158}$ In the eyes of parents of Early Modern Hungary, a child's survival was less in the hands of an ethereal presence, and more the result of human care, or lack there of. How far this carried over into wider Europe varies on location, but children's deaths were often blamed on bad milk from a wet nurse. ${ }^{159}$

All children entered the world the same way -- to a room filled with female relatives. Since an uncomplicated pregnancy and birth was expected in Hungarian noble households, a midwife was not present, but when one was deemed necessary, it was the job of the father to fetch one. ${ }^{160}$ Written announcements of the birth of a child were usually solemn but always made sure to specify the gender of the child. ${ }^{161}$ Even in families where there was an heir and multiple spares, boys were always welcome. Despite those hopes for sons, there was no evidence that daughters were actively discriminated against. ${ }^{162}$

In both noble and peasant homes, when it came to a child's sex, boys were always desired over girls, but this desire was purely economic. Sons were able to inherit property without complicated and expensive legal haggling; they were able to enter the production system more directly; and they did not require the family to pay for weddings. Therefore, there was usually a sense of disappointment when a girl was born, even more so if the family had multiple daughters already. But the disappointment did not last long. Daughters were, in general, more doted on than their brothers, and in cases where a

\footnotetext{
158 Peter, "First Ten Years of Life," 87.

159 Orme, Medieval Children, 59.

${ }^{160}$ Peter, "First Ten Years of Life," 54.

161 Peter, "First Ten Years of Life," 58.

162 Peter, "First Ten Years of Life," 60.
} 
daughter died in childhood, were more frequently and elegantly mourned by their parents. ${ }^{163}$ Sons, therefore, were more profitable, but daughters were more loved.

Education was important for all noble children. Children learned to read and write around the age of three or four, usually in at least their vernacular and Latin. Although the overall literacy rate for Early Modern Europe was low, for the nobility by the sixteenth century it was considered essential that every child be able to read, write, and perform basic arithmetic. By the middle of the sixteenth century, nobles who were illiterate tried to hide the fact out of embarrassment. ${ }^{164}$ For boys the reasons were obvious; they needed these skills in their future political positions as leaders of the realm. But these lessons were considered just as important for girls to learn as well, and by 1600 , the literacy rate of noble women was nearly one hundred percent. ${ }^{165}$ An illiterate noblewoman made a very poor wife since she was unable to properly run a household, including calculating food rations, ordering supplies, and writing letters. ${ }^{166}$ She was also considered a very poor mother, since she could not read the Bible to teach her children good Christian morals. ${ }^{167}$ Therefore, both sons and daughters were given at least a primary education directly by their parents when they were young, then by tutors when they became old enough. As an example of the importance of literacy, it was considered shocking when Thomas Nadasdy, Francis's father and Palatine of Hungary, married an

\footnotetext{
${ }^{163}$ Fairchilds, Women in Early Modern Europe, 38.

${ }^{164}$ Istvan Gyorgy Toth, Literacy and Written Culture in Early Modern Central Europe (Budapest: Central European University Press, 2000), 97.

165 Johnathon DeWold, The European Nobility, 1400-1800 (Cambridge: Cambridge University Press, 1996), 152.

${ }^{166}$ Fairchilds, Women in Early Modern Europe, 19.

167 Jeffery R. Watt, "The Impact of the Reformation and Counter-Reformation," in The History of the European Family Volume One: Family Life in Early Modern Times, 1500-1789 ed. David I. Kertzer and Marzia Barbogli (New Haven: Yale University Press, 2001), 143; Fairchilds, Women in Early Modern Europe, 191.
} 
illiterate, but incredibly wealthy, noblewoman. It has often been held up as an example of romantic love among the nobility, because Thomas so was charmed by Ursula that he married her despite this, and made it a priority to see that she was taught to read and write so they could communicate while he was away from home on official duties. ${ }^{168}$ Surviving letters indicated she never learned to write well or particularly elegantly, but this experience did make the couple strong believers in education when it came to their son. ${ }^{169}$

Noble children's lives branched off into more gender specific education and refinement only after the age of ten. There were some instances of gender instruction early on in the form of toys. The jousting set mentioned earlier reinforced the role for males to participate in the military. One item that did not appear often was dolls. Very few have been recovered, and there was little mention of them in letters. ${ }^{170}$ Either dolls were made of materials that did not survive to the modern day, or the concept of a doll as a toy was limited.

Around the age of ten the process of preparing a boy or girl for their future position as a noble began in earnest. For boys that included preparation for higher education and military service. But for girls, education entailed learning to run and maintain the household she would eventually oversee for her husband. It also included rather strict religious training and a lack of emphasis on the academic. It was widely believed that once a girl entered puberty, her mind became so consumed with sexual desire that she was unable to focus on any subject matter, and therefore needed to be

\footnotetext{
${ }^{168}$ Craft, Infamous Lady, 23.

${ }^{169}$ Craft, Infamous Lady, 27.

${ }^{170}$ Peter, "First Ten Years of Life," 73; Petenyi, Games and Toys, 96.
} 
taught to avoid the sin she was so inclined toward. ${ }^{171}$ How seriously this was taken varied from parent to parent, but daughters received more religious education than their brothers in general. There was of course a secondary reason to have girls learn more about religion than boys; it was the job of the mother to teach her children proper Christian morals. Therefore, regardless if a particular family truly believed that a girl's brain was too consumed to handle more complex academic pursuits, it was considered essential that she receive strict biblical training.

Arguments regarding women's education continue to be debated among historians like Merry Weisner, Julie Hardwick, Barbara Whitehead and a host of others, with some arguing that women and girls of Early Modern Europe were denied a true education, and others arguing that women were educated, but not in the modern sense. Both arguments have merit. Women were not allowed to attend institutes of higher education. And for a woman to have an occupation of her choosing was only truly possible in a specific set of circumstances, such as if she was very wealthy and was not under any pressure to marry or have children. Even when a career was deemed necessary, there were limited options, but poetry or painting was often acceptable. ${ }^{172}$ Though not entirely unheard of, a woman in Early Modern Europe who achieved status and support as an academic was rare. It was therefore unsurprising when early works on women compared the advancement of men's academic careers and declared that women had been denied the educational benefits of the Renaissance. ${ }^{173}$

\footnotetext{
${ }^{171}$ Fairchilds, Women in Early Modern Europe, 46.

${ }^{172}$ Bogucka, Women in Early Modern Polish Society, 149.

${ }^{173}$ Julie Hardwick, "Did Gender Have a Renaissance? Exclusions and Tradition in Early Modern Western Europe" in A Companion to Gender History ed. Teresa A. Meade and Merry E. Wiesner-Hanks 
But assertions by early historians like Kelly-Gould that women and girls were left entirely uneducated ignore the historical evidence. Numerous letters and diaries, as well an ecclesiastical initiative to encourage reading the Bible from both Catholicism and the many branches of Protestantism, testify to the literacy of noble women. And while running a household may seem a rather mind-numbing prospect to the modern woman, it was not as simple as folding sheets and ordering around servants. Running a household meant paying bills, keeping lines of credit with merchants, maintaining rations of food, cloth, and medicinal supplies for a household of several dozen, organizing the labor of serfs so that fields were planted or harvested properly, ordering and paying for repairs to the home and defensive walls, and balancing accounts of sales of livestock, wine, or other produce. ${ }^{174}$ All this had to be done for not just one home, but for several. In the case of Bathory, it had to be done for twenty estates. ${ }^{175}$ Such demands could not have been placed upon anyone, regardless of gender, who did not have some kind of education. If the definition of education was expanded to include vocational training, and not just that of academia, women and girls become significantly more educated, with noble women even more so. ${ }^{176}$ Bathory's supposed high level of education has also been used to explain some of her eccentric behavior, including the suggestion that this education made her keenly aware that while she might have been the brightest crayon in the box, so to

(Molden: Blackwell Publishing, 2004), 343; Dolen, "Gender and Sexuality," 7; Madean, Renaissance Notion of Women, 4.

${ }^{174}$ Michalove, "Equal Opportunity?" 51; Bogucka, Women in Early Modern Polish Society, 33-35.

${ }^{175}$ Craft, Infamous Lady, 37

${ }^{176}$ Barbara J. Whitehead, "Introduction" in Women's Education in Early Modern Europe: A History 1500-1800 ed. Barbara J. Whitehead (New York: Garland Publishing, Inc., 1999), xi. 
speak, she was still a secondary color. This awareness caused her to lash out in the only way she possibly could, by beating and abusing those less fortunate than her. ${ }^{177}$

Of course the issue with this was that Bathory did not actually receive a high level of education. While she may have benefited academically from the Renaissance Humanist household in which she was raised by gaining access to more subjects, Bathory's education looked very similar to that of other noble girls. In one way she received less of an education: evidence that Bathory ever attended the Vienna court for educational purposes has not survived, and she probably never did. She was able to achieve a good marriage without regular court attendance, so her education immediately shifted to learning how to maintain a household in the Nadasdy family seat of Sarvar. Ideally she would have learned all this through an apprenticeship-shadow relationship with her mother in law, but by the time she arrived, Ursula was dead. ${ }^{178}$ Therefore assertions by Penrose and McNally that her atrocities began as a way to get vengeance by proxy on her tyrannical mother-in-law were also false. The lack of tutelage under birth mother or mother-in-law meant that Bathory learned by a combination of trial and error, or by studying closely with the stewards of the estates. Some of her early letters to merchants for orders and payments were reviewed by Francis, as evidenced by his signature, suggesting that her practical education was a team effort and contained a lot of trial and error.

Our thanks, after which we wish to inform you that we desire to see this letter delivered out in full without any delay. Give to Peter Szalai two

\footnotetext{
${ }^{177}$ Stephan J. Giannangelo, The Psychopathology of Serial Murder: A Theory of Violence (Westport: Praeger Publishers, 1996), 40; Trevor Dean, Crime in Medieval Europe 1200-1550 (Harlow: Pearson Education, 2001) 32.

${ }^{178}$ Craft, Infamous Lady, 16; Thorne Countess Dracula, 90.
} 
stone of wheat and nothing more. God keep you. Done at Keresztur, January 12, 1589

Lord Francis Nadasdy

Lady Elizabeth Bathory

Our thanks and appreciation, after which we wish to inform Your Grace that we desire to see this letter delivered out in full without delay. Your Grace, give one stone of wheat, this all to Gergel. This is not optional. God keep you. Done at Sarvar, Saint Vid Evening, 1589

Lord Frances Nadasdy

Lady Elizabeth Bathory

Our thanks and appreciation, after which we wish to inform Your Grace that we desire to see this letter delivered out to all without any delay. Give to Miklos Buki two stone of wheat and nothing more. God keep you. Done at Keresztur, June 22, 1589

Lord Francis Nadasdy

Lady Elizabeth Bathory ${ }^{179}$

The duel signatures showed that both husband and wife were involved in running the household, even fifteen years after the marriage. The letters also showed how involved a noble wife's duties were for the home since Bathory orders specific measures of wheat to particular merchants and leaves no room for argument or discussion in the tone of the letters. These were not the sorts of tasks wisely left to someone who had not received at least a basic education, and the authoritative tone can only be achieved after years of practice

How to dictate cereal grain distribution were not the only lessons Bathory and her children learned. Other elements of a noble child's education important for court life included dancing, dress, etiquette, some type of artistic skill, and the art of small talk. ${ }^{180}$ How children received this courtly education varied according to how wealthy or well

\footnotetext{
${ }^{179}$ Kimberly L. Craft, The Private Letters of Countess Erzsebet Bathory (Lexington: Created Space, 2011), 22.

${ }^{180}$ Fazekos, "Count Adam Batthyany I," 177; DeWold, The European Nobility, 47; Raffaella Sorti, "The Material Conditions of Family Life," tran. Caroline Beamish in History of the European Family ed. Kertzer and Barbogli, 14.
} 
connected the parents or family was. Some children received their entire education through private tutors; others learned by direct experience in a method that strongly resembled an apprenticeship; and others were sent to court.

Time at court usually started for Hungarians at the legal age of fourteen and ended around the age of twenty. Court, usually Vienna for Hungarian nobles, was considered the best method of education for noble children. ${ }^{181}$ For sons it provided an opportunity to network and hone the fighting skills they were expected to use in defense of the nation. Those who did well at court were assured of continued recognition and power for the rest of their lives. Those who did not do so well had the chance to make friends with those who did. It was at court that Bathory's husband, Francis, a mediocre academic, was truly able to shine in displays of physical fortitude. ${ }^{182}$ By the end of his time at court, just before his marriage to Bathory, he held the military rank of captain, and by the end of his life he had been given the court rank of High Stable Master, all in recognition of his prowess in combat. ${ }^{183}$ Less achieved militarily was his friend, future Palatine George Thurzo, who none the less was able to form strong political connections through his time at court and his friendship with Nadasdy. ${ }^{184}$

For daughters, court was a chance to hone specific skills like witty conversation and staff management that allowed them to make a strong marriage, which was the best way for a girl to serve her family. At court she studied through observation and experience the latest in fashion and etiquette, and then used these skills, along with witty banter and good breeding to snare one of the promising young men that were also trying

\footnotetext{
${ }^{181}$ Peter, "The Later Ottoman Period," 109; Bogucka, Women in Early Modern Polish Society, 130-131.

${ }^{182}$ McNally, Dracula Was a Woman, 28; Thorne, Countess Dracula, 88; Craft, Infamous Lady, 27.

${ }^{183}$ Craft, Infamous Lady, 39.

${ }^{184}$ Thorne, Countess Dracula, 125; Palffy, Hungary, 81.
} 
to make a name for themselves. ${ }^{185}$ Failing to achieve a strong marriage was a

disappointment, but being at court opened the doors for the noble daughter to become a companion for a more powerful noblewoman. Being a servant to a noble in Hungary, a familis, was not a mark of shame and was considered a perfectly legitimate vocation for younger sons or daughters who were unable to find a good marriage. ${ }^{186}$

But Bathory achieved a good marriage, and although it took time, she became a mother and presumably she raised her children as she was raised. As support that she was raised in a cruel environment, her letters to her husband were used by early writers as well as Penrose and McNally to argue she was a distant and cold mother. The letters were written in a straight forward manner and pertained mostly to the children's health, not their accomplishments, feelings, or even educational progress. Early authors believed this indicated she cared very little for her children. ${ }^{187}$ Bathory wrote to her husband,

At your service, I write to you as my beloved husband,

Regarding the children, I can report that Anna and Orsika are healthy. Regarding Kata, however, there is a problem in her mouth: namely, rot has spread there, such that even the jawbone is infected. The Barber poked about the middle of the tooth with an iron - he says it was a stroke of luck that not a single tooth fell out. I do not know how the Lord will bring the matter to an end but right now, it is, in any case, very bad for her. About myself, I can write that things are now going much better than in the past few days....

Written at Sarvar, On Friday after the Ascension of the Lord, 1596 Your Servant, Elizabeth Bathory

At your service, I write to you, my beloved Lord, Regarding the children, I can report that Anna, thank God, is healthy, Kata has eye pain, and Orsika the mouth rot. I am healthy, thank God; only the eyes hurt me. God keep you.

\footnotetext{
${ }^{185}$ Madean, Renaissance Notion of Women, 64.

${ }^{186}$ DeWold, European Nobility, 41.

187 Thorne, Countess Dracula, 118.
} 
Written at Sarvar, on the eighth day of the month of St. James, 1596

Your Servant,

Elizabeth Bathory ${ }^{188}$

Bathory's letters were preoccupied with the health of her children, and she went into great detail regarding it. However, comparing her letters with the letters of not only Adam Batthyany, but also Palatine Thurzo, the health of the children as a main focus was the norm for noble Hungarian parents. ${ }^{189}$ Health was associated with good care, so for Francis to read that his children were in mostly good health, told him that they were being well cared for. The matter of fact tone of her letters was a combination of her classical training and the knowledge that when her husband was at the front he would not have a lot of time to read overly flowery letters. Despite this, Bathory's letters also demonstrate significant parental concern and sympathy to the plights and problems of her children. Phrases like "a stroke of luck" and the multiple thanks to God are not used by distant parents. Bathory's letters reveal a mother who, while efficient, was none the less a loving one, who was heavily invested in her children's lives and attempted to keep her husband equally involved.

If either of her daughters attended court, the records have not survived. ${ }^{190}$ Since they came of age to attend court near the start of the Long Turkish War in 1591, it may have been deemed too risky to have them travel. Both girls, thanks to their mother's dedication to ensure them a good future, had good marriages arranged for them without the need to attend court. Being able to claim relation to the Black Bey of Hungary, the heroic title given to Francis, assured her daughters several promising offers, especially if

\footnotetext{
${ }^{188}$ Craft, Infamous Lady, 50-51.

${ }^{189}$ Peter, "The First Ten Years of Life", 73.

${ }^{190}$ Orsika died of the tooth rot when she was about six.
} 
they were as beautiful as their mother was rumored to be. The lucky grooms must have been considered very good matches since Bathory left substantial holdings to both her sons-in-law before her arrest to make sure they were protected. ${ }^{191}$

More unusual, considering his father's strong reputation was that her son Paul did not attend court for training; instead he remained at the family seat under the legal guardianship of his tutor, Imre Megyeri. The reason for keeping Paul from court was not clear but there were specific factors which might explain it. Because he was the only male heir, it may have been deemed too risky to send him. It may also have been politically motivated; rather than risk sending her son to a court where she was already under suspicion, Bathory may have decided to keep him at home. More likely, however, was that Paul chose not to attend court. Upon his father's death in 1604, Paul became Count Nadasdy, accepting all the rights and responsibilities therein. However, he was eleven, not yet the legal age of fourteen. Hungarian law did not allow his mother to be his guardian as a widow, and so his care was handed over to his tutor who would make any further decisions for him. ${ }^{192}$ His mother still administered the estates and lands of the Nadasdy family, but had no say in her son's education after that point since by law she was no longer considered his legal guardian. By the time she died in 1614, Paul was legal age and likely consumed entirely by the running and maintaining of the Nadasdy lands, as well as maintaining the social standing of the family in the wake of the accusations against his mother.

\footnotetext{
191 Thorne, Countess Dracula, 153.

192 Erik Fugedi, The Elefanthy: The Hungarian Noblemen and His Kindred trans. Csoba Farkas (Budapest: Central European University Press, 1998), 26.
} 
Childhood played a very important part in the understanding and explanation of Bathory. Her childhood, which supposedly emphasized cruelty and establishing superiority on the backs of ethnic inferiors, was used by biographers to explain how and why she committed the crimes she became infamous for. Historical context, specifically the understanding and construction of childhood, made a cruel childhood unlikely. Hungarian noble parents did not keep their children at arms length, and the idea of childhood being a special time of innocence and play made it unsuited to witnessing such drastic punishments as the infamous gypsy and horse episode that has been repeated $\mathrm{ad}$ nauseum.

Although the idea that Bathory suffered a cruel and cold childhood, which she then passed on to her own children, certainly made a good story, the historical context does not support it. Children in Early Modern Hungary and across Europe were recognized as precious beyond the continuation of the family, and parents understood that good care meant the survival of their children. Although the high death rates of children were a reality across Europe, in Hungary that did not stop parents, and friends of parents, from seeking to make their children happy and content. ${ }^{193}$ Childhood was understood, socially, politically, and religiously, to be a special time of life that should not be tainted by the evils of the world. Not only that, but raising children was the full time occupation of an entirely separate household as well as both parents. This kind of financial and emotional investment did not reflect an arm's length style of parenting.

The education of children was immensely important to families as well, beginning early in life and until the age of ten including the same subjects regardless of sex.

\footnotetext{
${ }^{193}$ Some of the numbers from London indicated that the infant mortality rate was about $42.5 \%$. Orme, Medieval Children, 113.
} 
Literacy and other elements of a primary education were considered the norm for noble children and were part of establishing a secure future. The decision to go to court may have been a personal one or a political one, but it was not the only option available to children. Most education was vocationally geared, but no less important. Including historical context from the very beginning of Bathory's life unravels many of the foundations of her legend. Although few records of her childhood survived, by widening the scope of study to include other children, a clearer picture of her world and her place in it emerged. Such a portrait undermines the notion that Bathory experienced a cruel childhood that taught her to be sadistic, and that disregarded her level of education, eventually driving her to commit atrocities. Her actions as a mother were not cold and distant, but rather practical and focused on the health of her children, the mark of a loving mother. If the foundation of her crimes were in her childhood, hers would have been so unusual that it would have merited some kind of notation. All evidence, however, suggested that it was in fact very typical. Her childhood was supportive and nurturing by the standards of Early Modern Europe and did not include any instruction on cruelty or inferiority. Nor would her upbringing have been gendered, at least not until her engagement and marriage. 


\section{CHAPTER III \\ LADY AND MISTRESS OF ALL SHE SURVEYS: \\ WOMANHOOD AND NOBILITY IN \\ EARLY MODERN HUNGARY}

Until about the age of ten, Early Modern Hungarian boys and girls were raised nearly identically as far as activities, toys, and social graces. However, at physical puberty, the process of gendering began; sons were taught all the virtues of masculinity, daughters were instructed on femininity. But daughters of aristocrats also had to embody elements of the masculine, as Bathory did in her authoritative missives to merchants. How did the Early Modern Era react or accept women who had such traits? Were such women viewed as a threat? The Enthusiasts, particularly Craft and Thorne, were adamant that Bathory was targeted by Thurzo and Matthias, and therefore not given proper treatment under the law, because she was a powerful widow who represented a significant threat with no man to control her. For this to be true, women in Early Modern Europe had to be considered a threat unless they were married. Considering the loving environment noble daughters were raised in, to suddenly regard those same daughters as a threat when they grew up seems implausible. All evidence regarding the view of noble women in Early Modern Europe, specifically Eastern Europe, and what is known of 
Bathory's life as a wife and widow negate a conspiracy against her based on gender.

During the Early Modern Era, gender was not actually a binary concept. Gender was more often determined on a sliding scale. It may have been personally embarrassing for a man to be bested in anything by a woman, but the wider view was that a woman could do something as well as or better than a man without negating her femininity. ${ }^{194}$ So while at first the "threat theory" seemed plausible, the place of a powerful widow in Early Modern Hungary was not threatening; the suggestion was imported from Western thinking by the Enthusiasts. Women were marginalized, but Bathory as a wealthy and powerful widow was not a threat to the king or Thurzo. Widowhood alone was not enough to deny her the full rights she was entitled to under the law. Women were not viewed as equals in Early Modern Europe, but when dealing with noble women, they were nobles first and women second.

To fully comprehend this, the theory of gender for Early Modern Europe must be discussed and understood. The Renaissance revived the Aristotelian one gender argument. According to this theory there was only one actual gender, male. Women were simply failed men, but who carried the potential to bear men. ${ }^{195}$ By 1600 this idea had been blended with Galen medical knowledge to create a variation of the one gender theory. ${ }^{196}$ There were two sexes, which were equal regarding their involvement in reproduction. Being biologically female did not immediately equate to inferiority, being

\footnotetext{
${ }^{194}$ Wiesner-Hanks, "Introduction”, 3; Susan Kinglsy Kent, "Gender Rules: Law and Politics," in A Companion to Gender History ed. Teresa A. Meade and Merry E. Wiesner-Hanks (Molden: Blackwell Publishing, 2004), 89.

${ }^{195}$ Fairchilds, Women in Early Modern Europe, 13.

${ }^{196}$ Dolen, "Gender and Sexuality," 14. Galen medical thinking was a medical school of thought which worked to compromise Classical medical knowledge with knowledge gained through studying anatomy and physiology. It also brought Muslim medical knowledge back to the West.
} 
feminine did. Gender has always been a social construction, and one that does not stay static.

In Early Modern Europe dependent males and married females were often subject to the same laws regarding land and privileges, and independent men and widows often shared the same rights and privileges as well. By the 1600s' standards of gender, the masculine was tied to financial and political independence, physical strength, authority, assertiveness, and morality; the feminine was tied to dependence, physical weakness, obedience and subservience, and immorality. ${ }^{197}$ Based on these criteria, therefore, feminine men and masculine women were not only possible, but probable. A young, unmarried noblewoman represented the extreme side of femininity. She was completely dependent on her family, and obedience to their wishes was expected. Ironically, although women were labeled as temptresses and tied to immorality by both major Christian religions at the time, women were also seen as being able to obtain a higher state of virtue than man, though it took considerable work to do so. ${ }^{198}$ Gender in the Early Modern Era was therefore less tied to biological sex than it was to financial, political, and social independence.

In parts of central and southeastern Europe, including Poland and Hungary, particularly capable women were held in high regard as the best wives, and were called viragos. Although the word virago today connotes a shrewish, nagging, unhappy woman, Early Modern Europe regarded viragos as strong, capable, women who were able to help ensure the family's financial survival by working outside the home, preventing their husbands from spending too much time and money on alcohol, and raising their children

\footnotetext{
${ }^{197}$ Kollman, "Self, Society, and Gender," 357; Madean, The Renaissance Notion of Women, 8.

${ }^{198}$ Madean, The Renaissance Notion of Women, 7.
} 
with proper Christian beliefs. ${ }^{199}$ While it would be exceedingly tempting to regard the virago as a "modern woman", this impulse must be avoided. For all women, including the viragos, attending to hearth and home was a duty, not a choice. Marriage and family was not something women did in addition to an outside career; it was their career. Even in cases where a woman's birth family was involved in craft guilds, she was discouraged, if not outright forbidden, from learning the trade for her own advantage. She was taught enough, directly or indirectly, to assist her husband, but as the worlds of home and business separated, women were excluded from business. Viragos should be seen less as women who were ahead of their time, and more as those who understood their place within the world and their marriage, and used the advantages and leverages they did have to their benefit. ${ }^{200}$

Although having many of the same characteristics, noblewomen were not considered viragos. ${ }^{201}$ Their authority was expected by virtue of their nobility, and did not have to be forged on its own. In this way, noblewomen were functionally a separate gender -- literate with some financial independence and political authority. Widowhood brought even more independence and authority to a noblewoman, since she inherited her husband's wealth and was legally able to use the lands he had left her however she saw fit. Despite this, there was never any doubt or question that she was regarded by her contemporaries as a woman and was not genderless, or unusual, especially if, while in power, she did not violate her socially constructed place as a wife and mother.

\footnotetext{
${ }^{199}$ Kimberly A. LaPrete, "Gendering Viragos: Medieval Perceptions of Powerful Women," in Victims or Viragos? Studies on Medieval and Early Modern Women Four, ed. Christine Meek and Catherine Lawless, (Portland: Four Courts Press, 2005), 24-26.

${ }^{200}$ LaPrete, "Gendering Viragos," 24-26.

${ }^{201}$ LaPrete, "Gendering Viragos," 37.
} 
Women in power who were able to maintain the appearance that their efforts in the political field supported their family were far more successful in their political goals and were received far more positively by their contemporaries than ruling women who did not. ${ }^{202}$ Between 1500 and 1800, women ruled England, Scotland, France, Spain, Russia, and Austria, but the idea of women in power was not a phenomenon that Early Modern Europe was forced to accept. How a woman in power should act, dress, and present herself to ensure that she had the most positive memory in history had been established the century before by Queen Isabella of Castile. In contrast, Caterina Sforza, countess of the Italian province Forli, provided a cautionary tale. Meanwhile, Catherine of Brandenburg exemplified how a woman could act properly and still not be accepted as a leader.

Queen Isabella of Castille, who ruled between 1474 and 1504, took on masculine roles such as leading troops and introducing her own legislation, which led to even her contemporaries being unsure about how to view her. ${ }^{203}$ Despite these masculine traits, she made sure to let the kingdom know that her husband was in charge as well. She sewed her husband's shirts, and taught her daughters needlework. When her husband was away she was sure to have a cadre of ladies sleep around her so that rumors of infidelity were not created. ${ }^{204}$ These actions served to comfort Castille; they were officially ruled by a queen, but she still stayed well within the boundaries of propriety for her gender.

In contrast, Countess Caterina Sforza, who ruled Forli from about 1488 until 1500, did not follow this model and as a result lost her political support when she began

\footnotetext{
202 Jansen, The Monstrous Regiment of Women, 20.

203 Jansen, Monstrous Regiment, 20; William Prescott, History of the Reign of Ferdinand and Isabella, The Catholic (New York: J.B. Lippincott \& Co. 1860), 184-185.

${ }^{204}$ Jansen, Monstrous Regiment, 22.
} 
to use her power for her own purposes. Her cruelty, ruthlessness, and even the gathering of troops, were all considered acceptable when they supported her husband and son. Caterina adopted very solidly a masculine model of ruling for herself, and by the time of her abdication, her sexual relationships and multiple secret marriages overshadowed any political good she had done. ${ }^{205}$

Over a century and across Europe, the model of Queen Isabella still carried weight, but did not always help. In 1629 Catherine of Brandenburg was elected prince of Transylvania after her husband died. The couple had no children, and despite an unhappy marriage, the clause in their wedding contract listed Catherine as his successor. Although she was educated and used to ruling due to her Hapsburg relatives, because she was ruling entirely on her own, accusations of arrogance, weakness, and immorality were frequently leveled at her. The Transylvanian Diet forced Catherine to swear additional oaths because she was a woman, requiring her to share power with a governor, which was usually only called for in Transylvania in cases where the ruler was a minor. Another oath forbade Catherine, who was twenty-seven and still able to bear children, from remarrying, stipulating that if she did, she would have to surrender the throne. This was so she could not start a new ruling dynasty. Catherine was therefore denied the chance to follow the largely successful model laid down by Isabella, using her position of authority to support her husband and sons, and with immense pressure for a male ruler due to the country being at war, she abdicated the throne in $1630 .^{206}$

\footnotetext{
205 Jansen, Monstrous Regiment, 44.

${ }^{206}$ Eva Deak, "'Princeps non Principessa': Catherine of Brandenburg, Elected Prince of Transylvania (1629-1630)," in The Role of Women in Early Modern Europe ed. Anne J. Cruz and Mihoko Suzuki, (Urbana: University of Illinois Press, 2009), 87-90.
} 
Most inherent in the ideas of femininity for Early Modern Europe was the combination of weak reason and strong passions. Women were perceived as being ruled by their emotions, which was why it was so important for successful women in power to prove that they had a male balance to rein in their emotions and counter their weak reasoning. ${ }^{207}$ Without this any woman, no matter her social or political standing, was subject to suspicion and scrutiny.

The idea that women lacked control over their emotions was supported by contemporary medicine. When the humeral theory of the body was revived and modified in the sixteenth century, it purported that women were cold and moist in contrast to men, who were hot and dry. ${ }^{208}$ While under the Classical understanding of this theory, men were immediately superior, in the revival, tempered by Galenic physiology, it was simply a fact of balance and was not immediately indicative of inferiority or superiority. But being cold and moist meant women were prone to feelings of moodiness and melancholy. This drove them to seek out dry warmth to counter these feelings, which then translated into sexual urges. $^{209}$

The notion that rule of emotion and desire for sex constantly distracted women, in turn, deemed them unfit for performing in public areas such as politics and war. This may have been a self-fulfilling prophecy. The first sorts of accusations leveled at women were charges of adultery and fornication. ${ }^{210}$ Unless there was undeniable evidence to counter the accusations, such as Isabella's honor guard of women, the rumors spread and became

\footnotetext{
${ }^{207}$ Madean, Renaissance Notion of Women, 51.

${ }^{208}$ Madean, Renaissance Notion of Women, 35.

${ }^{209}$ Madean, Renaissance Notion of Women, 8.

${ }^{210}$ Deak, "Princeps non Principessa", 81; DiCaprio and Wiesner, eds. Lives and Voices, 178; Bogucka, Women in Early Modern Polish Society, 63.
} 
regarded as a fact. Suspicions of infidelity or easy virtue could ruin a good engagement or lead to divorce, and the natural human inclination was to snuff out these rumors as quickly as possible. This shift in focus distracted from handling public matters. In the matter of the home, however, wives were considered the ultimate authority. Noblemen in particular often re-married quickly after being widowed because the demands of running a house were simply too much. ${ }^{211}$

Marriage itself was yet another reason women were considered unfit for public office. Not only was a wife's first duty to her husband, but a son-in-law had the potential to take away land from the family. ${ }^{212}$ Since land ownership was the basis of nobility and power, it was wise to keep as much land as possible within the family. Daughters in Hungary were given moveable items or cash, known as the daughter's quarter, or filial quarter, rather than land. ${ }^{213}$ According to the Tripartitum, the filial quarter came from the value of "... all the paternal property rights, together with all their revenues and appurtenances of any kind..." which was divided by four and given in a "...single payment to all of the daughters, and only in case and not in marketable chattels."214

There were only a few extreme circumstances in which a woman could inherit land from her father or blood male relatives in Hungary. The first was in cases where there were no direct male heirs and the land would go to another branch of the family, effectively ending a noble line. In this case the father could petition the king to allow him to name his daughter as heir. ${ }^{215}$ If the king agreed, the daughter owned the land outright,

\footnotetext{
${ }^{211}$ Fairchilds, Women in Early Modern Europe, 107.

212 Rady, Nobility, Land and Service, 103.

${ }^{213}$ Rady, Nobility, Land and Service, 103.

${ }^{214}$ Werboczy, Customary Law, 173; Rady, Nobility, Land and Service, 103.

${ }^{215}$ Rady, Nobility, Land and Service, 106; Fugedi, The Elefanthy, 27.
} 
and the family line continued from her descendants. ${ }^{216}$ On paper, she was regarded as a man without any actual confusion of her biological sex or her gendered duties. Records of this happening were rare, but cases did exist.

The second way a Hungarian woman could own property outright was by marrying an approved commoner. In this case, marrying a non-titled man meant the bride lost her title as well, weakening the potential pool of those who could inherit. ${ }^{217}$ In this case, to protect her nobility, she was given her daughter's quarter in land so she could keep her noble rank. ${ }^{218}$ This land, however, could not come from the original royal donation. If the daughter's quarter was given in land, it was from land that the father had purchased separately. ${ }^{219}$ The only way a daughter was given control of royal donation lands was if she had been recognized as an heir by the king.

Widows had a significantly easier time gaining and holding land, particularly if they were menopausal. Most obviously, they had inherited their husband's estate. Wills often contained very specific instructions on how money generated from lands was to be used to keep a widow comfortable throughout the rest of her days. ${ }^{220}$ Control of her late husband's land may have only been temporary, however, since the eldest surviving son was the true heir. This was true in the case of Bathory. When Francis died, Paul was only six years old, well under the legal age of fourteen which would have allowed him to take over. Although Bathory was not Paul's legal guardian, she continued to travel and

\footnotetext{
${ }^{216}$ Rady, Nobility Land and Service, 105.

${ }^{217}$ Werboczy, Customary Law, 91.

${ }^{218}$ Rady, Nobility, Land and Service, 104; Fugedi, The Elefanthy, 28; Werboczy, Customary Law, 91-

${ }^{219}$ Fugedi, The Elefanthy, 29.

${ }^{220}$ Fugedi, The Elefanthy, 25.
} 93. 
administer the estates, likely in her son's name, and fulfilled her prescribed role as a mother. $^{221}$

The more likely route to landownership for women was through the dower. Not to be confused with the dowry or trousseau, which was a customary gift given by the bride's family for the bride to give to the groom, the dower was a legal requirement and was directly from the groom to the bride. ${ }^{222}$ The definition from the Tripartium for dower was, “... a payment which is usually given to women who are lawfully married for performing the marriage dues, out of her husbands' goods and property rights, as the status of the husband demands."223 Ideally the dower was land and estates which belonged to his wife entirely and provided for her in her widowhood. In the case of Bathory, Francis gave her Cjesthe castle and the seventeen surrounding villages as her dower, a clear indication of the wealth the Nadasdy family controlled. ${ }^{224}$ She had full control of this property, the income was her own to dispose of as she wished, and she had the full right to give this land to whomever she desired in her will. This was why she relocated from Savar to Cjesthe after her husband's death; she retired there because it was hers. $^{225}$

${ }^{221}$ Thorne, Countess Dracula, 158.

${ }^{222}$ Fugedi, The Elefanthy, 25; Claire de Trafford, "Share and Share Alike? The Marriage Portion, Inheritance and Family Politics," in Pawns or Players: Studies on Medieval and Early Modern Women ed. Christine Meeks and Catherine Lawless (Dublin: Four Courts Press, 2003), 36.

${ }^{223}$ Werboczy, Customary Laws, 175.

${ }^{224}$ Thorne, Countess Dracula, 93; Craft, Infamous Lady, 35; Penrose, Bloody Countess, 39.

${ }^{225}$ It should be noted that even before this dower, Bathory was already in possession of an astonishing amount of wealth from her own filial quarter, recorded in 1572 after her engagement was official, which included but was not limited to: 31,000 florins, place settings for six gilded in gold and silver, a golden carpet set with jewels, 13 tapestries, and a gold and silver trimmed fur coat. There were also 19 named pieces of jewelry, including 11 pieces specifically for maidservants, and 339 pearls, diamonds, rubies, and sapphires. Thorne, Countess Bathory, 104. 
Marriage was such an imperative part of a noblewoman's life that at her engagement, her childhood was considered over. Marriage patterns changed depending on locale and social standing, from age of marriage to where the couple would live. Hungary, like most of Eastern Europe, was patrilocal; the bride moved into the groom's home. Nobles traditionally married sooner than the lower classes, between the ages of twelve and fourteen for girls and closer to the age of twenty for boys, and Hungary was no exception. Bathory herself was engaged at the age of ten after being chosen by the fifteen-year-old Francis Nadasdy. ${ }^{226}$ While their marriage certainly had political advantages, Francis was merely informed that he was given first choice if he wanted her as his bride and he agreed. It was hardly a sweeping romance, but it supported the rumors of her beauty, capability, and intelligence.

The main duty of a wife, noble or otherwise, was to provide her husband with children who would carry on the family name and increase the family's prosperity. A noble women also had the duty to make her husband look good. This could be done in a variety of ways, most importantly through good manners, good looks, and good counsel. As the royal court continued to grow in size and importance, manners and looks carried more and more weight. The same was so of education and the ability to make intelligent opinions and witty replies, which contributed immensely to the importance of educating women as previously discussed. ${ }^{227}$

With Bathory, appearance and vanity were unavoidable topics since the basic myth of Bathory was that she sought eternal youth by bathing in the blood of virgins. While she was not the first powerful Hungarian woman to be linked to a quest for beauty,

\footnotetext{
${ }^{226}$ Thorne, Countess Bathory, 88.

${ }^{227}$ Madean, The Renaissance Notion of Women, 64.
} 
she was certainly the most infamous. ${ }^{228}$ Aside from allegedly seeking eternal youth through the blood of others, the Enthusiasts accused her of being vain, changing her clothes several times a day, spending hours at her toilette, and taking grievous offense if the final result of all this work was flawed in any way. ${ }^{229}$ Wagner, who first made the claim in writing of her extreme vanity, may have written this to use Bathory's image as an example of all that was wrong with nobility, but there was some truth to her focus on appearance and desire for perfection. According to testimonies, seamstresses and handmaids were the frequent targets of her abuse. ${ }^{230}$

But Bathory was not alone in her obsession of vanity and personal deportment. With the growth of a court society, appearance, dress, and beauty were more of a concern for all nobles in Early Modern Europe. Throughout the Early Modern Era, physical beauty and a presentation of health through clean clothes became much more important. To change clothes several times a day was both normal and expected. ${ }^{231}$ Associations with hot water weakening the body and the widespread belief that using public baths spread diseases meant that bodies were not often cleaned, which also explained the spike in perfume use. ${ }^{232}$ But while bodies did not have to be clean, clothes did, hence the

\footnotetext{
${ }^{228}$ In the thirteenth century, an unnamed Hungarian queen was credited with the creation of the astringent now called Queen of Hungary Water. Recipes for the product are widely available on the internet, but the main ingredient is apple cider vinegar. Anna B. Bond, "The Queen of Hungary Water Recipe," Care2, August 31, 1999, accessed January 10, 2014, http://www.care2.com/greenliving/thequeen-of-hungarys-water.html.

${ }^{229}$ Baring-Gould, The Book of Werewolves, 139; SeGrove, Women Serial and Mass Murderers, 21.

${ }^{230}$ Thorne, Countess Dracula, 4; McNally, Dracula Was A Woman, 12.

${ }^{231}$ DeWold, The European Nobility, 166.

${ }^{232}$ Richard Carson, Fashions in Makeup: From Ancient to Modern Times (New York: Universe Books, 1972), 99.
} 
frequent wardrobe changes. Physical beauty and good looks were also tied to health, which was inevitably tied to the ability to bare strong children. ${ }^{233}$

High standards of beauty are regarded as a modern creation by magazines filled with airbrushed models triggering body image disorders and surgical ventures to "correct" nature, but the pressure of appearance was also high in the Early Modern Era. The beauty ideal came from Italy and was blonde hair, a high clear brow, small red lips, large eyes, a slight double chin, pink cheeks, and pale skin - which should, according to writers, be achieved without the aid of cosmetics. ${ }^{234}$ Despite the assertion of church officials regarding the sinful vanity of make up, cosmetics saw their highest use since the ancient world in the Early Modern Era. ${ }^{235}$ Wigs or dyes made dark hair blonde, white powder on the face and neck achieved the desired pale look, rouge was used on lips and cheeks, and hair was shaved or plucked to make the forehead larger and clearer. Eye shadow and mascara were not commonly used. ${ }^{236}$ The beauty ideal was supposedly based on Lucrezia Borgia, and powerful women continued to influence the standard of beauty throughout Europe. For example, when Elizabeth I took the throne, red hair and red wigs became vogue over blonde hair in England. But the ideal was not exclusive; Bathory herself met only a few of the criteria for it.

No written description of her appearance has been saved or found, but from the one confirmed portrait of Bathory that exists, it was clear that she rejected blonde hair from the start. Her portrait showed a woman with very dark hair and eyes. She was most

\footnotetext{
${ }^{233}$ Bogucka, Women in Early Modern Polish Society, 118.

${ }^{234}$ Carson, Fashions in Makeup, 93.

${ }^{235}$ Carson, Fashions in Makeup, 93; Nevile Williams, Powder and Paint: A History of the Englishwoman's Toilet, Elizabeth I - Elizabeth II (London: Longmans Green and Co, 1957), 1.

${ }^{236}$ Carson, Fashions in Make up, 127.
} 
certainly pale, which her portrait suggested was natural from the faint blue veins near her temple, but may have been augmented with make up. Her forehead was high and clear, probably from plucking or shaving the hairline back. Her brows were perhaps a bit thicker than conventional beauty allowed, but her eyes were large and her lips small and pink. A slight double chin was not clearly painted, but round, almost cherub like cheeks, hinted at the existence of one. How much and what type of make up she used has been left up to speculation, since anything resembling a list or a make up case for her has not been recovered or recorded. According to Penrose, she used make up made from sheep trotters, but that was a very unusual cosmetic base. ${ }^{237}$ Most facial powders were made with white lead, borax, pig jaw bones, or bear grease. ${ }^{238}$ If Bathory did use sheep trotters, it was a personal recipe and not something that was widely done. Cosmetics at this time were manufactured for sale in urban areas, but in less urbanized states, such as Hungary, it was made by hand for immediate use, usually by maids. Therefore the recipes for the cosmetics varied based on financial and geographical limitations.

Bathory's focus on appearance was a personal one, not to impress courtiers. While she attended court in Vienna, her attendance was infrequent and poorly documented. She was presented to Rudolph II, and the two supposedly got along famously over a mutual love of alchemy, a few years after her marriage. However, the next confirmed appearance at court was a month after she became a widow. This appearance at court so soon after Francis' death was the single recorded falter in an otherwise supportive, dutiful, respectful marriage.

\footnotetext{
${ }^{237}$ Penrose, Bloody Countess, 26.

${ }^{238}$ Carson, Fashions in Makeup, 103; Williams, Powder and Paint, 16; Sally Pointer, The Artifice of Beauty: A History and Practical Guide to Perfume and Cosmetics (Phoenix Mill: Sulton Publishing Limited, 2005), 96.
} 
Custom dictated that she should have remained isolated for a year after Francis' death, and that for the rest of her life she should have worn black. ${ }^{239}$ Instead, Bathory spent the equivalent of over a million dollars today on new clothes for herself and her servants, with popular belief arguing that the color she chose was red. ${ }^{240}$ The purchase of red clothing over black, the traditional mourning color, was taken as a sign she was celebrating her freedom from marriage, but the association of red with celebration, and sexuality, was a Western one. Folk custom of Hungary held red to be a color of mourning and protection from supernatural harm. ${ }^{241}$ Since Bathory did not keep strong ties at court, judging from her (at best) spotty attendance and decision to keep her children away from court training, it was likely she adopted some rustic traditions rather than Western court traditions. Indeed, lack of attendance at court for any noble marked them for criticism as a bumpkin. ${ }^{242}$ Bathory may also have felt she had already done her mourning duty since in 1601, a few years before he actually died, Francis fell gravely ill. What he suffered from was unclear, but it left him bed ridden and helpless for several months, and even though he did eventually return to the battlefield, by his return home in winter of 1603 he was once again unwell. ${ }^{243}$ This time he did not recover, dying in January of 1604. During his illness in 1601, Bathory may have prepared herself for mourning and did not feel a particular need to drag it out further. Her reasons for ignoring the isolation custom will, of course, remain speculation since no evidence has yet surfaced to offer an explanation.

\footnotetext{
239 Thorne, Countess Dracula, 108; Craft, Infamous Lady, 74-75.

${ }^{240}$ Craft, Infamous Lady, 75.

${ }^{241}$ Tekla Domotor, Hungarian Folk Customs (Budapest, 1972), 67.

242 DeWold, European Nobility, 45.

${ }^{243}$ Thorne, Countess Dracula, 106; Craft, Infamous Lady, 67, 69.
} 
Perhaps in the grand tradition of noble exceptionalism, Bathory did not feel she needed to explain.

Until that time, however, no evidence suggested that Bathory and her husband were an unhappy couple or negligent towards each other. Both were raised with Protestant beliefs, although Francis was Lutheran and she was Calvinist, so a divorce was possible with certain restrictions. The ten years it took the couple to have their first child was taken by the Enthusiasts to indicate a lack of interest in Francis's part or fertility problems on Bathory's. Most noble marriages produced a child within the first year or year and a half, so the case stood out as unusual. ${ }^{244}$ Why exactly procreation was so delayed has been left to speculation, but some theories can be disregarded with a wider view of context. The first to be set aside was lack of interest on the part of Francis: he chose her, and the duties that entailed were known to both parties. Not at least attempting to conceive was grounds for divorce, and would have damaged his reputation severely. ${ }^{245}$ If lack of interest was at the root of the delay, that it did not result in a divorce meant both sides lacked interest.

Infertility on the part of Bathory was also unlikely. While the rumors of a child out of wedlock circulated by von Elsburg, Penrose, and McNally were unsubstantiated at best and a flat out lie at worst, infertility was grounds for divorce, particularly among nobles. Since there was no divorce, there may have been a string of unrecorded still births or miscarriages. Still births and miscarriages did not always put the mother in severe risk, but was evidence of her fertility and prevented a divorce on those grounds. Neither still

\footnotetext{
${ }^{244}$ Peter, Beloved Children, 42.

${ }^{245}$ Lloyd Bonfield, "Developments in European Family Law," in The History of the European Family Volume One: Family life in Early Modern Times, 1500-1789 ed. David I. Kertzer and Marzia Barbogli (New Haven: Yale University Press, 2001), 110; Fairchilds, Women in Early Modern Europe, 200.
} 
births or miscarriages were recorded in the family records. In Hungary, large gaps

between births indicated miscarriages, still births, or the mother choosing to breast feed on her own over using a wet nurse. The other explanation for the lack of a divorce based on infertility was that Francis was simply that devoted. This too was unlikely. Francis himself was an only child and if he had no children upon his death, the Nadasdy lands would have gone to a cadet branch or back to the care of the throne. Francis Nadasdy needed children and if Bathory was unable to provide them, he needed to make other arrangements. $^{246}$

The most likely reason for the decade long delay was embarrassingly comedic poor timing. Francis was away on campaigns against the Turks for much of their marriage, at least nineteen years, so conception needed to be achieved in a very small window of time; in fact according to Thorne, he was only home for the Christmas season. ${ }^{247}$ Once the timing had been figured out, however, three daughters and two sons were born in very quick succession. While they lost one daughter and a son in infancy and youth, three children survived into adulthood and married. ${ }^{248}$

Rumors of infidelity have surrounded both husband and wife. ${ }^{249}$ Bathory was believed to have had affairs with both sexes, and to have carried on a long affair with a servant in Cjesthe. ${ }^{250}$ Francis supposedly had a bevy of mistresses, which kept him too

\footnotetext{
${ }^{246}$ Astute students of the Bathory legend would rightly point out that Francis' father, Thomas, was in the same boat and did not - as far as is known - take a mistress or adopt a child. The difference was that Thomas and Ursula Nadasdy were one of the rare examples of nobles who actually loved each other when they married. In contrast, Bathory and Francis were a political match whose feelings towards each other have never been reliably established.

247 Thorne, Countess Dracula, 117.

${ }^{248}$ Craft, Infamous Lady, 52, 192.

${ }^{249}$ Penrose, Bloody Countess, 31; Thorne, Countess Dracula, 107, 117.

${ }^{250}$ Gabriel Romay, The Dracula Myth (New York: Macmillan Publishers, 1975), 102; Penrose, Bloody Countess, 31; Peter, Beloved Children, 50.
} 
distracted to care what his wife was doing. ${ }^{251}$ Mistresses were not unknown for aristocratic men who married women they did not love and had no emotional bond to. Mistresses fulfilled the role of a companion, sex partner, and friend, and very often were an open secret. ${ }^{252}$ Aristocratic women sought the same aspects in their extra-marital partners. True extra-marital partners were not flings; they represented a significant investment in time, money, and emotion. ${ }^{253}$ If Francis and Bathory required physical pleasure, each had options, such as servants or prostitutes. The evidence needed to support claims of extra-marital affairs on either side, either long term or short term, has not been found. While Hungarian letters and diaries shied away from discussing sexual matters regarding marital partners, they were not so shy about discussing adventures with extra-marital partners. ${ }^{254}$ Adultery was grounds for divorce, if the innocent party demanded one; and accusations of adultery and fornication were popular ways to discredit other nobles, even posthumously, and like most scintillating stories stuck around far longer than they should have. All of this means that if they were having affairs, Bathory and Francis did not talk about them, did not write about them, and they were both having them so neither party could demand a divorce. Without evidence either way, any discussion of the happiness of their marriage is speculation, but their letters to each other more strongly suggest a mutually respectful marriage. They did not have the playful, flirtatious, correspondence shared by Thomas and Ursula, who gave each other

\footnotetext{
${ }^{251}$ Penrose, Bloody Countess, 31.

${ }^{252}$ Eleanor Herman, Sex with the Queen: Nine Hundred Years of Vile Kings, Virile Lovers, and Passionate Politics (New York: Harper Perennial, 2007), 1.

${ }^{253}$ Herman, Sex with the Queen, 4.

${ }^{254}$ Peter, Beloved Children, 39-40.
} 
pet names (Thomas called himself Ursula's “old grey vulture”). ${ }^{255}$ Instead their letters were more typical of conventional couples of the time with Bathory calling herself his servant and devoted wife. ${ }^{256}$ Francis, for his part, was a respectful husband who put his wife's needs before his own. In a letter to Mikilos Palffy, Francis wrote "Immediately I went to go to Your Grace, but my wife was found sick. I think, nevertheless, that by the Lord God there is no holiday to be had for me, and that I cannot go to the feast.",257 Bathory's letters to her husband usually followed a formula of submissive obedience and deference, "I command my service to your mercy. They have brought some letters to me which I include in my letter to you. May the Good Lord keep you in good health..." but she was not always so passive. ${ }^{258}$ Upon finding out that Francis was considering a military position in Transylvania, she made her outraged opinion of the matter clear, and afterwards it was never spoken of again:

I understand from your lordships' writing that you were almost sent to Transylvania, and everyone wonders at this since you can enjoy no good from Transylvania, and the soil from which you take all good things is this soil. We are at a loss to understand this news which I heard first from a friend who wrote of it to me and I have suffered bitterly of this... ${ }^{259}$

The land holding, political power, and financial comfort that went along with nobility clashed with the Early Modern European view of submissive, dependent

255 Thorne, Countess Dracula, 119; Craft, Infamous Lady, 22.

256 Thorne, Countess Dracula, 129.

${ }^{257}$ Craft, The Private Letters, 114.

258 Thorne, Countess Dracula, 119.

${ }^{259}$ Thorne, Countess Dracula, 119; The letter has an alternate translation, provided by Craft which carries an angrier tone: "I found out from a letter of His Majesty that you went from Vas...to Transylvania, and I find that very surprising, since nothing good can come from Transylvania. The same land from which we collect the harvest is also the land from which we receive bad news. All are surprised about this, because you did not take possession of any property in Transylvania. You live from the yield and fat of this country, so why did you leave this country? We do not understand this, as we have learned from the first letter of our friend, about which I wrote, who highly questions me. This has affected me very much, and when I heard it, I was very bitter. God maintain your health.” Craft, Infamous Lady, 45. 
femininity, so that the noblewoman was nearly a separate gender. Yet noblewomen were expected to be noble second and women first. Their main duty was to their husband and children and so long as they retained at least the image of doing so, other, more masculine actions, were ignored or forgiven. Bathory was more than up to the challenge as she fulfilled her role in regards to caring for her husband and children. She continued administering the estates for her son and saw to her daughter's future through good marriages. Even in the moments where she was upbraiding her husband, she did so because she was concerned for the success of the family. Because she continued to maintain her socially prescribed role, she was not seen as posing a threat to Thurzo, or Matthias. Since she was not a threat, there was no reason for the authority to target her based solely on her gender. The belief that there was a conspiracy against the Countess based on her place as wealthy widow does not take into account the general view of women in general in Early Modern Eastern Europe, and ignores that Bathory obeyed the socially prescribed roles and norms in her role as wife and widow. The expectations of Bathory as a woman were in fact so ingrained, that the mores and norms of femininity for Early Modern Europe extended even into her methods and targets for cruelty and violence. 


\section{CHAPTER IV \\ VICTIMS AND PERPETRATORS: \\ WOMEN AND VIOLENCE IN \\ EARLY MODERN EUROPE}

AND HUNGARY

Bathory achieved notoriety beyond her status as a noble for her crimes. She still holds the record for most successful female serial killer ever in the Guiness record books. Her violent attacks against female servants were compared to Jack the Ripper, and she stands as a symbol of madness, sadism, and aristocratic decadence. But beyond the initial shock of the sheer brutality, Bathory's crimes were a fascinating combination of Early Modern norms of female violence and methods of modern male serial killers. The laws of Hungary and the generally violent background of Early Modern Europe created an environment where many of her actions were actually expected and supported within the Early Modern code of public and private violence. Understanding the violence code helps illuminate some of the questions directly regarding Bathory's crimes, such as how she got away with such brutality for so long and why she targeted female servants.

Between the English Civil War, the religious wars triggered by the Reformation, the Thirty Years War, and numerous peasant revolts, the Early Modern Era was one of 
marked international violence. In Hungary specifically, the violence was considered particularly bad and countered the unifying effects of Occidental economic stimuli andproto-capitalism. ${ }^{260}$ The constant skirmishes with the Ottomans after 1520, the Fifteen Years War from 1591 to 1609 again against the Ottomans after the Peace of Zsitvatorok failed, the Peasant Revolt of 1514, and Bocskai's Rebellion all occurred within a century. The multiple wars wreaked havoc on rural and urban denizens alike, with abandoned villages leaving weak harvests and epidemics reducing the available workforce.

Interpersonal violence increased based on survival needs and anxiety. ${ }^{261}$ The interpersonal violence was exacerbated by epidemics, food shortages, economic trouble and ethnic tension. While the violence was usually a masculine prerogative, women were not isolated from experiencing and perpetuating violence. Hungary's violence was not contained to only the wars. Social, religious, and ethnic tensions exacerbated instances of and the need for personal violence.

Martin Fumee, a French political writer, wrote on the state of Hungary in 1600 with two goals in mind. The first was to motivate his fellow Christians into accepting and aiding the Hungarian refugees, mostly Magyar serfs or peasants, who entered Western Europe. The second was to bring the troubles of France into perspective; life may have been rough for the French peasantry, but at least they were not Hungarian. ${ }^{262}$ While not particularly violent in and of themselves, epidemics in Hungary were frequent and hard

\footnotetext{
${ }^{260}$ Kontler, A History of Hungary, 159.

261 Julius R. Ruff, Violence in Early Modern Europe, 1500-1800 (Cambridge: Cambridge University Press, 2001), 2; Hartmut Lehmann, "Under the Spell of Mars: Power Violence, and Mass Death in Seventeenth Century Europe" in Power, Violence, and Mass Death in Pre-Modern and Modern Times ed. Joseph Canning, Hartmut Lehmann and Jay Winter (Hampshire: Ashgate Publishing Limited, 2004 ), 95.

${ }^{262}$ Fumee, Historie, epistle.
} 
hitting, occurring at least once a decade. ${ }^{263}$ The most common diseases were small pox and the Hungarian Disease, which was either typhus or a strand of malaria. ${ }^{264}$ Occurring less frequently, but still more often than in the rest of Europe, was Bubonic Plague. ${ }^{265}$ The marching of armies across the country helped to spread disease, but the bigger problem was decidedly local. In an effort to escape the advancing armies of either side, peasants hid with their livestock in the swamps, where they contracted diseases and brought them home where they spread as life returned to normal. ${ }^{266}$ These epidemics reduced the number of available workers for planting and reaping, leading to famine, which was exacerbated by the Little Ice Age and the demands of the army. ${ }^{267}$ However, by 1600 , Hungary was a confederation of self sustaining demesne farms, and the food shortage was experienced mostly within the few urban areas of the country. ${ }^{268}$

More devastating to the Hungarians, regardless of social class, was the burst of the foodstuff bubble at the start of the seventeenth century. Previously, Hungary had uniquely situated itself, alongside Poland, as the bread basket of Europe. ${ }^{269}$ Wine, cereal grains, and (literally) enormous Hungarian cows were all sold at inflated prices across Europe. While Western Europe was starting down the road to industrialization, Eastern Europe settled into a firmly agrarian pattern and with food prices inflated nearly 300 percent, it was a profitable investment. ${ }^{270}$ Nobles like Bathory were able to secure

\footnotetext{
${ }^{263}$ Peter, "The Later Ottoman Period," 100.

${ }^{264}$ Cartedge, The Will to Survive, 10.

${ }^{265}$ Kontler, History of Hungary, 166.

${ }^{266}$ Peter, "The Later Ottoman Period and Royal Hungary," 100.

${ }^{267}$ Peter, "The Later Ottoman Period and Royal Hungary," 100; Wiazzo, "Mortality, Fertility and Family," 158; Lehmann, "Under the Spell of Mars," 95.

268 Zimanyai, Economy and Society, 31.

${ }^{269}$ Bogucka, Women in Early Modern Polish Society, 31; Palffy, The Kingdom of Hungary, 141; Peter, "The Later Ottoman Period," 104.

${ }^{270}$ Cartedge, Will to Survive, 96; Zimanyi, Economy and Society, 21.
} 
fortunes by excluding their serfs from the trade, increasing robot -- the work which was required of serfs -- for free labor, and avoiding tariffs through their noble status. ${ }^{271}$ When the bubble burst, due largely to the influx of food from the New World, Hungary was left with product which cost more to transport to markets than the profits it brought in. The solution for nobles was to turn to the local markets, forcing serfs to become consumers by ordering their tenants to sell only the castle's wines - no matter how bad the vintage was -- and reducing the time span when peasants could sell their own goods. ${ }^{272}$

Exacerbating the economic tension, ethnic and religious disputes boiled under the surface. During the Countess' life time, there was very little debate about religious freedom in any of the three parts of Hungary. The Ottomans had a fairly open policy of religious tolerance for any territory they conquered. In the Principality of Transylvania and Royal Hungary, the constant threat of Turkish invasion significantly reduced the perceived threat of a new, Christian, religion. Conversion to Protestantism happened with only a few isolated squabbles. When the Hapsburgs took control in 1526 Catholicism was promoted, but no actual laws were ever passed by the Diet which banned the religious practice of Lutheranism or Calvinism, despite the efforts of Rudolph II and Matthias II. ${ }^{273}$ To put it flippantly, there was very little concern about religion, unless one worshipped Allah.

But what the Hungarians avoided in religious conflicts was compensated with nearly constant ethnic battles. After the Battle of Mohacs in 1526, Hungary was divided into three parts. Skirmishes between Turkish forces and Hungarians were regular even

\footnotetext{
${ }^{271}$ Zimanyi, Economy and Society, 35.

${ }^{272}$ Cartedge, Will to Survive, 96; Zimanyi, Economy and Society, 35-36.

${ }^{273}$ Sugar, A History of Hungary, xii.
} 
during times of technical peace according to treaties, and only escalated with the Fifteen Years War. But even when the Turks were not the enemy, ethnic tensions were high. The excessive cost of holding back the Turks meant the Hapsburgs needed to import troops from the Germanic states. These troops largely took over the forts, and relegated their Hungarian compatriots to second class status. ${ }^{274}$ The actions of the Hapsburg troops reinforced the idea that the Hapsburgs helped Hungary only so Vienna did not fall to the Turks. ${ }^{275}$ Hungarians were not allowed to sell supplies to the troops, which may have eased the economic anxiety, but were expected to house the German mercenaries. Hungarian soldiers were under the command of Germanic superior officers. ${ }^{276}$ The Germanic soldiers usually did not speak Hungarian, and the Hungarians did not usually speak German. The Germanic knowledge of the territory was, unsurprisingly, inferior to the Hungarian; despite this, because the Hapsburgs were paying for the defense of the country, Germanic troops were in charge.

Ethnic tensions among the lower class were different, but no less problematic. In some ways they were more indicative of the level of violence Hungary experienced domestically than the problem with the soldiers. Even though it was controlled by the Turks, the fertile fields and large pasture lands of Ottoman Hungary were soon reoccupied, but not by Magyars. Croats, Slovaks, Romanians, and other ethnicities moved in where Magyars had abandoned and resettled the territories. ${ }^{277}$ The presence of the Slovaks was viewed as particularly insulting, and it only became worse when many of

\footnotetext{
${ }^{274}$ Szakaly, "Early Ottomen Period," 89; Cartedge, The Will to Survive, 101.

${ }^{275}$ Thorne, Countess Dracula, 129; Cartedge, The Will to Survive, 82, 99; Palffy, The Kingdom of Hungary, 4, 221.

${ }^{276}$ Szakaly, "Early Ottomen Period," 89; Cartedge, The Will to Survive, 101.

${ }^{277}$ Cartedge, The Will to Survive, 99.
} 
them were able to enter into Hungary's rather open nobility class. Thurzo himself was of Slovakian descent, and the majority of the Countess' victims were also Slovak. ${ }^{278}$ The war-weary Magyars were not only under threat of losing their whole state to one of two foreign powers, but they were also at risk of becoming ethnic, and therefore cultural, minorities as well. The international perspective was that Hungary was to be pitied, as well as be considered too violent and dangerous to travel to. ${ }^{279}$

Bathory's life after 1591 was chaotic, unsure, and confusing. She was not immune to the economic tensions, and since it was the duty of a noblewoman to aid the sick she was well aware of the personal trouble of her serfs. She was not raised in a violent environment, but she suddenly found herself in one. Bathory's infamy was based on the extreme actions she took against her servants. But were they truly so shocking and excessive within the context of Early Modern Hungary? Against the background of international violence, how was interpersonal violence affected? And how great was Bathory's deviation within the scope of individual conflict?

Violence was such a recognized and accepted part of life in Early Modern Europe it had its own codes. ${ }^{280}$ Interpersonal violence, defined as any violent act outside the parameters of war or judicial punishment, could be public or private, and depending on the sphere, the code of conduct changed. In public, violence was kept to the same gender -- a man attacked a man, and a woman attacked a woman -- but it was also between those of the same social standing. ${ }^{281}$ So a non-noble never confronted a noble in public, even if

\footnotetext{
${ }^{278}$ Peter, Beloved Children, 63.

${ }^{279}$ Fumee, Troubles of Hungarie, 2.

${ }^{280}$ Ruff, Violence in Early Modern Europe, 129; Michael R. Weisser, Crime and Punishment in Early Modern Europe (Atlantic Highlands: Humanities Press, 1979), 3.

${ }^{281}$ Dean, Crime in Medieval Europe, 77.
} 
they were both men. The rule of non-confrontation did not exactly translate from noble to non-noble, but it was considered uncouth for a noble to physically assault or abuse someone of lower standing in public. ${ }^{282}$ Therefore public violence, generally physical assaults, took place between the same sex and the same social standing. One example of this was duels, which were a type of public violence only performed between noblemen.

Aside from public confrontations only occurring between the same gender, violence codes also decided where the violence struck, and even what weapons were used. For men conflicts were typically about business or honor. ${ }^{283}$ The terms of the conflict were openly stated and an ultimatum was issued. Men were prepared with weapons, usually blades instead of blunt weapons, and their strikes targeted the head and vital organs. ${ }^{284}$

An example of male public violence in southern France in 1739 elegantly encapsulated most of the codes of male violence described above. Two merchant brothers, Pierre and Jean Lavialle were drinking when a man who owed Pierre money, Fouignet-Sauvel, entered the tavern. When Pierre publicly demanded repayment, violence quickly followed. Pierre struck Fouignet-Sauvel on the head with his walking stick. In response, Fouignet-Sauvel drew a knife, killing Pierre and wounding Jean. Afterwards, Fouignet-Sauvel fled and did not return to the area until 1741 after receiving a royal pardon. ${ }^{285}$

Striking the head was a particular affront to male honor, and therefore targeting it led to an escalation in violence. This was why decapitation was the preferred form of

\footnotetext{
${ }^{282}$ Weisser, Crime and Punishment, 20;Vronsky, Female Serial Killers, 88.

${ }^{283}$ Dean, Crime in Medieval Europe,77; Ruff, Violence in Early Modern Europe, 76, 117.

${ }^{284}$ Ruff, Violence in Early Modern Europe, 118-119.

${ }^{285}$ Ruff, Violence in Early Modern Europe, 118.
} 
execution for nobles; the loss of the head represented a complete lose of honor. Both men were aware of the debt between them, but it was only after the debt was announced that violence ensued. Public violence therefore was not only a way to save face, but was also an acceptable solution to personal conflicts. ${ }^{286}$

Violence between women was underreported, and was not considered a threat to public safety. As a result, information on women as perpetrators of violence was difficult to find, but not unheard of. In Haute Auvergne, a mountainous French province which, like Hungary, was agrarian based, two sisters were charged with murder in absentia when they allegedly stoned a man out of a cherry tree and proceeded to beat him to death. ${ }^{287}$ Two women attacking a man was unusual since, “...most violence and bad language for which women were responsible was directed at other women, not men."288 A fight between two women usually began with insults hurled at each other in a marketplace or other open common area. ${ }^{289}$ Invariably the insults surrounded sexual fidelity and the moral reputation of the parties, again because these elements were specifically important to women. Weapons were rarely used, since women preferred to slap, bite, or scratch, but when objects were involved they tended to be bludgeoning rather than bladed. ${ }^{290}$ Blows and strikes landed less on vital organs and more on areas associated with childbirth or beauty, such as the thighs, loins, hips or breasts and the face. ${ }^{291}$ Like men, public violence was geared towards saving face or honor, however very rarely did a fight between two

\footnotetext{
${ }^{286}$ Ruff, Violence in Early Modern Europe, 122; Malcom Greenshields, An Economy of Violence in Early Modern France: Crime and Justice in the Haute Auvergne 1587-1664 (University Park: The Pennsylvania State University Press, 1994), 2.

${ }^{287}$ Greenshields, Economy of Violence, 64.

${ }^{288}$ Nicholas, The Domestic Life, 21.

${ }^{289}$ Ruff, "Popular Violence and its Prosecution in Seventeenth and Eighteenth Century France," 33.

${ }^{290}$ Dean, Crime in Medieval Europe, 77.

${ }^{291}$ Ruff, Violence in Early Modern Europe, 123.
} 
women result in death, which explained why it was not considered a threat to the social order.

These codes of conduct, however, only applied to public displays of violence. Private violence, such as the correction of servants, wives, or children was also an accepted part of life in Early Modern Europe, and functioned by its own rules. ${ }^{292}$ In private, nobles disciplined their servants as they saw fit, and beatings were considered necessary since servants were deemed more unfit specimens of humanity. ${ }^{293}$ Paradoxically, because a noble was considered better, it was expected that punishments were meted out appropriately and did not maim or kill the servant. ${ }^{294}$ Because it was uncouth to attack a servant publicly, there were rarely witnesses to the corrections. Therefore only the results were seen, not the act. If the beatings did not prevent recidivism, the servant was dismissed. Legal action was rarely taken against servants -unless it was proven that they were the perpetrator in more than one domestic post. ${ }^{295}$ In Hungary, servants were not allowed to bring charges against a noble. ${ }^{296}$ This was advantageous to Bathory since it allowed her atrocities to go on without any fear of retaliation.

Aside from the oiled paper trick taught to her by Francis, Bathory herself preferred black humor in the punishments she gave to servants. Benedek Dezso, a steward of Bathory's was able to give an account of one such punishment when he testified against her,

\footnotetext{
${ }^{292}$ Dean, Crime in Medieval Europe, 32

${ }^{293}$ Dean, Crime in Medieval Europe, 32; Werboczky, Customary Laws, 417.

${ }^{294}$ Weisser, Crime and Punishment, 20.

${ }^{295}$ Rublock, Crimes of Women, 30.

${ }^{296}$ Werboczy, Customary Laws, 417.
} 
Once, on one occasion, while traveling in the direction of Bratislava, Ferenc Zemptey gave Lady E. Bathory two potato pogacsa [a type of biscuit] to take along. The mistress gave these to the German girl to hold. The girl ate one and could therefore no longer present it. As a result, the mistress heated the other until it was very hot, and then shoved it, nearly flaming, into the girl's mouth. ${ }^{297}$

In this instance, Bathory almost perfectly followed the code of private violence. The punishment, though harsh, was painful but not in and of itself lethal. Dezso was not clear if he was a witness to this punishment, or if he was told about it later. Either way, allowing any witness was a breach of the code, but for Bathory it may not have mattered if all the witnesses were servants.

A woman as the target of crime was not a shock to Early Modern Europe. Women were often the scapegoats of a community due to their dependent status, and while individual women managed to achieve special considerations for their abilities, the perception of women as weak made them acceptable victims. Less discussed in Early Modern Europe, were women who perpetrated crimes themselves. Part of this was because the nature of the crimes women committed, generally theft or sexual deviation, were fairly benign in the face of some of the more shocking and spectacular crimes committed by men. Another reason was the "victim of society" argument, supported by feminist true crime writers, that women could not be considered criminals because their crimes were about survival, and men and their social positions pushed women to commit the criminal acts. ${ }^{298}$ A growing counter argument states that claiming women were forced into crime because of men robbed women of the very independence that the crime

\footnotetext{
${ }^{297}$ Craft, Infamous Lady, 57.

${ }^{298}$ Vronsky, Female Serial Killers, 6.
} 
signified they had. ${ }^{299}$ Both arguments have merit; certain crimes regularly attributed to women were usually only committed out of a sense of desperation, but others were not. Bathory's murder of her female servants after extended sessions of brutal torture was not done out of a sense of desperation - there was no social pressure on her to beat, maim, and kill her servants; in fact, she was encouraged to do the opposite. Despite this, Craft believed her actions were due to an anxiety or stress disorder triggered by the demands of public appearances and her vulnerability as a widow. ${ }^{300}$ While Bathory was marginalized as a woman, she was not a threat because her son was her husband's legal heir. Her power was based on her role as an administrator for her son, and the only actual land she controlled was Castle Cjesthe. ${ }^{301}$

Female criminals did not usually resort to violence or public spaces for their crimes. While men were usually charged, according to court records, with crimes of physical violence like assault, battery, or public drunkenness, women were usually charged with theft or sexual deviation. ${ }^{302}$ Single, young, female servants were charged most often with theft. These girls were deemed especially untrustworthy because of the lack of a male presence of to control them. ${ }^{303}$ Female thieves stole small, expensive items like décor or jewelry and then sold them for cash. ${ }^{304}$ Very rarely was actual currency

\footnotetext{
${ }^{299}$ Vronsky, Female Serial Killers, 8.

${ }^{300}$ Craft, Infamous Lady, 93.

${ }^{301}$ For further discussion of Bathory's place as a noble woman and the limits of her power as a widow, see Chapter Three.

${ }^{302}$ Rublock, Crimes of Women, 13-14. Witchcraft, most certainly a crime frequently leveled against women, had a separate set of circumstances and procedures so those charges will not be treated here. Additionally, in Hungary, witchcraft as a criminal charge was not used to nearly the degree it was in Western Europe. It was not until 1614 that the first witchcraft trial was held in Hungary, and it was led by Germanic soldiers, not Hungarian religious leaders. Gabor Klaniczay, "The Accusations and the Universe of Popular Magic," in Early Modern European Witchcraft: Centres and Peripheries ed. Bengt Ankarloo and Gustav Henningsen (Oxford: Clarendon Press, 1990), 224.

${ }^{303}$ DiCaprio and Wiesner, Lives and Voices, 178.

${ }^{304}$ DiCaprio and Wiesner, Lives and Voices, 178.
} 
taken, but rather items which were easier to carry and conceal, and turned into currency at a later time. While the process of fencing seemed like an unnecessary step, there was a practicality to it. A brooch made of gold or with a few gems in it could be hidden in a petticoat and (literally) stay silent, while stealing the equivalent in coins was noisy and more difficult to hide. Additionally, thieves who made a habit of posing as servants to steal goods needed to make quick escapes to avoid the law, usually by crossing a border. Since currencies changed, having items to exchange for cash was far more practical than stealing coins.

But servants did occasionally steal coins; in fact Bathory herself had to handle such a situation, which she did with her usual exuberance. When Bathory caught a thief taking coins, she ordered that a coin be heated and then pressed it into the girl's hand. Again, this punishment was well within the code of private violence. Such a punishment did not maim or kill the servant, but if she was ever caught stealing again, she was marked and could face legal repercussions. ${ }^{305}$

As the story of Bathory's servant with the potato biscuit showed, theft was not always about material gain for women; it was also about survival. English court records and clerk reports abound with accounts of poor housewives stealing clothing off the line, bags of food from sheds, and even livestock. ${ }^{306}$ Usually the theft of a chicken or other small animal indicated immediate consumption of the animal. ${ }^{307}$ The intention of the theft of larger animals such as cows or horses was to sell them on the illegitimate market, and

\footnotetext{
${ }^{305}$ Craft, An Infamous Lady, 42; Thorne, Countess Dracula, 61; Penrose, Bloody Countess, 42.

${ }^{306}$ Cynthia J. Nevile, "War, Women and Crime in Northern English Border Lands in the Later Middle Ages," in The Final Argument ed. Kogay and Villalon, 167.

${ }^{307}$ Nevile, "War, Women and Crime," 168.
} 
carried a greater penalty. ${ }^{308}$ According to the Tripartitum, anyone who stole a horse or other livestock, or could not provide proof that he had legally purchased the animal, was hung. ${ }^{309}$ In England, thefts which were tied to basic survival usually concluded with the perpetrator being forced to issue an apology, and the victim being asked to forgive the theft and turn the other cheek. ${ }^{310}$ There was nothing written about theft for survival in the Tripartitum, but since landowners were also the judicial presence on their estates, this was likely handled locally. In her own estates, when Bathory discovered a girl had stolen a pear, the thief was stripped, tied to a tree in the courtyard, and covered in honey. She was left in the sun to be stung and bitten by insects. Since this instance happened while Francis was alive, it was unlikely the girl died from this, again meeting the code for domestic servant punishment. ${ }^{311}$

But not all girls were lucky enough to serve the Countess while Francis forbade punishments leading the death. An often repeated example of ironic servant punishment was the infamous ice bath. It was unclear if this occurred once or frequently, but it diverges significantly from Bathory's usual methods so it was likely used only when there was no other form of punishment. The ice bath was very simple: a girl was stripped and thrown outside in the winter and had buckets of water poured on her until she froze to death. ${ }^{312}$ Penrose claimed this was done to satisfy a sadistic urge and would occur en masse while the Countess watched. ${ }^{313}$ According to the trial records, however, the ice

\footnotetext{
${ }^{308}$ Nevile, "War, Women and Crime," 167-168.

${ }^{309}$ Werboczky, Customary Laws, 421.

${ }^{310}$ Nevile, "War, Women and Crime,"167.

${ }^{311}$ Craft, An Infamous Lady, 42; Thorne, Countess Dracula, 61; Penrose, Bloody Countess, 42.

${ }^{312}$ Craft, An Infamous Lady, 90; Thorne, Countess Dracula, 61, Penrose, Bloody Countess, 111.

${ }^{313}$ Penrose, Bloody Countess, 111.
} 
bath occurred infrequently and on the road. ${ }^{314}$ Rather than the manifestation of a sadistic need, Craft argued that the ice bath was punishment for a complaining servant who whined of fatigue, cold and thirst. Therefore the ice bath was likely intended to be a punishment, but ended up in death.

Bathory, however, was not accused of theft or the next most common charge against women, sexual deviance (though the latter was argued by von Elsburg and repeated by Penrose and McNally.) She was accused of murder. ${ }^{315}$ Murder was not a common charge leveled against women, but when it did happen, it too had very gendered perceptions and codes. As with other crimes, the charge of murder against women was usually for deaths caused in private and non-violently, using poisons over weapons, against members of their own home or family. Even today in a majority of cases with a murderess, the methods and motives echo those from the Early Modern Era. The methods were usually poisoning and the motives were money or duress. ${ }^{316}$ Duress as motive, particularly if it was well known that the husband was a poor provider, was viewed in a more lenient manner than murder for money. While Battered Wife Syndrome was not yet understood and the murderess was still penalized with exile or death, socially she was forgiven by the community. ${ }^{317}$ Women were to be subservient and obedient, but in return it was the job of men to provide food and shelter. Men who failed to fulfill their role were not only punished by the law, but also by the church. This recognition of desperate wives with drunk or spendthrift husbands did not equate to an acquittal, but the sentence may

\footnotetext{
${ }^{314}$ Thorne, Countess Dracula, 62.

${ }^{315}$ It is noteworthy that Katalin Peter, who wrote a monograph in Hungarian on the Countess, reported that she was charged with cruelty, not murder. This was inaccurate. Thurzo's charge against her was eighty counts of murder, not eighty counts of cruelty.

${ }^{316}$ SeGrove, Women Serial and Mass Murderers, 1-2.

${ }^{317}$ Rublock, The Crimes of Women, 4; Fairchilds, Women in Early Modern Europe, 202; DiCaprio and Wiesner, Lives and Voices, 184.
} 
have been mitigated to exile instead of execution. ${ }^{318}$ There was no such forgiveness for murder for money.

When women were charged with murder of any kind, they were more likely to be charged with infanticide over homicide. In this charge, some credit has to be given to the theory that women are only forced to commit criminal acts because of the injustices of a patriarchal society. By the Early Modern Era, infanticide was the act of a desperate woman who either could not keep her child, or needed to cover up its birth. ${ }^{319}$ These women included rape victims, the most extreme poor, or those who risked being charged with sexual deviance if the child was found. ${ }^{320}$ Infanticide was not the act of a married woman or an engaged woman, but a single woman, and it was rapidly declining as a practice in Western Europe with the spread of foundling homes. Further discouraging the practice, laws were passed across Europe that outlawed the killing of babies by mothers. However, since this was still a time of high infant mortality it was not always easy to prove that the mother had killed the child, rather than the baby dying of natural causes. Despite this difficulty, women were regularly charged with this crime and the penalty was execution. ${ }^{321}$ Interestingly, the Tripartitum was silent on laws regarding infanticide, or whether infanticide was considered murder. This may have been another example of local judicial jurisdiction.

Because, with the exception of infanticide, the charge of murder was rarely directed at women, Bathory's crimes have been of particular interest. But what were her

\footnotetext{
${ }^{318}$ Rublock, The Crimes of Women, 4; Fairchilds, Women in Early Modern Europe, 202; DiCaprio and Wiesner, Lives and Voices, 184.

${ }^{319}$ Herlihy, Women, Family and Society, 225-226.

${ }^{320}$ Herlihy, Women, Family and Society, 226; Watt, "The Impact of the Reformation," 150.

${ }^{321}$ Hardwick, "Did Gender have a Renaissance?" 349.
} 
crimes? The Enthusiasts have all described them, but the best summation was written by

Craft based on the testimony of the witnesses. According to Craft,

...what was perhaps most shocking were allegations of exactly

how these girls were being tortured and killed: washed with and made to roll in nettles; pins stuck into their lips and under the fingernails; needles jammed into their shoulders and arms; floggings on the breasts while held in chains; their hands, arms, and abdomens scorched with burning irons; chunks of flesh wrenched from their back with pliers; noses, lips, tongues, and fingers pierced with needles; mouths forced shut with clamps; flesh cut out of the buttocks and from between the shoulders, then cooked and served to them; flesh and private parts singed with candles; knives plunged into arms and feet; hands crushed and maimed; fingers cut off with scissors and sheers; red hot pokers shoved up vaginas; bodies beaten to death with cudgels; lashings until flesh fell from the bones; and girls made to stand naked in the cold, doused with water or submerged up to their neck in icy rivers. ${ }^{322}$

Penrose added that Bathory used a clockwork, or mechanical, Iron Maiden for her tortures and that girls were forced into spike lined cages hung from the ceiling. Once in the cages, the girls were jabbed with red hot pokers; if they dodged the pokers, they were stabbed with the spikes. ${ }^{323}$ While the cages were possible, the existence of the Iron Maiden was believed to be a myth until 1867, when one was found in an Italian basement. ${ }^{324}$ Based on this, it was unlikely that Bathory used this item simply because it was so rare and was not mentioned in the testimonies of the accomplices.

True crime writers wrote about Bathory as a serial killer before the concept of a serial killer was understood or labeled. For biographers of serial killers she was of further interest as a woman, and the idea that a woman could be a serial killer was believed

\footnotetext{
${ }^{322}$ Craft, Infamous Lady, 112-113.

${ }^{323}$ Penrose, Bloody Countess, 96.

${ }^{324}$ Brian Innes, The History of Torture (New York: St. Martin's Press, 1998), 134.
} 
impossible until Aileen Wuornos. ${ }^{325}$ There were three reasons why the possibility of female serial killers was discounted, none of which had to do with capability of killing. The first was the (still) unclear definition of a serial killer. Early definitions were based solely on the number of victims tied to a murderer who were not directly related to the perpetrator. ${ }^{326}$ The definition was adjusted to focus more on the motiveless aspect of the murder, and while there have been addendums and proposed adjustments; the motiveless element has remained, even though it is a misnomer. A traditional murderess killed for money, duress, or revenge. The serial killer kills to enact a fantasy or calm an urge, which is a motive at the very basic definition, but does not carry the same legal weight. A motive for murder included money, revenge, pride, or the poetic "crime of passion"; the killing of another human for the satisfaction of a fantasy or an urge is not included as a motive for murder by modern courts, and it was unthinkable to Early Modern ones.

Secondly, the target of serial killers differs from the practice of the traditional murderess. The serial killer creates the image of his victim before locating him or her. The victim may look a certain way or act a certain way, which fulfills the fantasy. The victim is always a stranger to the serial killer, existing only for the purpose of fulfilling the urge ${ }^{327}$ In contrast, traditional female murderers killed those close to them who were already subservient or weak, like children, ill relatives, or servants. ${ }^{328}$ Certainly in this

\footnotetext{
${ }^{325}$ Vronsky, Female Serial Killers, 3.

${ }^{326}$ Giannangelo, The Psychopathology of Serial Murder, 4; Donald T. Lunde, Murder and Madness, (San Francisco: San Francisco Book Company, 1976), 47; Ronald M. Holmes and James E. DeBurger, "Profiles in Terror: The Serial Murderer," in Contemporary Perspectives on Serial Murder ed. Ronald M. Holmes and Stephan T. Holmes (Thousand Oaks: Sage Publications, 1998), 6.

${ }^{327}$ Katherine Romsland, The Human Predator: A Historical Chronicle of Serial Murder and Forensic Investigations (New York: Berkley Books, 2005), xi; Colin Wilson and Donald Seamn, The Serial Killers: A study in the Psychology of Violence (New York: Carol Publishing, 1990), 2.

${ }^{328}$ SeGrove, Women Serial and Mass Murderers, 1.
} 
regard Bathory remained true to the stereotypical female killer, for her victims were all servants or those who were subservient to her.

Finally, the method of murder differed. Male serial killers often, though not always, use elaborate and painful techniques to kill the victim. There are some profilers who argue that death frequently was not the desired goal, but merely a side effect of living out the fantasy. ${ }^{329}$ The traditional murderess, on the other hand, sought to accomplish death from the very beginning. Her process was non-violent and relatively painless, generally with poison. Ideally the death was seen as natural. ${ }^{330}$

Female serial killers differ significantly from their male counterparts and from the traditional murderess. Like male serial killers, they target strangers and use violent methods to kill. ${ }^{331}$ Unlike male serial killers and more like the traditional murderess, the intent is always death. Profilers and legal experts have discussed and written about ways to avoid becoming a serial killer's victim, but the techniques discussed have only been proven for male serial killers. ${ }^{332}$ Female serial killers are not yet studied to the degree of their male counter parts, partially because of the debate about their existence, and partially because female serial killers do not talk about their crimes. They do not seek the press's attention and are reluctant to participate in studies. ${ }^{333}$ This reluctance makes Bathory's case even more important to true crime writers since she can be studied for the ways she did or did not meet the role of a serial killer. If true crime writers established

\footnotetext{
${ }^{329}$ Giannangelo, Psychopathology of Serial Murder, 5; Vronsky, Female Serial Killers, 23.

${ }^{330}$ Vronsky, Female Serial Killers, 33-34.

${ }^{331}$ Vronsky, Female Serial Killers, 41

332 Kelleher and Kelleher, Murder Most Rare, 73; Vronsky, Female Serial Killer, 37.

${ }^{333}$ Vronsky, Female Serial Killer, 46.
} 
Bathory as a true serial killer, it would serve as definitive proof that the female serial killer has always existed.

Bathory's crimes were a unique combination of both the current definition of the serial killer, and the Early Modern European conception of female violence. Because the motivation for these crimes was not isolated, or even agreed upon, Bathory has to be considered a serial killer for both the double (or possibly triple) digit body count and the apparent lack of motive for her crimes. Bathory targeted young female servants as her victims, which was consistent not only with the Early Modern European concept of female violence but also the understanding of female non-serial killers. The tortures were always done in private since they entailed a noble attacking a servant. Bathory performed her acts in the kitchens, bathrooms, and dungeons of her homes with the only witnesses usually being other female servants. ${ }^{334}$ Dezso was an eye witness to at least three murders and was able to recount the events when he was questioned for her inquest, which was translated and published by Craft in her book.

Among other things, the following shameful deeds were clearly seen by him with his own eyes: that the mistress took a shoemaker's daughter named Ilonka, stripped her naked and, in this way, cruelly tormented her by taking a knife and, beginning with the fingers, shoving the knife into both arms; thereafter, she flogged the girl, and then held a burning candle to her hands until they were burned and singed, torturing her until she put an end to her life. ${ }^{335}$

This particular murder deviated from the codes and standards of women in method and target. Bathory used a blade and a candle as well as the more expected flog to kill this particular victim. Instead of attacking parts of the body associated with beauty or

\footnotetext{
${ }^{334}$ Craft, Infamous Lady, 58; Penrose, The Bloody Countess, 56, 82.

${ }^{335}$ Craft, Infamous Lady, 285.
} 
birthing, Bathory adopted a very masculine method and attacked limbs associated with Ilonka's work, the hands and arms. Dezso was not clear how the girl died exactly, but she likely either bled or was burned to death. Either way, there was no way to claim this death was natural.

Dezso continues his description of the murders he saw. This time the victims were seamstresses, and Bathory's violence against them was much more traditional.

The witness has seen countless cases in which girls were made to stand naked before Lady Bathory as she beat them, many times beating them on the hands and nails so long that the became swollen and infected, and then she forced them to sew, commanding them, "Sew, you whore!" And if the poor girl with her broken hand could not sew because she was in such a pitiful condition, it led Lady E. Bathory to complain in front of her attendants: "What a useless, spoiled whore she is. She can't even sew!" And then she began to stick the girl with the needle from her arm up to her shoulder, thereafter whipping, flogging and tormenting her. ${ }^{336}$

Bathory's insults were within the realm of the violence code for women since it attacked and questioned the target's chastity and virtue. Bathory took the insults one step further and attacked the girl's skills as a seamstress. Although the Countess again attacked the hands and arms, she used bludgeoning instruments instead of blades as before. The use of a needle was unique, but echoes back to Bathory's use of ironic punishments; the seamstress can not sew, so mime stitching on her skin.

The steward recounted not only things he had seen himself, but also what he heard from others.

The witness also heard from others that the wide fire iron was heated and the girls' two arms burned to smoke and ash. Yes, we are also told that the

\footnotetext{
${ }^{336}$ Craft, Infamous Lady, 286.
} 
smaller, round fire iron was also heated until very hot and (on my honor!) shoved into their vaginas. ${ }^{337}$

Once again Bathory deviated in her instruments by using hot irons, but in more ways this example conformed to the violence code. Dezso did not witness this punishment directly, which means it was likely done in private or only witnessed by other women. And this time, Bathory attacked the genitals, conforming to the code of violence by targeting an area directly associated with childbirth. Dezso's testimony, one of the most detailed in the trial records, clarified the ways in which Bathory did and did not follow the code of violence. That she did suggests the gendering process was deep enough that it even guided her atrocities since she attacked subordinates, insulted their chastity, and used bludgeoning tools over blades. The times she did not follow the code supported the argument she was indeed a serial killer; her motives were not always clear, her methods were elaborate, and the goal was death.

Bathory's methods were bludgeoning and slashing attacks to the thighs, loins, and breasts as well as stabbing the lips, tongues, and under the nails of the girls with pins and needles. ${ }^{338}$ While the use of a bludgeoning weapon was within the standard female arsenal in Early Modern Europe, stabbing, cutting, and severing fingers were not. Some of Bathory's methods started out as discipline attempts, and then became torture. Seamstresses were frequent targets for fumbling a dress or pricking their mistress. Pricking or stabbing them for their misstep, while excessive to the modern mind, may have been ironic. Bathory employed similar ironic punishments to girls she did not kill.

But no matter what started the tortures, the end was the same for nearly all the

\footnotetext{
${ }^{337}$ Craft, Infamous Lady, 287.

${ }^{338}$ Craft, An Infamous Lady, 112-113; Thorne, Countess Dracula, 62. Penrose, Bloody Countess, 85.
} 
victims: they were beaten to death with blunt objects. This use of bludgeoning over more direct methods for the purposeful goal of death incorporates elements of the modern understanding of female serial killers and the Early Modern European concept of female and private violence. Violence was very familiar and common in Early Modern Europe, but the judicial system, supported by the growth of a stronger central government and a literate noble population was catching up. Bathory was very confident that the law would not be able to touch her because she was a noble, and perhaps she was correct, but changes in the judicial procedure of Early Modern Europe were not in her favor. 


\section{CHAPTER V \\ SPONTANEOUS TRUTHS AND THE POWER CENTER: \\ JUSTICE IN EARLY MODERN EUROPE}

The widespread violence of the Early Modern Era was countered by the growth of central authority, which included police and judicial systems. The sixteenth century experienced a population boom and the growth of urbanization, manorialism and fiefdom fractured and stronger monarchies filled the power vacuum. At the same time, the resurgence of Classical art and literature also triggered a return to written law codes based on Roman law instead of law based on oral traditions and memory of precedent. ${ }^{339}$ In Europe, borders solidified and the local power of nobles was eclipsed by the stronger, written law-centered, militarily supported central authority. Legal codes were a combination of Roman law, customary laws, and oral precedent on the continent and were the basis for ecclesiastical laws; in a very real sense church and state were the same law. In some cases, particularly those dealing with property or marriage, the local church acted on behalf of the state since its institutions already housed the deeds and sale contracts. ${ }^{340}$ A side effect of the stronger central authority was the reduction of the local power of the nobles. Power struggles between the two sides were frequent.

\footnotetext{
${ }^{339}$ Silverman, Tortured Subjects, 7.

${ }^{340}$ Fairchilds, Women in Early Modern Europe, 14; Wiesner, Women and Gender, 35; Stokes, Demons of Urban Reform, 5.
} 
While Hungary was in many ways very Western in terms of art and religion, it was distinctly different in politics. Although the best estimate for Hungary's population was a relatively sparse three million denizens, they were spread over an area of about 300,000 square kilometers. ${ }^{341}$ This population density, about thirty-two and a half people per square mile, meant that the kings of Hungary relied on the local power of the nobles to help keep order in the state. ${ }^{342}$ This balance was so needed that, in 1222 , seven years before the Magna Carta, the Golden Bull clearly laid out the duties and the balance of power between the nobles of Hungary and the king. ${ }^{343}$ Hungarian nobles kept this treaty strong, and it was revised no less than three times, the last time in 1317 , to reassure the nobles of those rights and privileges before the king. ${ }^{344}$

In 1514, an anti-feudal demonstration turned into a peasant revolt that was violently put down by the aristocracy. ${ }^{345}$ In the aftermath, the Tripartitum was written in 1517. This Latin document took the rights and privileges laid out in the Golden Bull and made them into the customary noble laws of Hungary. ${ }^{346}$ This was the country's law code until it was absorbed into the dual-monarchical state of Austria-Hungary in 1867. When Ferdinand I was elected to the Hungarian throne in 1527, there was an attempt to amend the Tripartitum by the Hapsburgs, but the Quadpartitum was never put into practice. ${ }^{347}$

This resistance against establishing a new set of laws from a new ruling family was just one example of the power nobles continued to hold in Hungary. The Diet

\footnotetext{
${ }^{341}$ Peter, "The Later Ottoman Period and Royal Hungary 1606-1711," 103.

${ }^{342}$ Peter, "Later Ottoman Period," 103.

343 Sugar, "Introduction," xi.

${ }^{344}$ Rady, Nobility, Land and Service in Medieval Hungary, 39, 54.

345 Pal Engel, "The Late Medieval Period, 1382-1526," in A History of Hungary, 79.

${ }^{346}$ Engel, "Late Medieval Period," 79; Palffy, The Kingdom of Hungary, 181.

${ }^{347}$ Palffy, Kingdom of Hungary, 189.
} 
retained full rights to elect the king, despite Hapsburg protests. ${ }^{348}$ In something of a compromise, the heir apparent to the Holy Roman Empire had the title King of Hungary if he received approval by the Hungarian Diet. ${ }^{349}$ What happened if the heir apparent did not receive the approval of the Diet was neither stated, nor was it ever an issue. The more important element of the election of a new Hungarian king was the oath he swore at his coronation. This oath reinforced the balance of power between the throne and the nobility including freedom of religion for nobles, voting rights on legislation, and judicial rights on their properties. ${ }^{350}$

Because of the early dualistic nature of Hungary's government, central authority did not develop as quickly as it did in other countries. Additionally, the Hapsburg family was stretched thin across Europe and regarded the sliver of Royal Hungary it controlled as important enough to make compromises. The monarch allowed the nobles to continue to control the country with only minimal interference. Because of this when dealing with Hungarian authority, the nobles always played a much stronger role than the king until 1867, well after the time of Bathory and her crimes. Unlike Western European nobles, Hungarian elite already saw themselves as a coherent unit which needed to work together. ${ }^{351}$ Despite this apparent cohesiveness, there was still a division among the nobles based on how many serfs worked the estates a noble owned. Controlling the land of one hundred or more serfs was powerful enough to make a noble a baron or a magnate. Barons and magnates paid no taxes and were eligible for all the rights and privileges listed by the Tripartitium. Nobles who owned land, but not enough to claim one hundred

\footnotetext{
${ }^{348}$ Palffy, Kingdom of Hungary, 181.

${ }^{349}$ Palffy, Kingdom of Hungary, 161-162.

${ }^{350}$ Palffy, Kingdom of Hungary, 181; Deak, "Princeps non Principessa," 86.

${ }^{351}$ DeWold, The European Nobility, xvi.
} 
serfs, were still nobles, but were lesser nobles who went by a variety of titles depending on how much land they owned. Nobles too poor to properly administer their estates, younger siblings or nobles otherwise not entitled to property could become servilias. A servilias worked as a clerk or other position for a more powerful noble family in exchange for room and board and maybe a small pension. Socially, this was not an embarrassing position for a lesser noble to be in, since there was the potential to marry or network towards achieving land. And it was better than becoming a commoner. Lesser nobles, however, did not benefit from the full privileges of the Tripartitium since they themselves paid their taxes, not their serfs. It was from the lesser nobility that Bathory's noble victims were from, and despite their reduced privileges, they were still nobles. While Bathory did not break the law killing her servants -- by the strictest definition they were considered a resource -- subjecting fellow nobles to the same treatment she violated their rights and privileges. Killing her students made Bathory guilty of murder under the Tripartitum.

The power of a magnate on his or her estates was all but absolute, and the Tripartitum reinforced this. ${ }^{352}$ While the Early Modern Era in Hungary was criticized for the re-establishment of serfdom, Hungarian serfdom did not function the same way as in Western Europe. Hungary did have serfdom during the Middle Ages, but loopholes existed for a serf to leave one noble and serve another. After 1517, this right was removed. A serf could still petition to leave, but a noble could claim the serf was a criminal and have him returned effectively without question. ${ }^{353}$ Serfs could also no longer own land, a right they previously had. Robot, or unpaid tenant labor, was not supposed to

\footnotetext{
${ }^{352}$ Werboczy, Customary Laws, 57.

${ }^{353}$ Zimanyi, Economy and Society, 37.
} 
exceed fifty-two days a year, but many nobles quadrupled the amount of time they demanded from their tenants to profit from the agricultural boom. Bathory was not one of them; instead she raised taxes. ${ }^{354}$ Complaints regarding landlords could be sent to the Diet, but there was no real motivation for the Diet to correct what was an open, and highly profitable, practice. Bathory herself had two work complaints lodged against her, which were ignored. ${ }^{355}$

According to the Tripartitum, four basic privileges were afforded to the nobility. The privilege most frequently cited as evidence for conspiracy against the Countess, stated that nobles could not be arrested without a summons and notification of arrest from the Diet. ${ }^{356}$ While it was true that Bathory did not receive a summons or a notification prior to her arrest, there were some crimes named in this privilege which did not require a summons, including murder. ${ }^{357}$

Privileges like these existed across Europe, and because of them, Early Modern European judicial processes and courts were similar to a spider's web, able to catch small insects, but destroyed if a larger bug flew through it. ${ }^{358}$ The Early Modern judicial process was able to capture the smaller or socially inferior criminals, while at the same time having no power against the larger ones who were capable of causing significantly more damage. This was not an inaccurate comparison, as shown by the privileges above. However, it was not the only reason that judicial systems were largely unsuccessful in

\footnotetext{
${ }^{354}$ Cartedge, The Will to Survive, 96; Thorne, Countess Dracula, 37.

355 Thorne, Countess Dracula, 37.

${ }^{356}$ Werboczy, Customary Law, 57.

357 Werboczy, Customary Law, 57.

${ }^{358}$ Dean, Crimes in Medieval Europe, 30.
} 
preventing crime and had to use extreme measures to achieve the successes they did have.

Early Modern Europeans not only experienced a shift in power, but also in how the legal system functioned. Laws were based on written codes rather than customary traditions, and by the sixteenth century litigation had shifted from accuser based arguments to inquisitorial arguments. ${ }^{359}$ Rather than the offended party bringing all the evidence before a judge, now the crime was reported and the investigation and gathering of information was taken over by jurists or inquisitors. ${ }^{360}$ These men questioned everyone involved, compiling accounts of not only the incident in question, but also snapshots of the character of the accused and the accuser. ${ }^{361}$ The social position of the two parties now became of even greater importance since it determined how seriously the witness accounts were taken.

This process was long and time consuming, expensive, and invasive. ${ }^{362}$ Inquisitors demanded to be paid for their travel expenses, and lodging, on top of their fees. ${ }^{363}$ And they may be required to do a considerable amount of travelling to question not only direct witnesses, but also neighbors, friends, relations, and business associates of both sides. Those questioned were not likely to appreciate being dragged into the legal process, which could embitter their testimony. ${ }^{364}$ The extended process meant the accused may escape. The frequency of this happening was reflected in the ability to

\footnotetext{
${ }^{359}$ Vallerani, Medieval Public Justice, 4; Stokes, Demons of Urban Reform, 79.

${ }^{360}$ Vallerani, Medieval Public Justice, 4-5.

${ }^{361}$ Vallerani, Medieval Public Justice, 79-80.

${ }^{362}$ Dean, Crime in Medieval Europe, 10.

${ }^{363}$ Ruff, Violence in Early Modern Europe, 83; Julius R. Ruff, "Popular Violence and its Prosecution in Seventeenth and Eighteenth century France," in Crimes, Law, and Popular Culture in Europe, 1500-1900 ed. Richard McMahon (Portland: William Publishing, 2008), 40.

${ }^{364}$ Ruff, "Popular Violence and its Prosecution", 40.
} 
continue a trial with the accused in absentia, which was allowed in Roman law and made the conviction rate on the continent higher.

In sum, the three main reasons why people actually avoided using the legal system in favor of private vengeance was that it was expensive, invasive, and did not guarantee justice. Because of these limitations, the judicial system was seen as only truly useful for the very wealthy, who could afford the process, or for very local problems in towns and cities, which already had royally supported headmen to act as judges. ${ }^{365}$ When the situation did not favor either of these options, the choice was to use private violence to seek vigilante style justice, or to simply get on with life as much as possible. ${ }^{366}$ However, as established in the previous chapter, Bathory's crimes were not caused by seeking personal vengeance. Some may have been triggered by misdeeds, but the penalty far outweighed the crime. This may explain why over three hundred people were willing to come forward to denounce her, even if they admitted they were only able to repeat rumors.

The limitations of the judicial process made it necessary to ensure that when a court handed down punishment, it was remembered. Limited manpower and inadequate record keeping meant that the first goal of punishment was to prevent recidivism, which meant incredibly harsh punishments. ${ }^{367}$ The use of public beatings, branding, and

\footnotetext{
${ }^{365}$ Ruff, Violence in Early Modern Europe, 74; Rady, Nobility, Land and Service, 41, 58.

${ }^{366}$ Ruff, "Popular Violence and its Prosecution," 40.

${ }^{367}$ Dean, Crimes in Medieval Europe, 18-19; Stokes, Demons of Urban Reform, 83; Rublock, Crimes of Women, 78.
} 
mutilation, were all intended to discourage not only future problems with the accused, but anyone in the crowd who was considering doing something similar. ${ }^{368}$

Branding and mutilation were particular favored for petty thieves, since they were then easily identified wherever they went and lost the chance to steal again. ${ }^{369}$ Humiliation was used for social crimes such as gossip, pre-marital sex (unless it was not the first time), and drunkenness. ${ }^{370}$ For more serious crimes, however, more drastic action was taken. Execution and exile were possibilities for rape, theft, and murder; and executions gathered a large crowd, giving the judge a chance to remind the spectators to obey the law, or they would end up in a similar situation. The crudest form of penitentiary, the tower, was next to unheard of until the mid-seventeenth century on the continent, and when it became an option, it was considered rather cruel - which given the standards of the day should say something. ${ }^{371}$ Towers were cold, dark, damp, infested with the full spectrum of vermin, and did very little to encourage penitence in its residents. ${ }^{372}$ The penitentiary was not the same as the dungeon. Dungeons were intended for short-term stays while the accused awaited conviction or torture. They were not intended to be used as the penalty. ${ }^{373}$

The limitations and problems with Early Modern justice systems reflected their ultimate purpose -- to keep social order and control. ${ }^{374}$ Social order for Early Modern Europe demanded the power of the nobles over the laity, the predominance of Christian

\footnotetext{
${ }^{368}$ Rublock, Crimes of Women, 44, 80; Dean, Crimes in Medieval Europe, 19; Stokes, Demon of Urban Reform, 83, 44.

${ }^{369}$ Rublock, Crimes of Women, 80.

${ }^{370}$ Rublock, Crimes of Women, 34, 75.

${ }^{371}$ Rublock, Crimes of Women, 75-76

372 Rublock, Crimes of Women, 76.

${ }^{373}$ Silverman, Tortured Subjects, 66.

${ }^{374}$ Ozment, The Burgermeister's Daughter, 2; McMahon, Crimes, Law and Popular Culture, 7; Stokes, Demons of Urban Reform, 2.
} 
morals, and extreme methods to maintain that control. The power of the nobles was particularly important in Hungary, where the proto-middle class could not participate in state politics and was, by comparison to sixteenth century Western Europe, weak.

The Tripartitum outlined three different styles of trials, the most important for the Countess and the trial of her accomplices was the Common Inquest. This was an inquisition judicial process lead by a royal bailiff or, when there was one, the palatine. ${ }^{375}$ According to the legal code, the purpose of the Common Inquest was “... a definite clarification through testimony of witnesses of doubts arising from the responses made by the litigants before a judge," 376 and was frequently used to gather evidence for a noble trial before summons were sent. ${ }^{377}$ The judges of a Common Inquest could be neighbors or abutters near the site of the complaint, unless the dispute regarded property, in which case it was held elsewhere. ${ }^{378}$ This was how Thurzo began his investigation of Bathory and the rumors of murder against her. The Enthusiasts used this as a sign of conspiracy because Thurzo was ordered to begin the investigation when there were only rumors to go on, and because Bathory was not informed that an inquest was started against her. However, as stated, the very purpose of the Common Inquest was to determine if a crime had been committed, and if there was enough evidence to require a full trial. In this regard, Thurzo did not violate any law and there was no evidence for conspiracy. In a Common Inquest, anyone could give evidence so long as they were old enough to have actually remembered the incident, willingly took the oath to be honest in

\footnotetext{
375 Werboczy, Customary, 281.

${ }^{376}$ Werboczy, Customary, 281.

${ }^{377}$ Fugedi, Elefanthy, 66.

${ }^{378}$ Werboczy, Customary, 281.
} 
their testimonies, and were at liberty to be able to give testimony. ${ }^{379}$ This last part was tricky when it came to peasants giving testimony against nobles. Strictly speaking this was illegal and embarrassing for the noble. However if both parties agreed that peasant testimony could be allowed, it was permitted, though not be given equal weight to noble testimony, "[f]or peasants and commoners can be lured from the path of truth by gifts or threats much more easily and quickly than nobles," it was believed. ${ }^{380}$ A sticking point for the Enthusiasts, particularly Craft and Thorne, was that peasant testimony was allowed into the inquest. Both writers claim that this invalidated the investigation because a noble could not be charged on the word of a peasant. ${ }^{381}$ However, as stated above, the Common Inquest was not a trial and there were allowances for peasant testimony.

During a Common Inquest, each witness had to swear an oath that his or her testimony would be objective, truthful, and not for material rewards. ${ }^{382}$ If a noble was summoned and failed to appear to testify, he or she was fined approximately sixty-four florins; what happened to a peasant who failed to appear for summons was not mentioned. ${ }^{383}$ After the oath, the witness's name was written down, as was his or her relation to the defendant or the plaintiff. The testimony of noble neighbors carried more weight than nobles who merely lived in the same county. Writing down the basic information for witnesses also meant that attorneys for either side could refuse to allow witnesses or their testimony because of age, infamy, or the possibility of perjury. ${ }^{384}$ During testimony, the witness stated clearly if he or she was an eye witness, or if he or

\footnotetext{
${ }^{379}$ Werboczy, Customary, 281.

${ }^{380}$ Werboczy, Customary, 283.

${ }^{381}$ Thorne, Countess Dracula, 171; Craft, Infamous Lady, 159.

382 Werboczy, Customary, 283.

${ }^{383}$ Werboczy, Customary, 283.

${ }^{384}$ Werboczy, Customary, 283.
} 
she was merely repeating rumors or hearsay. Hearsay was not actually supposed to be considered evidence, but the Tripartitum allowed it if the witness was clear he or she was repeating rumors. ${ }^{385}$ Although its reputation has changed little between today and the Early Modern Era, gossip was considered a potential source of information for judicial procedures none the less. ${ }^{386}$

A bigger concern for the Common Inquest was perjury and those who gave false evidence. The punishments for perjury were stiff, and carried moral punishments as well. A witness who perjured him or herself forfeited all property rights, could not take action in court, and was removed from society. The Tripartitum stated:

Not only will he be disposed from [his property and land ownership], but in his own person he will lose his honor as a member of human society, and suffer such disgrace that he will be obliged to move among other Christians in distinct clothing at all times, with a belt of hemp, barefooted and bareheaded, as if he were relegated and separated from human society. ${ }^{387}$

However, someone accused of perjury or faith-breaking could regain his or her honor and social standing by paying two hundred florins. ${ }^{388}$ Being caught in perjury was not something many would risk; however, it happened often enough that the Tripartitum dedicated specific punishments and time to it.

The use of torture was the most retrospectively questioned method for gathering evidence within the judicial system of Early Modern Europe. In particular, the torture used against witches and other heretics took center stage as evidence for the barbaric and uncultured methods of the Early Modern judicial system. Without a doubt, the witch hunts and religious persecution were a horrible blight, but they were not at all a reflection

\footnotetext{
${ }^{385}$ Werboczy, Customary, 283.

${ }^{386}$ Rublock, Crimes of Women, 16, 20; Dicaprio and Wiesner, Lives and Voices, 184.

${ }^{387}$ Werboczy, Customary, 287.

${ }^{388}$ Werboczy, Customary, 287.
} 
of the normal process of judicial torture. Although there were some very creative uses of torture against witches and heretics, the judicial use of torture had very specific rules, much like public violence, which were ignored only in the most extreme circumstances -like when it was believed the Devil was on the verge of possessing an entire village through witches.

Torture for inquisitional cases was so prevalent and accepted that its use was frequently not even recorded. Therefore the full methods and situations which included torture will likely never be known to any real satisfaction. ${ }^{389}$ Torture, as a way to gain evidence, grew with the expanded use of inquisitional trials and its standard judicial use received little to no criticism from contemporaries. ${ }^{390}$ The very few times torture was criticized, critics merely questioned the level of truth acquired from torture, but they did not condemn or question the actual use. ${ }^{391}$ Again, it must be emphasized that the torture procedures and concepts for a judicial trial were not the same as the ones used for witchcraft and most heretic trials. Those cases received a sizeable amount of criticism from Humanist writers like Erasamus for the extreme use of torture.

The point of torture was to get to the truth. The Early Modern mind believed the truth was not given voluntarily, but had to be pulled from the body in a burst of spontaneity. The belief centered on the idea that man was naturally inclined to sin and lie, and was physically and morally incapable of telling the truth unless the body was in pain. ${ }^{392}$ Without the use of torture, the truth could not be confirmed. During a session the defendant was asked questions regarding the case and their answers were written down.

\footnotetext{
${ }^{389}$ Rublock, Crimes of Women, 2-3; Dean, Crime in Medieval Europe, 16.

${ }^{390}$ Silverman, Tortured Subjects, 3.

${ }^{391}$ Silverman, Tortured Subjects, 3.

${ }^{392}$ Silverman, Tortured Subjects, 9.
} 
The judge never applied the torture device or mechanism. He was trained to not only listen to the words which were said but also the tone in which they were said and the body language of the tortured. ${ }^{393}$ All of this was noted for either the confession, or to mark questions which required deeper probing. Although everything the defendant said was taken down, it was not considered a confession until after he or she was given several hours' reprieve. At that point, the confession was read back to him or her and the defendant was given a chance to confirm or recant their words. ${ }^{394}$ Recanting the confession usually meant more sessions, since the truth had to be discovered. Refusing to speak or continuing to deny the charges also marked someone for more sessions. If the defendant refused to confess after three sessions, he or she was released and declared innocent. ${ }^{395}$ Torture's status as an open secret in society meant that being a victim of torture carried no apparent social stigma. ${ }^{396}$

In general, a session of torture was to last no longer than thirty minutes, and the defendant was given about a day to rest and think about his crimes before the next session if there was no forthcoming confession. ${ }^{397}$ Torture was not supposed to kill or permanently maim since torture was not considered a punishment. ${ }^{398}$ A torture victim, regardless of guilt or innocence, may be injured but the injuries were ones which could heal. Having a convicted criminal appear whole and healthy made for a more effective execution; it would not do for the crowd to see a limp and broken man or woman for whom death was obviously a release from the pain of a twisted body. And if the victim

\footnotetext{
${ }^{393}$ Silverman, Tortured Subjects, 60.

${ }^{394}$ Dean, Crime in Medieval Europe, 15.

395 Rublock, Crimes of Women, 54.

${ }^{396}$ Silverman, Tortured Subjects, 66.

397 John Tedeschi, "Inquisitional Law and the Witch" in Early Modern European Witchcraft: Centers and Peripheries ed. Bengt Ankarloo and Gustav Henningsen (Oxford: Clarendon Press, 1990), 102.

${ }^{398}$ Silverman, Tortured Subjects, 66.
} 
was found innocent, there was no advantage in leaving him or her crippled. This did not mean that maiming and death did not happen, but good torture masters were the ones who caused the maximum amount of pain with minimal physical damage, relatively speaking. ${ }^{399}$

Few places have been more horrific to the modern mind than the torture chamber, a rational fear on which Hollywood has capitalized. Dark and humid, with the suffocating stench of vermin, sweat, and excrement paired with the stomach churning sounds of cracking bones and the blood curdling screams of agony has become the, not wholly inaccurate, popular notion of a torture chamber. But the goal of both the torture master and the judge was to get a confession or testimony as quickly and with as little effort as possible. ${ }^{400}$ This meant that torture was done in stages, each one escalating in pain and effort. The first level of a torture session was a tour and demonstration of the implements. In some cases, this was enough to get an accused person talking, without actually causing physical harm. This was still considered a torture session, however. The second session was more intense, with the use of implements such as thumb screws or boots which were designed to hurt the extremities, but leave the vital organs and head unharmed. This session may also have included forcing a victim to drink gallons of water, applying hot pokers to feet, and other such methods. If this was unsuccessful, the third stage included horrible implements such as the rack, the Judas Cradle or Chair, the choke pear, or boiling. The third session usually held the greatest risk of death because these methods

\footnotetext{
${ }^{399}$ Dean, Crime in Medieval Europe, 15.

${ }^{400}$ Dean, Crime in Medieval Europe, 16.
} 
attacked vital organs or introduced infection. ${ }^{401}$ It was little wonder that after three sessions without a confession victims were usually let go.

But implements were not the only item in a torture master's arsenal.

Psychological torture was also an option. Methods here included isolation, starvation, sleep deprivation, and even watching someone else be tortured. ${ }^{402}$ Pharmacological torture was infrequently used as well. Victims were given hallucinogens like nightshade and were questioned or observed under the effect of the plant. ${ }^{403}$ Likely the basis for the use of pharmacological torture was to let the victim's own guilt cause him or her to confess. How often psychological or pharmacological torture was used as compared to the use to torture implements was never really recorded. Both were simply considered torture.

Dr. Szadeczky-Kardoss, Craft, and Thorne argued that the use of torture against the Countess' four accomplices after their arrest negated their confession because people would, and did, say anything under torture. ${ }^{404}$ This anachronistic argument has failed to consider the historical context of torture and its use in the judicial system. Part of the reason that the torture of the accomplices was treated as suspect was because it was not recorded in the official transcript of the trial which was sent to King Matthias. ${ }^{405}$ Thorne in particular argued that the omission indicated that torture was known as an inaccurate method of gathering evidence and that its use was purposely removed so there were no

\footnotetext{
${ }^{401}$ Dean, Crime in Medieval Europe, 16.

${ }^{402}$ Stokes, Demons of Urban Reform, 5.

${ }^{403}$ Stokes, Demons of Urban Reform, 5.

${ }^{404}$ Thorne, Countess Dracula, 39; Craft, Infamous Lady, 138.

405 Thorne, Countess Dracula, 39; Craft, Infamous Lady, 140.
} 
questions of the authenticity of the confessions. ${ }^{406}$ While this cannot be fully refuted as a possibility, it was still unlikely. First of all, torture was largely expected in an inquisitional trial, the type the accomplices faced. For Palatine Thurzo to have expected to "pull the wool" over Matthias' eyes regarding such an openly accepted judicial method insulted the intelligence of both men. Secondly, the decision to note the use of torture was the choice of the individual scribe who compiled the transcript. ${ }^{407}$ It may simply have been left off as a matter of personal preference and not as any kind of conspiracy. Finally, the idea that torture was an inaccurate method of achieving testimony, as already discussed, was not debated until several decades after the trial. Even then, the context in which torture was questioned was regarding witch trials, not judicial trials, and was a subject that was more heavily discussed in Western Europe than in Hungary.

On the matter of torture, the Tripartitum is oddly silent. There was no mention of its use specifically, but one of the conditions for a proper Common Inquest was that witnesses were able to speak at liberty. This meant that he or she had to be able to speak without fear of violent coercion. Testimony was instead supposed to be given “...merely at lawful bidding." 408 This passage indicates that a witness was not to be tortured; however it did not exclude the plaintiff or the defendant having experienced torture. Even at that, the phrase "lawful bidding" is vague and unclear. Judicial torture was recognized as a lawful and permitted method of gathering evidence, so does this indicate that torture was allowed against witnesses? On this subject, the Tripartitum did not give any insight. It did not strictly forbid the use of torture but it did not promote it either. It must therefore

\footnotetext{
406 Thorne, Countess Dracula, 45.

${ }^{407}$ Rublock, Crimes of Women, 2-3; Dean, Crime in Medieval Europe, 16.

${ }^{408}$ Werboczy, Customary, 281.
} 
be accepted that torture was in Hungary, like the rest of Europe, regarded as a legitimate means of gathering information from accused criminals.

It will never be conclusively proven that the use of torture was not left off the trial documents as a conspiracy against the Countess, but the historical and social context makes this a rather remote possibility. To disregard the testimony presented in an Early Modern European trial as a sham or show trial because of the inclusion of torture means that all Early Modern European trials have to be regarded as such. Thorne, in his analysis of the trial documents, has given additional reasons to question the testimony given by the four accomplices, which will be discussed later. Ultimately, the use of torture can not be truly considered among the reasons to question the legality of the trial of Bathory's accomplices. 
CHAPTER VI

AWKWARD BEDFELLOWS:

THE COUNTESS AND

EARLY MODERN

HUNGARIAN

JUSTICE

The general populace of enthusiasts and biographers of Bathory, debated two issues particularly hotly: why she turned to murder and whether she was actually guilty. With no Bathory family archive, the primary sources needed to answer either question has not been found. Therefore, this exploration of the historical context, based on scholarly research, has isolated the most realistic answers - with significantly different results. Works on Bathory have changed and evolved with new information. Valentine Penrose, and those before her, implicitly accepted Bathory's guilt and the madness and self-obsession which drove her to commit the crimes. ${ }^{409}$ Since Penrose was the first English language source on Bathory available in the Western world, it was not surprising that her conclusions remained more well known and for most people, represented the end of any debate: Bathory was selfish and insane; she killed girls out of jealousy; and she

\footnotetext{
${ }^{409}$ Penrose, Bloody Countess, 14.
} 
became a symbol of all that was awful and wrong about nobility. Raymond McNally, too, largely accepted her guilt and madness, though he did leave open the possibility of innocence after his article with Rodu Florescu on vampirism in the Slavic world. ${ }^{410}$ While the tone of McNally's book supported her guilt, the earlier article with Florescu was far more sympathetic to the possibility of her innocence.

Irma Szadeczky-Kardoss wrote a dissertation and two articles on the subject of Bathory's guilt or innocence from the perspective of a trial lawyer defending the Countess. When asked by Thorne during his research if she could create a case for the prosecution, she told him she could not. ${ }^{411}$ It was from her, disseminated through Throne since her own work was never translated to English, that the argument of a sham or show trial emerged, an idea that enthusiasts eagerly latched onto with a vice-like grip. ${ }^{412}$ Sham and show trials were of particular interest at the time of Szadeczky-Kardoss's work in 1993 as Communism crumbled across the Eastern bloc and the details of such trials came to light. Tony Thorne's own work kept to the middle ground regarding her guilt or innocence; however, his support of a conspiracy based on her gender indicated that he was more willing to accept her innocence. ${ }^{413}$ Kimberly Craft - a legal researcher who was the first English-language author to reject her madness openly - like Thorne, supported the idea of a conspiracy, but unlike him, strongly favored her guilt. She presented several possibilities for why Bathory turned to murder, the most detailed of

\footnotetext{
${ }^{410}$ Raymond McNally and Rodu Florescu, "Vampirism: Old World Folklore," in The Vampire in Slavic Culture, Revised Edition ed. Thomas J. Garza (San Diego: Cognella, 2012,) 50.

${ }^{411}$ Thorne, Countess Dracula, 188.

${ }^{412}$ Thorne, Countess Dracula, 188.

${ }^{413}$ Thorne, Countess Dracula, 141.
} 
which was an undiagnosed anxiety disorder caused her to lash out at servants. ${ }^{414}$ The evolution of works about Bathory began heavily in favor of her guilt, moved to proclaiming her innocent, and returned to her guilt, but with mitigating factors.

But what evidence from her case supported her guilt, what factors led scholars and legal authorities to support her innocence, and what does her case reveal about womanhood, nobility, and Early Modern justice? The evidence to support her guilt, such as the family agreement and witness testimony, outweighs most support for her innocence, but both must be considered. Regarding her guilt, the impressive efforts of both her family and Palatine Thurzo, prompted by the family agreement, suggested strongly that there was suspicion of her guilt among those closest to her. ${ }^{415}$ The Countess also changed the explanation for the deaths regarding the girls of lesser nobility in her care, and there was no noble outburst over her house arrest. Those who support her innocence rely on the lack of confirmed victims and the use of rumor and hearsay evidence used in her investigation. Most physical evidence that modern courts rely on -bodies, weapons, and assorted forensics -- cannot be included when considering the evidence against Bathory for two main reasons. First, and most obvious, is the span of time: over 400 years, evidence of torture that was focused on soft tissue, such as bludgeoning, has eroded with the natural process of decay. ${ }^{416}$ Secondly, no bodies were dug up and directly connected to her. ${ }^{417}$ There is no cemetery or memorial for the victims of Bathory. Hence even if bodies were found, there would be almost no way to tell if they

\footnotetext{
${ }^{414}$ Craft, Infamous Lady, 12.

${ }^{415}$ The family agreement, arranged between Thurzo, Paul Nadasdy, and the Countess' sons in law, allowed Thurzo to arrest the Countess without argument from the family so long as he was able to keep her from going to trial.

${ }^{416}$ Paul Barber, "Forensic Pathology and the European Vampire," in The Vampire: A Casebook ed. Alan Dundes (Madison: University of Wisconsin Press, 1998), 116.

${ }^{417}$ Craft, Infamous Lady, 118.
} 
were victims of the Countess, or simply one of the unfortunate statistics that made Early Modern Hungary so violent.

With forensic evidence unavailable, the burden of proof for guilt rested on the private agreement between the family and Palatine Thurzo, and the actions of her accusers. Early modern justice was not known for being adept at catching and prosecuting nobles who either knew the legal system well enough to take advantage of loopholes, or were wealthy enough to pay for a loophole to emerge. The fact that Bathory was not allowed to go to trial is perhaps the greatest indication of her guilt. Thurzo's agreement with the family prevented any trial, suggesting there was enough evidence to worry about her being found guilty and ruining the family's reputation. Her lack of trial was interpreted by Craft, Thorne, and McNally, in particular, as indicative of a conspiracy against her by the king and palatine who desired her land and feared her power because she was a single woman who controlled her own resources. ${ }^{418}$

Such a fear was unusual in Eastern Europe, where the virago was a respected part of the community, and unheard of for noble women who were expected to be in control and in charge of their estates. The Tripartitum's language regarding noble rights did not exclude women specifically, and letters from Bathory to tradesmen indicated that for much of her marriage she was the one handling the bills while her husband was at war. ${ }^{419}$ Bathory was a widow for five years before her arrest, and during that time she followed the traditional, legal, and cultural lifestyle of a noble widow. If the basis of the case against her was concern about her single status, it was more easily solved by following

\footnotetext{
418 Thorne, Countess Dracula, 141; Craft, Infamous Lady, 118; Penrose, Bloody Countess, 168; McNally, Dracula was a Woman, 72.

${ }^{419}$ Craft, Private Letters, 18.
} 
the French and English model of ordering another marriage or by applying pressure to her male relations to arrange a second marriage for her. Arresting her and charging her with murder on the basis of fear of a wealthy widow, while a "tidy" story, does not make sense after considering the duties and responsibilities of a noblewoman and the perception of powerful women in Eastern Europe.

The argument supported by Craft and Thorne, that the king wanted land, and that Thurzo hoped to gain some of the Bathory land, was as full of historical "holes" as fear of a wealthy widow. ${ }^{420}$ At the time of her arrest, Bathory did not own the lands and estates she had throughout her marriage. At her husband's death, she retired to her dower, the Castle Cjesthe, and her son inherited the rest. Since Paul was not of legal age at the time, his tutor was made his legal guardian. Therefore, if Thurzo and Matthias were hoping to gain the Nadasdy lands, it was much more effective to go after the son and not the mother. Additionally, the Hapsburg family had more land than they could control or give away. ${ }^{421}$ For Matthias, the land was nothing but a nuisance, a fact supported by the Royal Treasury. ${ }^{422}$ Thurzo would not gain anything from the land either. The Tripartitum was very clear that he could not benefit materially from prosecuting Bathory, and he seemed intent on respecting that since he chastised the Countess' own daughter for taking a bracelet from her mother's things. ${ }^{423}$ Finally, the charge of treason would have been a far more successful and unquestioned method of getting land from the Bathory-Nadasdy clan than a charge of murder. Despite this, Matthias repeatedly insisted on the charge of murder even though Thurzo continued to prevent a trial from taking place.

\footnotetext{
${ }^{420}$ Craft, Infamous Lady, 118; Thorne, Countess Dracula, 12.

${ }^{421}$ DeWold, The European Nobility, 27.

${ }^{422}$ Craft, Infamous Lady, 253-254; Thorne, Countess Dracula, 195-196.

${ }^{423}$ Werboczy, Customary Law, 275; Thorne, Countess Dracula, 210.
} 
The main reason Bathory was not brought to trial was because of the private arrangement with Paul Nadasdy, his brothers-in-law, and Thurzo. The agreement essentially boiled down to Thurzo arresting and confining the Countess without opposition from the family as long as he did everything he could to prevent a trial. ${ }^{424}$ This agreement indicated that the family knew or believed that the Countess was involved in some kind of crime that would result in the family losing their social, political, and economic status. According to the Tripartitum, the crimes that resulted in the loss of noble privilege were treason, rape, theft, and murder. ${ }^{425}$ The law was not clear however, if the family suffered or if the penalty fell squarely on Bathory. This was a possible secondary purpose of the agreement, to use as proof that the family was not involved and had tried to stop her.

In the case of all four crimes the family needed to ensure that Bathory did not escape and was not caught by anyone else. According to noble rights and privileges, if she was accused of any of those crimes she did not have to receive a royal summons and she could be apprehended by anyone, including a peasant, unless she escaped the country, in which case she could not be charged. ${ }^{426}$ Evidence that she was a flight risk, however, was minor and linked only to the fact that she was aunt of the king of Poland, Gabor Bathory. Thorne uncovered a letter indicating Bathory was considering leaving Hungary for Poland because she inquired about receiving papers for travel. Gabor, in his response, seemed more than happy to accommodate his relation, but no further steps were taken. ${ }^{427}$ Thorne interpreted this as indicative that Bathory knew she was in trouble and was

\footnotetext{
${ }^{424}$ Thorne, Countess Dracula, 160.

${ }^{425}$ Werboczy, Customary Law, 57.

${ }^{426}$ Werboczy, Customary Law, 57.

${ }^{427}$ Thorne, Countess Dracula, 158; Penrose, Bloody Countess, 167.
} 
planning an escape. ${ }^{428}$ However, months after the letter, the Countess was still in the country, with no further evidence that she was considering leaving.

Why the family did not help her escape, especially if the family honor and position was at stake, is not clear. Speculation, taking into consideration the historical context as well as the patterns of Bathory's behavior allowed for two realistic possibilities: the members of the family were worried that aiding her flight marked them for treason, or the family had no idea she even wanted to leave. After her angry response to Francis going to Transylvania, leaving was uncharacteristic. Since the only written proof she was considering leaving was the letter to her relation in Poland, the family may have had no idea the thought had crossed her mind. The family risked punishment for helping a fugitive if she did attempt to leave and was caught. While the question of why the family did not help her leave will never be answered, since the needed documents and evidence are yet to be uncovered, fear of treason and lack of awareness of a desire to leave were the most plausible reasons.

The private agreement to confine the Countess, without argument or reprisals from the family against the state, changed from its first conception until the Countess was finally arrested. Originally she was to be taken to a convent where she would live out the rest of her days. ${ }^{429}$ This was an unusual choice considering she was Calvinist, but one that was both traditional and may have been planned to appease the very Catholic Matthias to keep him from asking more questions. Ultimately the plan was changed to confining her to a room in her own castle for reasons left to speculation because of lack

\footnotetext{
428 Thorne, Countess Dracula, 158.

${ }^{429}$ Craft, Infamous Lady, 117; McNally, Dracula Was a Woman, 61; Penrose, Bloody Countess, 161; Thorne, Countess Dracula, 160.
} 
of hard evidence. Most likely Paul did not believe that his mother would tolerate being in a convent due to her religious beliefs, or he worried that doing so would indicate his involvement in the plan and limit what she left him in her final will. Either way, the goal was to purposely keep her from trial so she was not found guilty and did not risk the family's place and power. The agreement does represent a conspiracy, but one that was intended to protect her and the family, not one actively against her.

The rest of the evidence to support her guilt surrounded her own actions regarding the explanations of the deaths and the disposal of the bodies. The Countess changed her story about the large number of deaths after starting a finishing school for lesser noble daughters. Previously, when questioned about the cause of death for servants, she claimed it was the result of disease. ${ }^{430}$ For some time this was accepted, but the local church soon refused to bury the dead unless it was able to see the bodies. Bathory declined, and so was forced to hold burials in secret. ${ }^{431}$ After her husband's death, she did not even seem to bother with anything resembling a funeral for her victims, but instead just ordered the bodies disposed of quickly and quietly. ${ }^{432}$ Craft argued that towards the end, servants got very sloppy and bodies were found in grain stores, by roadsides, and once a dog dug up a body while she was visiting her daughter and paraded through the courtyard with a hand in its mouth. ${ }^{433}$ However, when it came to the gynaeceum deaths, she changed her story. Rather than claiming the deaths were the result of disease, she claimed that after being caught stealing, one of the students killed the other girls before

\footnotetext{
${ }^{430}$ Craft, Infamous Lady, 55; Penrose, Bloody Countess, 160; Thorne, Countess Dracula, 152.

${ }^{431}$ Craft, Infamous Lady, 102.

${ }^{432}$ Craft, Infamous Lady, 109-110.

${ }^{433}$ Craft, Infamous Lady, 110.
} 
killing herself. ${ }^{434}$ Had this been true, surely Bathory would have felt no reluctance about releasing the bodies back to the families or perhaps refunding the tuition that was paid. The Countess did neither. ${ }^{435}$

In fact, fewer questions may have been raised if she had stayed with the story of disease. With so many people interacting in a confined space with the low standards of hygiene in the sixteenth century, it would have hardly raised a brow. Even a century later, in the cleanest and finest run boarding schools in Europe, death by disease was an understood and accepted risk. ${ }^{436}$ Had she argued disease again, refusing to release the bodies would have been unquestioned as a health and safety precaution, especially in epidemic plagued Hungary. Why Bathory felt she needed to deviate from her story, and still not release the bodies of the girls with whom she was entrusted with, raised more questions than it answered, especially since it was the death of these girls that truly put the Countess at risk for punishment. Serfs and servants were one thing; they were considered a resource and could be treated as the Countess saw fit. The students from her school, however, were lesser nobility and entitled to the same privileges she enjoyed. Her actions with the deaths of the noble daughters suggested she had something specific to hide.

Thurzo's arrest report claimed he found recently dead victims when he entered Castle Cjesthe, though how many he actually found varies in number from two dead girls and one nearly dead girl, as Craft described, to eighty girls, as Kerry SeGrove and others

\footnotetext{
${ }^{434}$ Craft, Infamous Lady, 113.

${ }^{435}$ Craft, Infamous Lady, 108.

${ }^{436}$ Carolyn C. Longu, "Its Frequent Visitor: Death at Boarding School in Early Modern Europe," in Women's Education in Early Modern Europe: A History 1500-1800 ed. Barbara J. Whitehead (New York: Garland Publishing, 1999), 205.
} 
claimed. ${ }^{437}$ Regardless of the actual number, the result was the same: Thurzo claimed to catch Bathory red-handed in the act and therefore saw no need to waste time with a formal trial for what he himself had seen. However, neither Paster Ponikenusz, nor Meygeri, Paul's tutor, who were part of the Cjesthe raid party, reported anything similar. Then again, it was unclear if they needed to file the same kinds of reports that Thurzo did to the king. Regardless, as Thorne correctly pointed out, the claim that Bathory was caught red-handed was Thurzo's and no evidence has yet emerged which validates or discredits the palatine's report. ${ }^{438}$ Thorne promoted Szadeczky-Kardoss's argument that even if Thurzo had caught her in the act, his small group of soldiers, the priest, and the tutor were not enough to validate Thurzo's arrest of her on the spot. According to Thorne and Szadeczky-Kardoss, at least seven nobles needed to witness this to make the accusation legally stick. ${ }^{439}$ The Tripartitum said nothing about this; in fact it was an assertion of custom, not a law. And for a charge of murder, the Tripartitum stated, "if possible, [the alleged murderer] may be freely arrested even by the hand of a peasant at the place where the crime and wrong was committed, and condemned according to his misdeeds and punished according to his desserts." ${ }^{, 40}$ It may not have mattered to Thurzo if he had the proper number of people to make the claim he did, since he was already assured of the family's support in the arrest of the Countess, so long as he kept her away from a trial. With this support, along with the already established fact that he gained nothing from her downfall, there was little reason to believe he artificially inflated the

\footnotetext{
${ }^{437}$ Craft, Infamous Lady, 133; Penrose, Bloody Countess, 166; SeGrove, Women Serial and Mass Murderers, 22.

438 Thorne, Countess Dracula, 186.

439 Thorne, Countess Dracula, 186.

${ }^{440}$ Werboczy, Customary Law, 57.
} 
evidence to arrest the Countess. The family supported the decision; all Thurzo needed was enough evidence to support his own actions before the king without revealing the agreement with the family.

Hungarian nobles were protective of their legal rights and privileges, and often took a threat against one as a threat against all. Therefore it was very surprising that there was no noble outrage when the news came out that the Countess was under house arrest, without, if the Enthusiasts were correct, the proper due process. As Thorne, Craft, and McNally all pointed out, Thurzo timed his entrance into Cjesthe purposefully, so that the Diet was out and there was not enough time for the Diet to ask questions or insist Bathory be brought to trial. ${ }^{441}$ Even so, after the news of the Countess's confinement was revealed, there was almost no demand of trial or outpouring of noble rage. Craft argued that several nobles demanded Bathory be brought to trial, but what evidence she had to support that was not clearly stated in her book. ${ }^{442}$ Thorne and McNally both counter Craft's assertion of noble outrage by pointing out that it was Matthias who was pushing for a trial, not the Diet. ${ }^{443}$ In fact, there seemed to be very little surprise or outrage that the Countess was confined without a trial, suggesting her tortures and crimes were an open secret. Otherwise, the other nobles would have followed historical precedent and stood up to defend their own.

In the end, the only one who repeatedly demanded a trial was Matthias himself, and he may only have done it for political reasons. Thorne took particular note of the timing of Matthias's demands for trials; each demand coincided with a potential threat

\footnotetext{
${ }^{441}$ Craft, Infamous Lady, 134; McNally, Dracula was a Woman, 72; Thorne, Countess Dracula, 173.

${ }^{442}$ Craft, Infamous Lady, 167.

${ }^{443}$ Thorne, Countess Dracula, 172; McNally, Dracula was a Woman, 82.
} 
from Bathory's nephew, King Gabor. ${ }^{444}$ Matthias's demand for a trial can be seen from three angles. First, he wanted to continue to assure the Hungarian nobles that he understood and supported the rights and privileges he had sworn to uphold at his coronation. Secondly, he wanted to assure Gabor that Bathory was not being held illegally. Finally, he wanted to assert that he was the one ruling Hungary, not Thurzo.

The claims made by McNally, Thorne, and Craft that Matthias wanted Bathory on trial to negate a debt to her was a false The original debt was to Francis, but when he died, his wife took up the crusade to get the money back, and upon her death the charge fell to her son or her sons-in-law. ${ }^{45}$ Without removing the entire family from power, Matthias' debt to them was not cancelled. The best way to do so was to charge the family with treason, which could have been easily trumped up; instead, Matthias continued to insist that the charge against Bathory be murder, not treason.

Despite the heavy supportive evidence of guilt, true crime, gothic lifestyle, and Hungarian blogs continue to support Bathory's innocence. Much of the evidence used by these supporters, however, has not been properly placed within Early Modern Hungary's legal and political context and instead transplanted modern judicial processes, which only invalidated their arguments. The first support for her innocence was that no specific bodies were presented as evidence. That does not mean no physical evidence was found. Aside from the bodies reportedly found by Thurzo, Pastor Ponikenusz reported finding nine female bodies, who had suffered horrendous torture, dumped unceremoniously in the catacombs between the castle and the chapel. ${ }^{446}$ This was recorded in a letter that was

\footnotetext{
${ }^{444}$ Thorne, Countess Dracula, 176.

${ }^{445}$ Werboczy, Customary Law, 325.

${ }^{446}$ Craft, Infamous Lady, 116.
} 
delivered to Matthias, and if true would be a coffin nail in the reasons to support the Countess' guilt. However, beyond writing and sending the letter, no further action was taken. There was no record that Thurzo or any other official confirmed the presence of the bodies there. Additionally, although all the accomplices were able to give locations for other bodies, and the testimonies of others were able to give even more, no bodies were dug up with the specific intent of verifying their testimony. ${ }^{447}$ This lack of identified physical evidence has left amateur historians and bloggers questioning if she was ever guilty of murder; however, none of the Enthusiasts have taken up this banner.

Instead, the Enthusiasts supported the second major reason she might have been innocent: aside from the testimony of her accomplices, nearly all the witnesses at the trial merely repeated hearsay and rumor. ${ }^{448}$ According to the strictest rules set out by the Tripartitum, this was not allowed. Witnesses at a Common Inquest were supposed to relate eye witness accounts only. ${ }^{449}$ The fact that Thurzo allowed witnesses to testify with such scant information was treated by the Enthusiasts as evidence of a conspiracy against the Countess to deprive her of her right to justice and of the fact that the charges were trumped up or outright false. This ignores two facts. First of all, Thurzo did not actually intend to gather evidence against the Countess since he had no intention of letting her go to trial. There was, therefore, no need for evidence against her. And while hearsay evidence was not usually allowed in cases against nobility, there was no prohibition against its use on non-nobles, such as Bathory's accomplices, and non-noble testimony

\footnotetext{
${ }^{447}$ Craft, Infamous Lady, 110-111.

${ }^{448}$ Craft, Infamous Lady, 121; Throne, Countess Dracula, 271; McNally, Dracula was a Woman, 72.

${ }^{449}$ Werboczy, Customary Laws, 283.
} 
could be admitted as evidence if both parties allowed it to be entered. ${ }^{450}$ While the Common Inquest was used to gather evidence for noble trials, the private family agreement allowed for acceptable legal fudging that meant Thurzo did not have to follow the strict rules laid down for nobles.

Additionally, while it was always possible that witnesses lied on the stand, it was very unlikely. Perjury carried very real legal and spiritual consequences. Testimony may have been based on hearsay or rumor, but witnesses at Bathory's investigation were clear that what they presented was, in fact, rumor. ${ }^{451}$ A report sent to Matthias on July 28, 1611 recorded the answer of 224 witnesses to the question of

...whether the magnanimous and noble Lady Erzsebet Bathory....as with animal savagery directed and driven by devilish sense, cruelly killed numerous innocent virgins, nobles as well as lower-class maids alike without the slightest blame upon them, their bodies mutilated and burned with hot iron pieces of flesh torn from them, roasted in the fire and given to them to eat... ${ }^{452}$

Because of the large number of witnesses, the testimonies in this report were often lumped together by city, unless the witness was a noble, a clergy man, or a judge, in which cases testimony was recorded alone. Additionally, many of the testimonies were not recorded verbatim, but referenced previous testimony. By far the most referenced testimony was that of Nicolous Mednyansky, who was the $99^{\text {th }}$ witness and a notary. His testimony was not quoted, but recorded in general that, "he had no knowledge of and could say nothing regarding the questions posed, but he had heard from everyone what the Lady Widow had done." ${ }^{453}$ A total of sixty-one other witnesses were specifically noted as giving the same testimony. Of the remaining 162 witnesses, a total of ninety-

\footnotetext{
${ }^{450}$ Werboczy, Customary Law, 283.

${ }^{451}$ Craft, Infamous Lady, 121.

${ }^{452}$ Craft, Infamous Lady, 255.

${ }^{453}$ Craft, Infamous Lady, 269.
} 
eight admitted that anything they reported was based on hearsay and rumor. That such a large number had heard of the tortures and atrocities was not surprising. The first witness, Pastor Michael Fabri, testified "...that he heard freely and, in general, far and wide of the alleged cruelty of said Mrs. Erzsebet Bathory; but whether all this is said regarding Lady Erzsebet Bathory is true is certainly not known to him." ${ }^{454}$ This was not a situation in which people on the stand were either trying to pass rumors off as fact, or make up their own rumors. There was no reason to assume that the testimony given at the Common Inquest was not truthfully related, even if the rumors themselves were false. ${ }^{455}$ More importantly, those witnesses unable to relate a specific event were not recorded verbatim, while witnesses who related specific instances of abuse related to the question were encouraged to go into detail. Therefore had Bathory been brought to trial, the evidence would have eye witness, detailed, and not rumor, so there was no violation of the Tripartitum.

A few additional points must be raised regarding the witnesses against the Countess. As Thorne, Craft, and McNally indicate, those who were called to the stand bore a grudge against the Countess, or had personal reasons to want to see her punished for something. ${ }^{456}$ Again, according to the Tripartitum, these people should not have been allowed to testify, since they were likely to lie or inflate their testimony ${ }^{457}$ While this may have been true, these witnesses were not actually questioned until Matthias ordered Thurzo to dig beyond the original thirty-six witnesses he had questioned before the arrest,

${ }^{454}$ Craft, Infamous Lady, 255-256.

455 The remaining 64 witnesses were those whose testimony was not entirely based on hearsay or rumor. Most of them testified to seeing abused maids, dead bodies, and being present at secret burials. The story most related was of an unnamed serving girl who went to a physician for a disfigured right hand and arm. Craft Infamous Lady, 255-283.

${ }^{456}$ Craft, Infamous Lady, 159; Thorne, Countess Dracula, 168.

${ }^{457}$ Werboczy, Customary Law, 283. 
and it was here that witnesses that were debtors or held a grudge against her were called. Again, however, this was when Thurzo was forced to gather more evidence that he had no intention of ever actually putting to use. While Craft and Thorne, who focused on this aspect in particular, are correct that the testimony should not have been used, the fact remained that it was never intended to be anyway. While merely speculation, Thurzo's deviation from the Tripartitum's clear rules may have been a specifically targeted attempt to negate any of the evidence he had; intentionally "shooting himself in the foot," legally, to further ensure that if he was unable to keep her from a trial, the actual decision would be bogged down with mistrial evidence. McNally, Thorne, and Craft are all accurate in their assessment that both the testimony and witnesses were problematic, but it must be understood that Thurzo was doing all of this knowing that as long as he lived, Bathory would never face trial. These inconsistencies in evidence gathering did not indicate innocence, but rather confirmed that Thurzo had no plans to try the Countess. The Enthusiasts' supposed evidence of innocence, the lack of physical evidence and the questionable testimony, were flawed and relied on a weak knowledge of the Tripartitum, and ignored the fact that Thurzo never intended the evidence to be used. This does not mean that Bathory was guilty, but rather that better, stronger, evidence for her innocence must be found and so far it has not.

Since Bathory never faced trial, the debate over her guilt or innocence distracted from the better question: was the evidence against her properly and legally gathered? And if it was not, does it represent a conspiracy or does it represent another dysfunction of the Early Modern judicial process? McNally, Thorne, and Craft all agree that the evidence was not properly gathered, based on a gender or political conspiracy against the 
Countess. ${ }^{458}$ Although he had a reputation for ruthlessness, Thurzo was a stickler for the rules in nearly every other regard. The gathering of the testimony, considering it was never intended to be used against a noble, was done by the strictest letter of the law. Each of the original thirty-six witnesses had their names, occupations, and connections to the Countess recorded, as was required. ${ }^{459}$ For the second, much larger, round of gathering, this procedure was not followed because of the sheer number of people being questioned. However, for the second round of questioning, Thurzo and the judges were not following the rules of a Common Inquest, but were following those of the Simple Inquest that did not call for the same sort of record keeping since it was designed to handle large numbers of common witnesses. ${ }^{460}$ In both cases, however, the testimonies were taken and given in Hungarian, not Latin. For the few witnesses who did not speak Hungarian, such as Ponikenusz, translators were provided so that the transcript was written solely in Hungarian. ${ }^{461}$

The selection of witnesses for the initial Common Inquest totaled thirty-six nonnobles and did not include anyone who spoke for the Countess's innocence. This followed the rules of witnesses as laid out by the Tripartitum; non-nobles could not speak to the defense of nobles. ${ }^{462}$ Of course, it would be socially humiliating for a noble to be imprisoned on the word of a servant, but in a Common Inquest testimony was gathered to judge if there was enough evidence to bother with a trial. ${ }^{463}$ Obviously this was needed if Thurzo failed to keep the Countess out of court. Instead, the original thirty-six formed the

\footnotetext{
${ }^{458}$ McNally, Dracula was a Woman, 60; Throne, Countess Dracula, 224; Craft, Infamous Lady, 137 -

${ }^{459}$ Werboczy, Customary Law, 281.

${ }^{460}$ Rady, Nobility, Land and Service, 71.

${ }^{461}$ Thorne, Countess Dracula, 39.

${ }^{462}$ Werboczy, Customary Law, 283.

${ }^{463}$ Rady, Nobility, Land, 72.
} 138. 
basis for the questions which were be laid out for the four accomplices. Had the Countess been brought to court nobles would have been brought forward to provide evidence in her support. Thorne argued that Bathory was preparing for questions about the deaths and was building her own defense, pointing to a document in which a mother signed a statement absolving Bathory of her daughter's death and reaffirming the old story that it was the result of disease. ${ }^{464}$ Thorne was particularly condemning about this because it was never used or brought up. The reason why was, of course, very simple; it was the word of a non-noble, and such testimony could not be used in support of a noble for the same reason it alone was not enough to convict a noble - non-nobles were easily coerced. $^{465}$

Thurzo kept his promise and Bathory never had a trial, although in the end, it was only because she died just as he was running out of excuses. So then why do enthusiasts and scholars like Szadeczky-Kardoss continue to believe and support the idea of a show trial if the Countess herself was never actually tried or charged? That came from the trial of the accomplices, who were subject to very different laws because they were servants. While Bathory herself was confined to her room after the New Years Eve raid, her four accomplices were arrested and immediately sent to trial. Craft, McNally, and Thorne argued there were in fact two trials for the accomplices, the first one privately held, and the second one held in public, which was little more than a rehashing of the statements already given by the accomplices and the announcement of their punishments. ${ }^{466}$ This was not a show trial. It was normal practice for the charges and evidence against the

\footnotetext{
464 Thorne, Countess Dracula, 152; Craft, Infamous Lady, 126.

${ }^{465}$ Werboczy, Customary Law, 283.

${ }^{466}$ Craft, Infamous Lady, 139; McNally, Dracula was a Woman, 78; Thorne, Countess Dracula, 167.
} 
accused to be read out publicly before the sentence was performed. ${ }^{467}$ The accusation of show trials was based on a lack of understanding regarding the Early Modern judicial system. The accomplices did not face anything resembling a modern trial system, so the two trial argument was anachronistic, the public announcement and execution was never intended to be a trial.

The trial of the accomplices did not deviate specifically from any laws or customary actions regarding Early Modern justice, including the use of torture to gain confessions. The transcript of the interrogations compiled by Thurzo stated that "...the confessions of the defendants...were given either voluntarily or after torture..." Clearly they were tortured, but how exactly was not made clear or described by the transcripts; it may have required little more than a tour and a demonstration of the implements.

After confessing, under torture or not, the punishments they received reflected not only their level of involvement with the crimes, but also their respective ages, with youth receiving a lighter sentence. Ilona Jo, Dorottya Szentes, and Janos Ficzko were executed; Katalin Beneczky was given life imprisonment but was later released to disappear into history. Of the three who were executed, Ilona and Dorottya were burned at the stake after having their fingers removed while Janos, because of his youth, was beheaded before his body was thrown onto the fire. Concerns from the Enthusiasts about show trials and illegality in reference to the accomplices stemmed from a lack of understanding about the place of torture within the Early Modern justice system, and the anachronistic grafting of modern ideas of judicial process onto the past.

\footnotetext{
${ }^{467}$ Weisser, Crime and Punishment, 24.

${ }^{468}$ Craft, Infamous Lady, 243
} 
Although the legality and customs of the accomplices' trials were within the norm, there were certain aspects that bear noting either because they were unique, or because of their effect on the Countess' reputation. What information we have on Bathory's crimes came from the confessions of the accomplices, the testimony of the other couple hundred witnesses, and the small number of letters found from or to the Countess. Thorne's book included a full chapter analyzing the trial of the accomplices but only the major points of interest will be highlighted here. ${ }^{469}$ As Thorne discussed, each accomplice was asked the same eleven questions, which mimicked in some ways the lines of questioning victims of the witchcraft trials faced. ${ }^{470}$ The questions were direct enough to make it clear what Thurzo wanted to hear, but were open enough that all of the accomplices were able to attempt what Craft called the "empty chair" defense. ${ }^{471}$ They laid the full blame for the crimes at the feet of Anna Durvulia, who was a friend and companion to Bathory from 1601 until Anna's death by a stroke in 1609. According to each of the accomplices, she was the one that instructed and encouraged the Countess and was therefore the one truly responsible for the atrocities against the girls. ${ }^{472} \mathrm{Craft}$ questioned how much of the testimony was actually true and how much of it was simply trying to divert the blame, but she never addressed the matter. "Empty Chair" defense aside, the bigger complication was pointed out by Thorne regarding the translation of the text. $^{473}$ The construction of the Hungarian language requires context to fully determine if

\footnotetext{
469 Those curious about the details of the trial of the accomplices should read Thorne's analysis. Although he did not intend for his work to be scholarly, his analysis of the questions, responses, and the trial in general is impressive. More time could not be dedicated to the accomplices' trials since it would distract too much from the main point of this thesis.

${ }^{470}$ Thorne, Countess Dracula, 39.

${ }^{471}$ Craft, Infamous Lady, 140.

472 Craft, Infamous Lady, 140.

${ }^{473}$ Craft, Infamous Lady, 139; Thorne, Countess Dracula, 39.
} 
a pronoun is he, she, or it. ${ }^{474}$ When speaking, or in the case of the accomplices being questioned, the context was clear or was clarified, but this did not translate into the transcript. The phrasing of the eleven questions made it very clear that Thurzo expected to hear about a woman, but the word which was used by the accomplices, asszony, translated into madam and was used to indicate any female superior. ${ }^{475}$ Therefore, there are times in the transcript when it was not completely clear that the "she" the accomplices were talking about was in fact the Countess and not Durvulia. ${ }^{476}$ Even with the unique oddities, the investigation of Bathory and the trial of her accomplices was done to the letter of the law by Thurzo.

But even if her investigation was legal, was her punishment of confinement legal? Confining Bathory had one particular advantage - it kept her head on her shoulders and therefore saved the family reputation. In just about every other way, however, it was risky and unusual. The type of strong central bureaucracy needed to run a penitentiary was not yet in place in Early Modern Europe, so confinement, unless it was in a convent or seminary, was usually a short term solution. One of the best examples of confinement as a punishment came from the Vatican Inquisition, which often used house arrest for first time female offenders who were repentant rather than execute or exile them for heresy. They were ordered to stay in their homes for two or three months and then their punishment was considered over. ${ }^{477}$ Until towers came into popular use a century later, however, confinement was an option only open to the wealthy mentally ill, who had the

\footnotetext{
${ }^{474}$ Eva Szabo Hungarian Practical Dictionary (New York: Hippocrene Books, 2005), 17.

475 Thorne, Countess Dracula, 39; Szabo, Hungarian Dictionary, 17-18.

476 Thorne, Countess Dracula, 39.

477 John Tedeschi, "Inquisitional Law and the Witch," in Early Modern European Witchcraft: Centres and Peripheries ed. Bengt Ankarloo and Gustav Henningsen (Oxford: Clarendon Press, 1990), 84.
} 
money to pay for care, relations who could care for them, and room to set aside to keep someone out of the public eye. ${ }^{478}$ Confining Bathory in her home, therefore, labeled her insane, which of course was how history remembered her. Craft discussed evidence, based on the pseudoscience of handwriting analysis, that Bathory may have had some kind of psychosis, including sadism, sexual dissatisfaction and schizophrenia. However there was no agreement between the experts who analyzed samples of her handwriting. ${ }^{479}$ Klara Acsova analyzed two different samples of her handwriting, one that she knew was the Countess' handwriting and a second unlabeled sample. Regarding the first, Acsova concluded,

Partially due to her decadent nature, but also as a result of sexual dissatisfaction, sadism overcame her more and more. Her sadism might have originated in unfulfilled love because she was forced to marry somebody other than whom she loved. This broke her and initiated increasing cravings for revenge in her. She was mischievous, dangerous and harmful to her surroundings...According to her handwriting, she was not schizophrenic or mad, as some of her biographers say. ${ }^{480}$

Around 1983, Acsova was asked by Szadeczky-Kardoss to do a second analysis,

this time without knowing who wrote the sample. Her conclusion this time was kinder.

She stated,

The writer was realistic, critical, hated resistance, and stood high above others. She was not so much loved as respected - not due to her cruelty but rather for her uncompromising attitudes, strictness and frequent humiliation of others. She required order in everything. The handwriting does not reveal any signs of sadism or sexual deviation, and does not reveal any signs of pathology except for occasional bouts of hysteria. However, the signature, coming right before she died and during her internment, bears signs of schizophrenia. ${ }^{481}$

\footnotetext{
${ }^{478}$ Judith S. Neuman, Suggestion of the Devil: Origin of Madness (Garden City: Anchor Books, 1975), 87.

${ }^{479}$ Craft, Infamous Lady, 187.

${ }^{480}$ Craft, Infamous Lady, 186. Sadly the date for the first interpretation is not stated.

${ }^{481}$ Craft, Infamous Lady, 187.
} 
Thomas Gugenberger analyzed two letters and concluded that while Bathory had good points, such as piety, generosity, and dignity, she also had strong sexual urges, was cruel, and prone to self-indulgence. ${ }^{482}$ He also noted that she was sadistic and had a mental disorder that was not named. ${ }^{483}$ The analysis of her handwriting confirms many of the oral legends recorded by early biographers, and the infamy of Bathory may have affected the objectivity of the analysts. But the oral legends themselves were usually unreliable anyway; after all, McNally and Penrose both recorded stories from the local villages that she was a mad woman and a vampire, but no such accusations were made in her investigation. ${ }^{484}$ The accuracy of these stories was questionable, and the question of her sanity remained debatable.

Considering her crimes, the modern mind has no trouble accepting that she was insane, but Early Modern understandings of insanity - both popular and elite - were different. Many popular cases of insanity were labeled as demonic possession, for which the only cure was the work of a priest. ${ }^{485}$ This perception was not held by the educated elite, however, who understood that mental illness was based in natural, not divine, events. ${ }^{486}$ While in physical health Galilean philosophy tempered humeral theory with practical knowledge of anatomy and physiology, the belief that blood, phlegm, yellow bile, and black bile worked in tandem to create a balanced mind was still strong. ${ }^{487}$ Seven types of mental illness were recognized as mostly natural including frenzy, anxiety,

\footnotetext{
${ }^{482}$ Craft, Infamous Lady, 188.

${ }^{483}$ Craft, Infamous Lady, 188.

${ }^{484}$ McNally, Dracula was a Woman, 12-13; Penrose, Bloody Countess, 8-9.

${ }^{485}$ Neuman, Suggestion, 36.

${ }^{486}$ Neuman, Suggestion, 20; Charles E. Gashen, Documentary History of Psychiatry: A Source Book on Historical Principles (London: Vision Press Limited, 1967), 6; Paracelsus, "Diseases that Deprive Man of his Reason," Four Treatises of Theophrastus van Hohulhien called Paracelsus trans. Dr. Gregory Ziltboorg in Gashen, Documentary History, 41.

${ }^{487}$ Neuman, Suggestion, 7. Gashen, Documents, 6.
} 
depression, and epilepsy. ${ }^{488}$ Generally, sufferers of these diseases were not declared possessed so long as they perfectly matched the identified symptoms of the disease. Even small deviations, such as epileptics turning their thumbs in instead of out, may have been enough to cause a doctor to recommend a priest. ${ }^{489}$ The extent to which the general populace understood the difference between mental illness and possession has not yet been conclusively settled, but it varied greatly depending on location. The French, in particular, were known to be quicker with the priest than the doctor, while in the Germanic states and Islamic nations, doctors were consulted first and priests only after other options were exhausted. ${ }^{490}$ Anxiety, frenzy, and epilepsy have all at one junction or another been included in Bathory's story, none more than epilepsy. McNally and Craft both stated that she had epilepsy, while Penrose and Thorne were more reserved and merely stated that it ran in the family. ${ }^{491}$ How Craft and McNally were so certain the Countess actually had the condition was unclear in their respective studies.

Depression and anxiety were seen as naturally occurring and considered easier to treat with dietary, lifestyle, or climate changes to re-establish the balance of humors. ${ }^{492}$ Some of the treatments used in the Early Modern era are still encouraged today, such as regular exercise, a diet based on moderation, and light or sound therapy to help those with depression and anxiety. Frenzy was more difficult to treat because the patient could be a danger to him or herself and others. Diets low in meat, cold baths to cool down the

\footnotetext{
${ }^{488}$ Neuman, Suggestion, 14.

${ }^{489}$ Owsei Temkin, The Falling Sickness: A History of Epilepsy from the Greeks to the Beginnings of Modern Neurology, $2^{\text {nd }}$ ed. (Baltimore: John Hopkins Press, 1971), 87, 141.

${ }^{490}$ Neuman, Suggestion, 5; Michael Stalberg, Experiencing Illness and the Sick Body in Early Modern Europe, trans. Leonhard Unglaub and Logan Kennedy (New York: Palgrave Macmillian, 2011), 10.

${ }^{491}$ McNally, Dracula was a Woman, 19; Craft, Infamous Lady, 13; Penrose, Bloody Countess, 17; Thorne, Countess Dracula, 118.

${ }^{492}$ Mary Lindemann, Medicine and Society in Early Modern Europe, 2nd ed. (Cambridge: Cambridge University Press, 2010), 14.
} 
blood, and blood-letting were the normal treatments for frenzy, but more often than not, those who suffered from frenzy or related psychosis, were the ones locked away for their own physical and social safety. ${ }^{493}$

Epilepsy was understood to have natural causes by elites, but the advice of doctors for suffers was to have their fits in private so as not to frighten the ignorant masses, indicating that this was not a popular understanding. ${ }^{494}$ Nobles, however, understood that epilepsy was hereditary and therefore worked hard to hide its presence in their children and family members because it could, and did, affect marriage possibilities and political power. ${ }^{495}$ Epilepsy and the more romantic term, Falling Sickness, were used interchangeably and largely inaccurately. Any disease that caused the patient to lose consciousness and convulse was called the Falling Sickness. Epilepsy was recognized as a specific malady with specific signs and symptoms. The difference can be broken down into all epilepsies are falling sicknesses, but not all falling sicknesses are epilepsies. ${ }^{496}$ Epilepsy was incurable for the Early Modern medical profession, but there were various treatments -- though the term must be used very loosely. The most common treatment was to rub the blood of a non-sufferer on the lips of an epileptic as a fit ended, or to mix the blood and piece of skull of a non-sufferer and give it to the victim as the fit ended.

\footnotetext{
${ }^{493}$ Phillip Barrough, "The Methods of phisiks, contanying the causes, signs, and cures of inward diseases in mans body from the head to the foote," in Three Hundred Years of Psychiatry 1535-1860: A History Presented in Selected English Texts ed. Richard Hunter and Ida Mocalpine (London: Oxford University Press, 1963), 25.

${ }^{494}$ Donald F. Scott, The History of Epileptic Therapy: An Accounts of How Medication was Developed. (Pearl River: Parthenon Publishing Group, 1993), 19; Temkin, History of Epilepsy, 89.

${ }^{495}$ Temkin, History of Epilepsy, 131.

${ }^{496}$ Temkin, History of Epilepsy, ix, 94.
} 
Religious talismans against epilepsy included wearing emeralds or mistletoe on the right hand or arm. ${ }^{497}$

It was very unlikely that Bathory or her family talked openly about her having the condition since it risked her marriageability and that of her children. If it was mentioned, it was done using flowery phrases such as fainting or even vapors. ${ }^{498}$ Even if a passage was discovered tying her to the Falling Sickness it could not be treated accurately as proof positive since, as stated, it did not translate directly to epilepsy. Additionally, epileptic fits that begin in childhood do not always continue after puberty, a recognized fact back then as one doctor informed his patients that there was no need for concern if a child suffers a fit, but if an adult does, he or she will suffer the disease for the rest of his or her life. $^{499}$

However, the possibility that she suffered from epilepsy - which she would have hidden - does offer some intriguing speculation about the largely unsolvable question of why she killed so many girls. Since blood was the most common treatment for epilepsy the tortures may have started as an attempt to treat herself without conferring with doctors. What started out as seeking medical treatment may have turned into a therapeutic release which in turn led to the horrific crimes of which she was accused. The major problem with this speculation, however, is that this treatment required Bathory to consume the blood, something her accomplices did not recount in their testimonies. The closest Bathory came to consuming blood was when she bit servants while she was ill.

\footnotetext{
${ }^{497}$ Tempkin, History of Epilepsy, 102, 176; Scott, History of Epileptic Therapy, 31.

${ }^{498}$ Tempkin, History of Epilepsy, 196.

${ }^{499}$ Barrough, "Methods of phisicks," 27.
} 
The question of Bathory's sanity will remain inconclusive without physical evidence, such as was done with Ivan the Terrible. ${ }^{500}$ No evidence was found in the few remaining letters and missives that a doctor was summoned or consulted to judge her sanity or attempt treatments. After she was confined, priests were summoned, not to exorcise the Countess, but to hear her confession, which was not forthcoming. ${ }^{501}$ Until such proof has been found, any statements regarding her health or sanity have been inconclusive and remain nothing but speculation.

But possible insanity may have helped more than hindered. The family argued that confinement was the solution to the problem of the Countess, and in many ways it was the best possible solution. Legally, she was dead and her actions no longer reflected poorly on the family. Demonstrative of this fact was the pristine reputation her husband enjoys as a Hungarian national hero. And the Nadasdy family's reputation recovered well enough that her grandson was able to marry into the powerful Esterhazy family which was nearly as old and as powerful as the Nadasdy and the Bathory clans. ${ }^{502}$ From that point of view, the only person for which confinement was not the best solution was the Countess herself. While the Enthusiasts avoided doing an in-depth analysis of what could have happened to Bathory had she gone to trial, the general consensus among them was that her noble status and the lack of physical evidence would have saved her. While her

\footnotetext{
${ }^{500}$ Czar Ivan the Terrible went mad in the final years of his reign. Centuries later, his body was given a toxicology exam and was found to have high levels of mercury. Mercury was a common treatment for syphilis so the prevailing explanation for his madness was syphilis and the side effects of mercury. www.newworldencyclopedia.org/entry/Ivan_IV_of_Russia.

${ }^{501}$ Craft, Infamous Lady, 135. In fact, Bathory blamed the Church - not Thurzo -- for her arrest and confinement.

${ }^{502}$ Judit Fejes, "The Marriage Policy of the Esterhazy Family after the Death of Palatine Miklos" in Peters, Beloved Children, 209, 211.
} 
noble status provided her with some legal protection, since a large percentage of the testimonies was inadmissible, it would not have saved her.

Had she been brought to trial, Bathory would have stood before a tribunal of noble peers as judges, including the king and the palatine, to answer for her crimes. She may have fallen back on her old defense of disease, and possibly even accused the church of conspiracy against her. According to Thorne, she may have also had to answer for charges of treason and witchcraft, although these charges were not selected by Matthias. ${ }^{503}$ It was unlikely that she would have had support from her children or from her extended family at a trial. Politically, their best move would have been to feed her to the wolves, so to speak, and hope that her condemnation admonished them socially and politically. Since the noble kindred was supposed to be a tight knit group of support, others may have also declined to give evidence in her favor. The fact that there was very little outrage from the noble world upon her initial arrest was indicative of how much support she could have expected. Her noble status would have done very little to help her with the king actively seeking to demonstrate his power by making her downfall an example.

There will always be the possibility that Bathory was acquitted; historically, however, that assertion was not supported. Noble women brought to trial did not usually emerge the successful party. Part of the reason for that was the supposed inferiority of women and the perception that they were prone to sin and vice by nature. Usually, however the woman was in the way of something someone else wanted. Since women

\footnotetext{
503 Thorne, Countess Dracula, 172.
} 
relied largely on male protection, even in Eastern Europe, when that protection was removed there was very little they could do for themselves.

Two cases that exemplified the reality of noble women on trial were Anna Bathory and Queen Joanna I of Spain. A Transylvanian relation of Elizabeth, Anna Bathory, demonstrated through her own experience what could have happened to the Countess. Meanwhile, earlier in the sixteenth century, Queen Joanna I of Spain provided a precedent for confinement of powerful noble women who were believed insane. The stories of both of these women demonstrated that in the grand scheme, the family agreement to confine the Countess was the best that could be hoped for, considering the situation, for not only herself but the family as well. They also contradict the assertion of the Enthusiasts that Bathory's noble status and power would have saved her.

Anna Bathory of Transylvania was put on trial for witchcraft, incest, and infanticide no less than three times, in 1618,1621 , and $1634 .^{504}$ While a woman being put on trial as a witch was not news, she was a noble woman and by the time of her second trial, the witchcraft craze had died out in Western Europe, but was really just getting started in Eastern Europe. ${ }^{505}$ Unlike the west, Eastern Europe was more concerned with the possibility of vampires than of witches, probably because in Eastern European traditions, witches had a significantly more positive community reputation and texts like the Malifus Maleficarum did not have same impact as they had in the West. ${ }^{506}$ With Eastern European witchhunts, the targets were wealthy, land holding, and politically powerful women instead of social outcasts who had few resources for their own

\footnotetext{
504 Thorne, Countess Dracula, 243-245.

${ }^{505}$ Klanicazy, "Hungary," 220.

506 Klanicazy, “Hungary,” 233.
} 
defense. ${ }^{507}$ Witchcraft accusations therefore were usually political ploys to remove a woman from power. In Anna's case, it worked. She was found guilty of witchcraft, including the murder of her son, still very much alive, and exiled first to Poland, then to Hungary ${ }^{508}$ Her property and all her moveable goods were confiscated by the state; in fact the prince of Transylvania, Gabor Bethlan, moved right into the Bathory seat after accusing Anna of using black magic to seduce him. ${ }^{509}$ Anna's trials effectively ended the Bathory nobility in Transylvania and she lived out the rest of her days as a charity case in Hungary with sympathetic friends. ${ }^{510}$

There were obvious significant differences between Anna's case and that of the Countess. Transylvania was an Ottoman ally and while the Principality considered itself to be the last bastion of Hungarian culture, to Royal and Ottoman-controlled Hungary, it was more often viewed as a traitor or sell-out. As the Ottoman Empire lost power in Eastern Europe, Transylvania was left increasingly vulnerable. Despite the frequent border conflicts and the Fifteen Years War, Royal Hungary was fairly safe and stable thanks to the support of the Hapsburg army and treasury. The political tension was much higher in Transylvania than in Hungary, which made for a more volatile social situation than in Hungary. Also unlike Elizabeth's case, Anna's accusers needed what she had. Bethlan wanted property and movable goods because Anna's brother, Andrew Bathory, was his strongest contender for Ottoman support of the Transylvanian throne. ${ }^{511}$ Anna's position and person therefore represented a true threat to men in power in a way that

\footnotetext{
507 Klanicazy, “Hungary,” 233.

508 Thorne, Countess Dracula, 245.

509 Thorne, Countess Dracula, 243.

510 Thorne, Countess Dracula, 245.

511 Thorne, Countess Dracula, 243-244.
} 
Elizabeth's did not. While Elizabeth was owed a substantial sum from Matthias, she was the one in greater need of money. Matthias and Thurzo gained nothing of material, significant political, or social value by actually trying Elizabeth, which was confirmed by the royal treasury. ${ }^{512}$ Anna was able to escape the charges and the country for a time by turning over everything she owned to Bethlan. Her situation, however, the repeat trials, the lack of support from other nobles, and the complete lose of noble status for all her relations, serve as an indicator of what Elizabeth herself may have experienced had she been brought to trial.

Spain was far from Hungary geographically and culturally, but both were part of the Holy Roman Empire, making the case of Queen Joanna I of Spain relevant due to Hapsburg involvement. Depending on who wanted to rule Spain in the early sixteenth century, Joanna I was or was not insane. When her father wanted to rule Spain, albeit indirectly through his daughter, she was perfectly sane and rational; but when her son came of age and had the power to counter his grandfather, his mother was a hysterical woman who had lost her mind when her husband had died and was not fit for the throne. ${ }^{513}$ This back and forth between the two men who were supposed to be in charge of her care after Phillip the Fair's death kept Joanna in and out of confinement until her son was finally able to put her back in successfully for the rest of her life. ${ }^{514}$ Unlike Elizabeth Bathory, who lived in confinement for about four years, Joanna ended up doing so for twenty years. ${ }^{515}$ Joanna was never accused of any particular crime, other than

\footnotetext{
512 Thorne, Countess Dracula, 174-175; Craft, Infamous Lady, 167 ; McNally, Dracula was a Woman, 85-86.

${ }^{513}$ Jansen, Monsterous Regiment, 74.

514 Jansen, Monsterous Regiment, 77.

515 Jansen, Monsterous Regiment, 77.
} 
insanity, and was put away in a convent. This may have been where the original idea for sending Bathory to a convent came from, though that has not been proven by the sources. But, it would have been a familiar idea to the Hapsburg family; Joanna was Emperor Charles V's mother, and the story of her insanity and confinement was not a family secret. $^{516}$

Once Bathory's case is put into context, with a deeper understanding of women's place in Eastern European Early Modern Society, and a less anachronistic concept of how the Early Modern judicial system functioned, the claims of conspiracy or irrational sexist fears supported by the Enthusiasts drop away. Considering her crimes and what exactly the family stood to lose if they allowed her to go to court, as exemplified by Anna Bathory, the decision to confine her and keep her from trial was the best possible outcome. Avoiding trial meant the family retained their noble status and all the lands and property that entailed. It also meant that Bathory did not face potentially humiliating accusations which, like Anna, could have been resurrected again and again if she was perceived as a threat. Perhaps more importantly, it spared the Countess from a public execution had she been found guilty. If there was any conspiracy, it was not based on the fact that she was a wealthy widow, and it was not based on a greedy land grab, it was based on balancing the needs of the family to protect its own status, powers, and members.

\footnotetext{
516 Jansen, Monsterous Regiment, 76.
} 


\section{CONCLUSION}

\section{BLOODLESS WATER}

The assertion of the Enthusiats that Countess Elizabeth Bathory was persecuted and targeted because of her gender and power status and was therefore targeted for an unfair trial was not supported by the historical evidence. Although she was indeed a powerful woman owed a large amount of money from King Matthias II, an unmarried woman in a position of power was not a cause for fear among Hungarians. Poland and Hungary were more accepting of the virago, or strong woman, and it was not only accepted but expected that noble women took control of their estates especially in the absence of their husbands. The reason she was investigated was not because of a conspiracy, but because there was enough evidence of criminal activity against her that even her exalted position did not protect her.

Even outside of Hungary, the single woman who had power was not as unusual or shocking as popular belief had argued. France, England, Scotland, and Spain, as well as provinces of the Italian peninsula were all ruled by widows or single women, either directly as in England or as regents as in France. Female rulers and nobles who ruled with the intention of preserving or expanding family power for their children were praised for their efforts without risking their femininity. As a widow, Bathory did not violate that 
perception as she continued to assist in administrative duties while her son was still under his full age. Gradually however, she retreated, as was expected, from those duties as her son grew up and married. Therefore, even by Western standards she was not considered dangerous or troublesome and would not have been targeted only because she was a widowed noble woman.

Noble privileges in Hungary were not exclusive to men, except in certain instances regarding inheritance. A noble woman could depend on having the same rights and privileges as her husband and other male relations, including the right to distribute her earthly goods as she saw fit, such as debts. The original debt was to her husband, and Bathory merely continued the campaign for repayment; meanwhile, removing her from power did not in any way negate the debt since her son could claim it. To accomplish the full negation of King Matthias' debt, the entire Bathory and the senior Nadasdy branch would have had to be removed from their noble standing. Therefore, because the fear of powerful women did not exist in Eastern Europe as it did in Western Europe, and because the debt to the king would not have been cancelled because Bathory was arrested, the theory that she was targeted for either of these reasons has no support.

While it is true that Bathory was never brought to trial for her alleged crimes and was never given a formal summons notifying her that she was being investigated for suspected crimes, the fact remained that because of the type of crime she was accused of, she did not have to be. The Tripartitum clearly stated that it was the right of every noble to receive formal summons regarding any investigation against them, and that only the king and the palatine could try and judge a noble -- unless the crime involved was murder. In that case there was no need for a summons, and in fact it was far more 
advantageous that Bathory not be told she was being investigated. Had she been able to escape Hungary, which letters to the King of Poland suggest she may have been planning on doing, she would have escaped punishment entirely, though her actions would have caused even more suspicion to fall on her. Since the charge against her was murder, not only of serfs, but of nobles as well, neither Thurzo nor any other representative of the king needed to make the arrest; any peasant could have done it. Because of this loophole regarding the loss of noble privileges if charged with murder, Thurzo did not break any laws when he entered castle Cjesthe or made the decision to put her under house arrest. Thurzo stood to gain nothing by removing Bathory from power since her son was already in charge of everything except her dower, Cjesthe.

Preventing Bathory from going to trial did not ruin the standing of the family, but saved it. Once Bathory was legally dead, her crimes no longer harmed the family and she could not be brought to trial. This was exactly the agreement Thurzo had made with Paul Nadasdy and his brother-in-laws: act before the Diet had too much time to question him, keep Bathory out of the courtroom, and protect the property and honor of the family. By following this agreement, Thurzo carried out not only his elected duty, acting as a buffer to protect the rights of the Hungarian nobles from a foreign king, but also the death bed charge he had been given by Francis. He would have failed in both of these offices had he allowed her to go to trial, where she would have been accused on largely hearsay evidence. Had she been found guilty, she would have been beheaded and the whole family would have been implicated and lost their noble standing. Even if she had been acquitted, her children and grandchildren may have never recovered from the social stigma that followed. Thurzo would have failed to protect his fellow nobles from the 
king, and he would have failed to look after Francis's family. Claims by the Enthusiasts, particularly McNally, Craft, and Thorne, that Thurzo failed in his duty or was part of a Hapsburg driven power grab against Bathory were not supported by historical facts and legal norms.

Bathory's four accomplices, Janos, Ilona, Katalin, and Dorottya did not face a show or sham trial despite the use of torture. Judicial torture was not a secret, and often it was not even noted by clerks because it was simply assumed to have been used. Torture ranged from demonstrations of what would happen to psychological torture to using machines that had the potential to maim and cripple the victims. The sort of torture the accomplices were exposed to was not the extreme, intense, infamous sessions associated with the witchcraft trials. While the four were found guilty of a shocking crime, they were not accused of heresy which allowed for such extended torture. Additionally, the accomplices would not have been held to their testimony until after they recovered from their torture sessions. Had they denied their confessions under torture three times, they would have been acquitted of their charges. Because of the rapid turn over between arrest and trial, it was unlikely that the accomplices underwent many torture sessions, but it will never be known for certain what methods were used. Regardless, each of the accomplices confessed to their part in the crimes of Bathory and were able to give details about the murders, even though it was not always immediately clear that it was Bathory who ordered the atrocities.

The evidence from the trial and the procedures laid out by the Tripartitum all indicate that Thurzo acted well within his rights as palatine in regards to the investigation of the Countess, his raid on and arrest at Cjesthe, and the trial and execution of the four 
accomplices. Claims by enthusiasts of Bathory that state otherwise have not properly taken into account the Early Modern European judicial system, or the place of torture within it. Instead they have grafted anachronistic, modern ideas of justice and human rights onto the past. As with the claims that Bathory was targeted because she was a powerful widow, the historical evidence does not support the idea that the accomplices faced a sham trial.

The legend of Countess Elizabeth Bathory will never be conclusively resolved; her guilt or innocence will always be questioned, and she will always have a special place within the hearts of students and fans of the occult. Her name will always be tied with blood bathing, vampires, werewolves, and abuse of noble power. None of this, however, should prevent serious historians from examining her case and using its infamy to help educate students on the place of women within the Early Modern context, particularly in the rarely studied Eastern European framework, as well as the strengths and weaknesses of the Early Modern system of justice. 
APPENDIX

PERSON OF IMPORTANCE

The Bathory and Nadasdy Families

- Elizabeth Bathory

Accused of torturing between 50 and 650 girls to death in the basements, kitchens, and bathhouses of her castles, particularly Castle Cjesthe. She was placed under house arrest by Thurzo, confined to a suite of rooms from 1610. She was found dead in Mid-August, 1614.

- Francis Nadasdy

Elizabeth's husband and a national hero for Hungary. He was immensely involved in the Long War and was given the position of High Stable Master in recognition of his service. The only son of Palatine Thomas Nadasdy and Ursula Nadasdy, Francis inherited a vast fortune from them before he married Elizabeth. He died of illness on January 4, 1604. On January 3, 1604, he wrote to his friend, George Thurzo, asking him to protect his wife and family 
- Paul Nadasdy

Only surviving son of Elizabeth and Francis. He was involved with the negotiation of an agreement with Palatine Thurzo to keep his mother from trial.

- Gabor Bathory

The king of Poland and Elizabeth's nephew and cousin. He was willing to grant her safe passage into Poland, but she never took him up on his offer. He was in an on-again-offagain war with Matthias II. His relation to Bathory may have made her a target for the king.

- Steven Bathory

Elizabeth's eldest brother, who died childless not long after Francis in 1605. Supposedly he was a lecher and a drunk who liked to pick fights and run through the town naked.

- Klara Bathory

Elizabeth's aunt. Supposedly Elizabeth was her favorite niece and was taken under her wing. Klara's actual involvement with Elizabeth is questionable since she married an Italian noble and only visited occasionally. Legend says that she was a bi-sexual, a witch, and a murderess.

- Anna Bathory of Transylvania

Elizabeth's cousin in Transylvania who was accused of witchcraft no less than three times. Anna was forced to turn over the Bathory seat in Transylvania, effectively ending 
the noble line. She is an example of what could have happened to Elizabeth if she had gone to court.

\section{The Law and Accusers}

- King Matthias II

Brother of Emperor Rudolf II. He was King of Hungary as his brother's heir apparent. After Rudolf was found unfit for leading, he became Emperor. King Matthias ordered the investigation against Elizabeth Bathory regarding rumors of many mysterious deaths. After she was placed under house arrest he continued to press to have her brought to trial for murder, each time being told it was worthless. His on again off again war with King Gabor Bathory of Poland has been cited as the reason he focused on Elizabeth so much. Others claim that he targeted her because she was a wealthy and land powerful widow. Finally, the Hapsburg family owed the Nadasdy family a great deal of money for a loan given during the Turkish war. Some believe that Matthias sought to negate the need to pay the debt by having her removed from power.

- Palatine George Thurzo

Elected Palatine as a compromise candidate, Thurzo was given the task of investigating Bathory by Matthias. Although his inquiries found nothing more than rumor and hearsay, he moved forward to arrest her. But first, he informed Paul Nadasdy and his brothers in law of the rumors going around. Together all three of them agreed to allow Thurzo to place Elizabeth under house arrest and execute the accomplices without argument from 
the family so long as Thurzo kept Bathory from actually going to trial. Thurzo was also best friends with Francis Nadasdy at court, served with him during the Long War, and was charged with protecting his family on Francis' death.

\section{- Imre Megyeri}

Paul Nadasdy's tutor and legal guardian after 1604. He and Bathory did not like each other. Imre was part of the raid on Cjesthe, and possibly the reason she was not sent to a convent as originally planned. Imre threatened to reveal the truth to Matthias if Bathory was not locked away.

\section{- Janos Ponikenusz}

The local priest of Cjesthe. He was the author of a letter to Matthias reporting Bathory's crimes. He claimed to have found the bodies of nine girls in the catacombs that linked Cjesthe and his chapel. He was part of the New Year's Eve raid and one of the original thirty-six witnesses.

\section{- Benedek Deszo}

Also written as Benedikt Deseo. A steward of Sarvar who gave a detailed account of three murders he had seen. He is the only known male eye-witness to Bathory's abuse. He gave a total body count of 175 victims. 


\section{The Accomplices}

\section{- Anna Durvulia}

Bathory's friend and confidant after Francis died. Very little is known about her except that she was Croatian. She may have been a witch and taught Bathory about the occult. According to the other accomplices, she taught Bathory how to beat a girl to death and lead many of the torture sessions. She died of a stroke in 1609.

\section{- Ilona Jo}

Bathory's accomplice and wet nurse to all of Elizabeth's children. She was arrested during the raid, confessed to the crime of murder, and was executed. Her confession named a total of 50 victims and detailed Durvulia's involvement. She was publicly executed by having her hands cut off before being burned at the stake.

\section{- Janos Fiziko}

Also known as the Dwarf. He confessed that he brought Bathory her victims along with Ilona. He was not involved with the actual torture process since he was not allowed inside the room. Because he was a teenager at the time of his arrest, he was beheaded rather than burned at the stake. He gave a total number of victims of 45 .

\section{- Katalin Beneczky}

The least involved of the accomplices, and the only one to avoid execution. She was mainly responsible for getting rid of the bodies and cleaning up afterwards rather than 
actually torturing them. She was sentenced to life in prison, but she was released after a few years and disappeared. She reported that in her time with the Countess she saw 35 girls killed.

\section{- Dorottya Szentes}

Involved nearly as long as Ilona Jo, and a long time servant for Bathory. Other accomplices reported that she was cruelest of all and enjoyed the tortures even more than Durvulia or Bathory. She too confessed, placed most of the blame on Durvulia, and gave a victim total of 55 . She was executed the same way as Ilona Jo. 


\section{BIBLIOGRAPHY}

\section{$\underline{\text { Primary Sources }}$}

Adams, Thomas. The Blacke Devil or the Apostate Together with the Wolfe Worrying the Lambes. And the Spiritual Navigator, Bound for the Holy Land. In three sermons. London: William Iaggard. 1615.

Fonte, Moderata and Virgina Cox. The Worth of Women: Wherein is Clearly Revealed Their Nobility and Their Superiority to Men. Chicago: University of Chicago Press, 1997.

Fumee, Martin. Historie of the Troubles of Hungarie: Containing the Pitifull Losse and Ruine of that Kingdome, and the Warres Happened there in that time, betweene the Christians and Turks. Translated by R.C. Gentleman. London, 1600.

Paget, John. Hungary and Transylvania; With Remarks on their Condition, Social, Political, and Economical. Philadelphia: Lea \& Blanchard, 1850.

Platt, Hugh. Delightes for Ladies. London, 1609.

Sanitates, Tocuinum. The Medieval Health Handbook. Translated by Oscar Rotti and Adele Westbrook. New York: George Braziller Inc., 1976.

Siegemund, Justine and Lynne Tatlock. The Court Midwife. Chicago: University of Chicago Press, 2005.

Stearne, John. A Confirmation and Discovery of Witchcraft. London, 1648.

Werboczky, Stephen. The Customary Law of The Renowned Kingdom of Hungary in Three Parts. Translated by Janos M. Bak, Peter Banyo, and Martyn Rady. Budapest: Central European University, 2005.

\section{$\underline{\text { Secondary Sources }}$}

Adams, Tracy. "Notions of Late Medieval Queenship: Christine de Pizan's Isabeau of Bavaria." In The Role of Women in Early Modern Europe, edited by Anne J. Cruz and Mihoko Suzuki, 13-29, Urbana: University of Illinois Press, 2009.

van Arsdall, Anne. Medieval Herbal Remedies: The Old English Herbarium and AngloSaxon Medicine. New York: Routledge, 2002.Asch, Ronald G. Nobility in Transition 
1550-1700: Courtiers and Rebels in Britain and Europe. London: Arnold Publishing, 2003.

Barber, Paul. "Forensic Pathology and the European Vampire." In The Vampire: A Casebook, edited by Alan Dundes, 109-142, Madison: University of Wisconsin Press, 1998.

Baraz, Daniel. Medieval Cruelty: Changing Perceptions, Late Antiquity to the Early Modern Period. Ithaca: Cornell University Press, 2003.

Barbogli, Marzio and David I. Kertzer. "Introduction.” In The History of the European Family Volume One: Family Life in Early Modern Times, 1500-1789, edited by David I. Kertzer and Marzia Barbogli, ix-xxxii. New Haven: Yale University Press, 2001.

Baring-Gould, Sabine. The Book of Werewolves: Being an Account of a Terrible Superstition. Mineola, N.Y.: Dover Publications, 2006.

Barnes, Linda L. Needles, Herbs, Gods, and Ghosts: China, Healing and the West to 1848. Cambridge: Harvard University Press, 2005.

Barrough, Phillip. "The Methods of phisiks, contanying the causes, signs, and cures of inward diseases in mans body from the head to the foote." In Three Hundred Years of Psychiatry 1535-1860: A History Presented in Selected English Texts, edited by Richard Hunter and Ida Mocalpine, 24-28, London: Oxford University Press, 1963.

Bergdolt, Klaus. Wellbeing: A cultural History of Healthy Living. Maldem: Polity, 2008.

Bonfield, Lloyd. "Developments in European Family Law." In The History of the European Family Volume One: Family Life in Early Modern Times, 1500-1789, edited by David I. Kertzer and Marzia Barbogli, 87-124, New Haven: Yale University Press, 2001.

Bogucka, Maria. Women in Early Modern Polish Society Against the European Background. Burlington: Ashgate Publising Company, 2004.

Buranbaeve, Oksana and Vanja Mlandino. Culture and Customs of Hungary. Santa Barbara: Greenwood Press, 2011.

Carroll, Stuart. Blood and Violence in Early Modern France. New York: Oxford University Press, 2006.

Carson, Richard. Fashions in Makeup: From Ancient to Modern Times. New York: Universe Books, 1972. 
Cartedge, Bryan. The Will to Survive: A History of Hungary. New York: Columbia University Press, 2011.

Conrad, Lawerence. The Western Medical Tradition 800 BC - 1800 AD. New York: Cambridge Press. 1995.

Craciun, Maria. Communities of Devotion: Religious Order and Society in East Central Europe, 1450s-1800. Farnham: Ashgate, 2011.

Craft, Kimberly. Infamous Lady: The True Story of Countess Erzsebet Bathory. Lexington: Kimberly Craft, 2009.

Craft, Kimberly L. The Private Letters of Countess Erzsébet Báthory. Lexington: Kimberly Craft, 2011.

Cruz, Anne J. and Mihoko Suzuki. The Rule of Women in Early Modern Europe. Urbana: University of Illinois, 2009.

Deak, Eva. "'Princeps non Principessa': Catherine of Brandenburg, Elected Prince of Transylvania (1629-1630)." In The Role of Women in Early Modern Europe, edited by Anne J. Cruz and Mihoko Suzuki, 80-99. Urbana: University of Illinois Press, 2009.

Dean, Trevor. Crime in Medieval Europe 1200-1550. Harlow: Pearson Education Limited, 2001.

Dégh, Linda. Folktales of Hungary. Translated by Judit Halász. Chicago: University of Chicago Press. 1965.

DeWold, Johnathon. The European Nobility, 1400 - 1800. Cambridge: Cambridge University Press, 1996.

DiCaprio, Lisa and Merry E. Wiesner, eds. Lives and Voices: Sources in European Women's History. Boston: Haughton Mifflin Company, 2000.

Dolen, Frances E. "Gender and Sexuality in Early Modern England." In Gender, Power, and Privilege in Early Modern Europe, edited by Jessica Munns and Penny Richards, 7-21. London: Pearson Education Limited, 2003.

Domotor, Tekla. Hungarian Folk Beliefs. Bloomington: Indiana University Press, 1982.

Donahue, Charles. The Records of the Medieval Ecclesiastical Courts. Berlin: Duncker and Humblot, 1989. 
Elmer, Peter. The Healing Arts: Health, Disease, and Society in Europe, 1500-1800. Manchester: Manchester University Press, 2004.

Engel, Pal. "The Late Medieval Period, 1382-1526." In A History of Hungary: Millennium in Central Europe, edited by Laszlo Kontler, 60-84, New York: Palgrave Macmillan, 2002.

Fairchilds, Cissie. Women in Early Modern Europe 1500-1700. Harlow: Pearson Longman, 2007.

Fazekos, Istvan. "Count Adam Batthyany I and his Children." In Beloved Children: History of Aristocratic Childhood in Hungary in the Early Modern Age, edited by Katalin Peter, translated by Rachel and Janos Hideg, 163-198, Budapest: Central European University Press, 2001.

Fejes, Judit. "The Marriage Policy of the Esterhazy Family After the Death of Palatine Miklos." In Beloved Children: History of Aristocratic Childhood in Hungary in the Early Modern Age, edited by Katalin Peter, translated by Rachel and Janos Hideg 199-250. Budapest: Central European University Press, 2001.

Fota, Marta. “'Wider den grousamen Erbfeind deB Christliden Nahmaas': Lutheran Military Chaplains from Wurttemberg in the Hungarian Wars against the Ottoman Empire in the Sixteenth and Seventeenth Centuries." Translated by Julia Riedel. In Friars, Nobles and Burghers - Sermons, Images and Prints: Studies of Culture and Society in Early Modern Europe. In Memorium Istvan Gyorgy Toth, edited by Jaroslav Miller and Laszlo Kontler, 73-89. New York: Central European University Press, 2010.

Fugedi, Erik. The Elefanthy: The Hungarian Noblemen and His Kindred. Translated by Csoba Farkas. Budapest: Central European University Press, 1998.

Gashen, Charles E. Documentary History of Psychiatry: A Source Book on Historical Principles. London: Vision Press Limited, 1967.

Giannangelo, Stephen J. The Psychopathology of Serial Murder: A Theory of Violence. Westport: Praeger Publishers, 1996.

Gibson, Dirk C. Legends, Monsters, or Serial Murderers? The Real Story Behind and Ancient Crime. Santa Barbara: Praeger Publishers, 2012.

Greenshields, Malcom. An Economy of Violence in Early Modern France: Crime and Justice in the Haute Auvergne, 1587-1664. University Park: Pennsylvania State University Press, 1994. 
Gunn, Fenja. The Artificial Face: A History of Cosmetics. New York: Hippocrene Books Inc. 1983.

Hanawalt, Barbara A. Growing Up in Medieval London: The Experience of Childhood in History. New York: Oxford University Press, 1993.

Hardwick, Julie. "Did Gender have a Renaissance? Exclusions and Traditions in Early Modern Western Europe." In A Companion to Gender History, edited by Teresa A. Meade and Merry E. Wiesner-Hanks, 343-357, Molden: Blackwell Publishing, 2004.

Hartman, Joan E. "Introduction.” In Structures and Subjectivities: Attending to Early Modern Women, edited by Joan E. Hartman and Adele Suff, 3-16, Newark: University of Delaware Press, 2007.

Herlihy, David. "Did Women Have a Renissance? A Reconsideration.” In Women, Family and Society in Medieval Europe: Historical Essays 1978-1991, edited by David Herlihy, 33-56, Providence: Berghahrn Books, 1995.

Herlihy, David. "The Natural History of Medieval Women." In Women, Family and Society in Medieval Europe: Historical Essays 1978-1991, edited by David Herlihy, 57-68, Providence: Berghahrn Books, 1995.

Herlihy, David. "Women's Work in the Towns of Traditional Europe." In Women, Family and Society in Medieval Europe: Historical Essays 1978-1991, edited by David Herlihy, 69-95, Providence: Berghahm Books, 1995.

Herlihy, David. "Family." In Women, Family and Society in Medieval Europe: Historical Essays 1978-1991, edited by David Herlihy, 113-134, Providence: Berghahm Books, 1995.

Herlihy, David. "The Making of the Medieval Family: Symmetry, Structure and Sentiment." In Women, Family and Society in Medieval Europe: Historical Essays 1978-1991, edited by David Herlihy, 135-153, Providence: Berghahm Books, 1995.

Herlihy, David. "The Family and Religious Ideologies in Medieval Europe." In Women Family and Society in Medieval Europe: Historical Essays 1978-1991, edited by David Herlihy, 154 - 173, Providence: Berghahm Books, 1995.

Herlihy, David. "Medieval Children." In Women, Family and Society in Medieval Europe: Historical Essays 1978-1991, edited by David Herlihy, 215 - 243, Providence: Berghahm Books, 1995. 
Herlihy, David. "Biology and History: Suggestions for a Dialogue." In Women, Family and Society: Historical Essays 1978-1991, edited by David Herlihy, 247 - 260, Providence: Berghahm Books, 1995.

Herlihy, David. “Age, Property and Career in Medieval Society.” In Women, Family and Society: Historical Essays 1978-1991, edited by David Herlihy, 261 - 278, Providence: Berghahm Books, 1995.

Herman, Eleanor. Sex with the Queen: Nine Hundred Years of Vile Kings, Virile Lovers, and Passionate Politics. New York: Harper Perennial, 2007.

Hole, Robert and Anthony Bolin. “The Female Serial Killer.” In Contemporary Perspectives on Serial Murder, edited by Ronald M. Holmes and Stephan T. Holmes, 33-58, Thousand Oaks: Sage Publications, 1998.

Holmes, Ronald M. Holmes and James E. DeBurger. "Profiles in Terror: The Serial Murderer." In Contemporary Perspectives on Serial Murder, edited by Ronald M. Holmes and Stephan T. Holmes, 5-16, Thousand Oaks: Sage Publications, 1998.

Holmes, Stephen E., Eric Hickey, Ronald M. Holmes. "Female Serial Murderesses: The Unnoticed Terror." In Contemporary Perspectives on Serial Murder, edited by Ronald M. Holmes and Stephan T. Holmes, 59-70. Thousand Oaks: Sage Publications, 1998.

Housley, Norman. Religious Warfare in Europe 1400-1536. London: Oxford University Press, 2002.

Hunt, Janin. Medieval Justice: Cases and Laws in France, England and Germany 5001500. Jefferson: McFarland and Company, 2004.

Hunt, Margret R. "Women in Ottoman and Western European Law Courts: Were Western Women Really the Luckiest Women in the World?" In Structures and Subjectivities: Attending to Early Modern Women, edited by Joan E. Hartman and Adele Suff, 176-199. Newark: University of Delaware Press, 2007.

Innes, Brian. The History of Torture. New York; St. Martins' Press, 1998.

Jansen, Sharon L. The Monstrous Regiment of Women: Female Rulers in Early Modern Europe. New York: Palgrave Macmillian, 2002.

Kaplan, Benjamin J. Divided by Faith: Religious Conflict and the Practice of Toleration in Early Modern Europe. Cambridge: Belknap Press of Harvard University Press, 2007. 
Kaser, Karl. "Serfdom in Eastern Europe." In The History of the European Family Volume One: Family Life in Early Modern Times, 1500-1789, edited by David I. Kertzer and Marzia Barbogli, 24-62. New Haven: Yale University Press, 2001.

Kaspersson, Maria. "Prosecution and Public Participation - The Case of Early Modern Sweden." In Crimes, Law, and Popular Culture in Europe 1500-1900, edited by Richard McMahon, 96 - 117. Portland: William Publishing, 2008.

Kelleher, Michael D. and C.J. Kelleher. Murder Most Rare: The Female Serial Killer. Westport: Praeger Publishers, 1998.

Kent, Susan Kinglsy. "Gender Rules: Law and Politics.” In A Companion to Gender History, edited by Teresa A. Meade and Merry E. Wiesner-Hanks, 86-109. Molden: Blackwell Publishing, 2004.

King, Margert L. and Albert Rabil. Teaching Other Voices: Women and Religion in Early Modern Europe. Chicago: University of Chicago Press, 2007.

King, Ursula. "Religion and Gender: Embedded Patterns, Interwoven Frameworks." In A Companion to Gender History, edited by Teresa A. Meade and Merry E. WiesnerHanks, 70-85, Molden: Blackwell Publishing, 2004.

Klaniczay, Gabor. "The Accusations and the Universe of Popular Magic.” In Early Modern European Witchcraft: Centres and Peripheries, edited by Bengt Ankarloo and Gustav Henningsen, 219-255, Oxford: Clarendon Press, 1990.

Kogay, Donald J. "Introduction." In The Final Argument: The Imprint of Violence on Society in Medieval and Early Modern Europe, edited by Donald J. Kogay and L.J. Andrew Villalon, xv-xx, Woodbridge: The Boydell Press, 1998.

Kollman, Nancy Shields. "Self, Society, and Gender in Early Modern Europe." In A Companion to Gender History, edited by Teresa A. Meade and Merry E. WiesnerHanks, 358-370, Molden: Blackwell Publishing, 2004.

Kontler, Laszlo. A History of Hungary: Millennium in Central Europe. New York: Palgrave Macmillan, 2002.

Lanser, Susan S. “The Political Economy of Same Sex Desire.” In Structures and Subjectivities: Attending to Early Modern Women, edited by Joan E. Hartman and Adele Suff, 157-175, Newark: University of Delaware Press, 2007.

LaPrete, Kimberly A. "The Gender of Lordly Women: The Case of Adela of Blais." In Pawns or Players: Studies on Medieval and Early Modern Women, edited by Christine Meeks and Catherine Lawless, 90-110, Dublin: Four Courts Press, 2003. 
LaPrete, Kimberly A. "Gendering Viragos: Medieval Perceptions of Powerful Women." In Victims or Viragos? Studies on Medieval and Early Modern Women Four, edited by Christine Meeks and Catherine Lawless, 17-38, Portland: Four Courts Press, 2005.

Laszkiewicz, Hubert M. Churches and Confessions in East Central Europe in Early Modern Times. Lubin: Instytuf Europy Srodkowo Wschadniej, 1999.

Lavrenavic, Dubravko. "Hungary and Bosnia 1387-1463: Between Stereotypes and New Interpretations," In Friars, Nobles and Burghers - Sermons, Images and Prints: Studies of Culture and Society in Early Modern Europe. In Memorium Istvan Gyorgy Toth, edited by Jaroslav Miller and Laszlo Kontler, 33-46, New York: Central European University Press, 2010.

Lehmann, Hartmut. "The Fourteenth, the Seventeenth and the Twentieth Centuries as Centuries of Violence and Mass Death." In Power Violence and Mass Death in Pre-Modern and Modern Times, edited by Joseph Canning, Hartmut Lehmann and Jay Winter, 1-5, Hampshire: Ashgate Publishing Limited, 2004.

Lehmann, Hartmut. "Under the Spell of Mars: Power Violence, and Mass Death in Seventeenth Century Europe." In Power Violence and Mass Death in Pre-Modern and Modern Times, edited by Joseph Canning, Hartmut Lehmann and Jay Winter, 93-95, Hampshire: Ashgate Publishing Limited, 2004.

Lindeman, Mary. Medicine and Society in Early Modern Europe. Cambridge: Cambridge University Press. 2010.

Lougu, Carolyn C. "Its Frequent Visitor: Death at Boarding School in Early Modern Europe." In Women's Education in Early Modern Europe: A History 1500-1800, edited by Barbara J. Whitehead, 193-224, New York: Garland Publishing Inc., 1999.

Lunde, Donald T. Murder and Madness. San Francisco: San Francisco Book Company, Inc., 1976.

Lynn, John A. Women, Armies, and Warfare in Early Modern Europe. New York: Cambridge University Press, 2008.

Madean, Ian. The Renaissance Notion of Women: A Study in the Fortunes of Scholasticism and Medical Science in European Intellectual Life. Cambridge: Cambridge University Press, 1980.

Maumann, Markus. "The Experience of Violence and the Expectation of the End of the World in Seventeenth - Century Europe." In Power Violence and Mass Death in 
Pre-Modern and Modern Times, edited by Joseph Canning, Hartmut Lehmann and Jay Winter, 141-159. Hampshire: Ashgate Publishing Limited, 2004.

McMahon, Richard. "Introduction." In Crimes, Law, and Popular Culture in Europe 1500-1900, edited by Richard McMahon, 1-22, Portland: William Publishing, 2008.

McNally, Raymond T. Dracula was a Woman: In Search of the Bloody Countess of Transylvania. New York: McGraw Hill, 1983.

McNally, Raymond and Rodu Florescu. "Vampirism: Old World Folklore." In The Vampire in Slavic Culture, Revised Edition, edited by Thomas J. Garza, 41-52, San Diego: Cognella, 2012.

Meade, Teresa A. "Structures and Meanings in a Gendered Family History." In A Companion to Gender History, edited by Teresa A. Meade and Merry E. WiesnerHanks, 51-69, Molden: Blackwell Publishing, 2004.

Meek, Christine and Catherine Lawless. "Introduction.” In Victims or Viragos? Studies on Medieval and Early Modern Women Four, edited by Christine Meeks and Catherine Lawless, 9-16, Portland: Four Courts Press, 2005.

Michalove, Sharon D. "Equal Opportunity? The Education of Aristocratic Women, 14501540.” In Women's Education in Early Modern Europe: A History 1500-1800, edited by Barbara J. Whitehead, 47-74, New York: Garland Publishing Inc., 1999.

Miller, Jaroslav and Laszlo Kontler. Friars, Nobles and Burghers - Sermons, Images and Prints: Studies of Culture and Society in Early Modern Europe. In Memorium Istvan Gyorgy Toth. New York: Central European University Press, 2010.

Miller, Pavla. "Gender and Education before and after Mass Schooling." In A Companion to Gender History, edited by Teresa A. Meade and Merry E. Wiesner-Hanks, 129145, Molden: Blackwell Publishing, 2004.

Molnar, Miklos. A Concise History of Hungary. Translated by Anna Magyer. Cambridge: Cambridge University Press, 2001.

Morrison, Helen and Harold Goldberg. My Life Among the Serial Killers: Inside the Minds of the World's Most Notorious Murderers. New York: Harper Collins Publishers, 2004.

Munns, Jessica. "Introduction.” In Gender, Power, and Privilege in Early Modern Europe, edited by Jessica Munns and Penny Richards, 1-6. London: Pearson Education Limited, 2003. 
Navey, Samual. The Second Look: The Reconstruction of Personal History in Psychiatry and Psychoanalysis. Baltimore: The John Hopkins Press, 1968.

Neuman, Judith S. Suggestion of the Devil: The Origin of Madness. Garden City: Anchor Books, 1975.

Neville, Cynthia J. "War, Women and Crime in Northern English Border Lands in the Later Middle Ages." In The Final Argument: The Imprint of Violence on Society in Medieval and Early Modern Europe, edited by Donald J. Kogay and L.J. Andrew Villalon, 163-175, Woodbridge: The Boydell Press, 1998.

Nicholas, David. The Domestic Life of a Medieval City: Women, Children, and the Family in Fourteenth Century Ghent. Lincoln: University of Nebraska Press, 1985.

Orme, Nicholas. Medieval Children. New Haven: Yale University Press, 2001.

Orr, Patricia R. "Non Patest Appellum Focere: Criminal Charges Women Could Not But Did - Bring in Thirteenth Century English Royal Courts of Justice." In The Final argument: The Imprint of Violence on Society in Medieval and Early Modern Europe, edited by Donald J. Kogay and L.J. Andrew Villalon, 141-160, Woodbridge: The Boydell Press, 1998.

Ozment, Steven. The Burgermeister's Daughter: Scandal in a Sixteenth Century German Town. New York: St. Martin's Press. 1996.

Palffy, Geza. The Kingdom of Hungary and the Hapsburg Monarchy in the Sixteenth Century. Translated by Thomas J. and Helen D. DeKarnfeld. New York: Columbia University Press, 2009.

Parish, Helen L. and William G. Naphy. Religion and Superstition in Reformation Europe. New York: Manchester University Press, 2002.

Penrose, Valentine. The Bloody Countess. Translated by Alexander Trocchi. London: Colder and Boyors, 1970.

Petenyi, Sandar. Games and Toys in Medieval and Early Modern Hungary. Translated by Alice M. Choyke and Laszlo Bartosivicz. Kapite: Krems, 1994.

Peter, Katalin. "The Later Ottoman Period and Royal Hungary 1606-1711." In A History of Hungary, edited by Peter F. Sugar, Peter Hanak, and Tibor Franks, 100-120. Bloomington: Indiana University Press, 1990. 
Peter, Katalin. "Introduction." In Beloved Children: History of Aristocratic Childhood in Hungary in the Early Modern Age, edited by Katalin Peter, translated by Rachel and Janos Hideg 1-18, Budapest: Central European University Press, 2001.

Peter, Katalin. "Historical Background.” In Beloved Children: History of Aristocratic Childhood in Hungary in the Early Modern Age, edited by Katalin Peter, translated by Rachel and Janos Hideg 19-38, Budapest: Central European University Press, 2001.

Peter, Laszlo, ed. "The Irrepressible Authority of the Tripartitum." In The Customary Law of The Renowned Kingdom of Hungary in Three Parts. Xiii-xxvi, Translated by Janos M. Bak, Peter Banyo, and Martyn Rady. Budapest: Central European University, 2005.

Pitt, Ingrid. The Ingrid Pitt Book of Murder, Torture and Depravity. London: B.J. Batsford, 2000.

Pollock, Linda A. "Parent-Child Relations." In The History of the European Family Volume One: Family Life in Early Modern Times, 1500-1789, edited by David I. Kertzer and Marzia Barbogli, 191-200, New Haven: Yale University Press, 2001.

Pointer, Sally. The Artifice of Beauty: A History and Practical Guide to Perfume and Cosmetics. Phoenix Mill: Sulton Publishing Limited, 2005.

Prescott, William. History of the Reign of Ferdinand and Isabella, The Catholic. New York: J.B. Lippincott \& Co., 1860.

Rady, Martyn. Nobility, Land and Service in Medieval Hungary. New York: Palgrave Publishers, 2000.

Riches, Samantha J. E. “'Hyr Wombe Insociale': The iconography of the Feminised Monster." In Pawns or Players: Studies on Medieval and Early Modern Women, edited by Christine Meeks and Catherine Lawless, 177-196, Dublin: Four Courts Press, 2003.

Rocck, Bernal. "The Atrocities of War in Early Modern Art." Translated by Olga Pollock. In Power Violence and Mass Death in Pre-Modern and Modern Times, edited by Joseph Canning, Hartmut Lehmann and Jay Winter, 129-140, Hampshire: Ashgate Publishing Limited, 2004.

Romay, Gabriel. The Dracula Myth. New York: Macmillan Publishers, 1975.

Romsland, Katherine. The Human Predator: A Historical Chronicle of Serial Murder and Forensic Investigation. New York: Berkley Books, 2005. 
Ronald M. Holmes and Stephan T. Holmes, eds. Contemporary Perspectives on Serial Murder. Thousand Oaks: Sage Publications, 1998.

Rublock, Ulinka. The Crimes of Women in Early Modern Germany. Oxford: Clarendon Press, 1999.

Ruff, Julius R. "Popular Violence and its Prosecution in Seventeenth and Eighteenth Century France." In Crimes, Law, and Popular Culture in Europe 1500-1900, edited by Richard McMahon, 32-51, Portland: William Publishing, 2008.

Ruff, Julius R. Violence in Early Modern Europe, 1500-1800. Cambridge: Cambridge University Press, 2001.

Scott, Donald F. The History of Epileptic Therapy: An Account of How Medication was Developed. Pearl River: The Parthenon Publishing Group, 1993.

SeGrove, Kerry. Women Serial and Mass Murderers: A Worldwide Reference 1580 through 1990. Jefferson: McFarland and Company, Inc. 1992.

Silverman, Lisa. Tortured Subjects: Pain, Truth, and the Body in Early Modern France. Chicago: University of Chicago Press, 2001.

Sorti, Raffaella. "The Material Conditions of Family Life." Translated by Caroline Beamish. In The History of the European Family Volume One: Family Life in Early Modern Times, 1500-1789, edited by David I. Kertzer and Marzia Barbogli, 3-23, New Haven: Yale University Press, 2001.

Stalberg, Michael. Experiencing Illness and the Sick Body in Early Modern Europe. New York: Palgrave Macmillan, 2011.

Stone, Michael H. Healing the mind: A History of Psychiatry from Antiquity to the Present. New York: Norton Press, 1997.

Stokes, Laura. Demons of Urban Reform: Early European Witch Trials and Criminal Justice, 1430-1530. New York : Palgrave MacMillan, 2011.

Sugar, Peter F., Peter Hanak and Tibor Frank, ed. A History of Hungary. Bloomington: Indiana University Press, 1990.

Szakaly, Ferenc. "The Early Ottomen Period, Including Royal Hungary, 1526-1606." In A History of Hungary, edited by Peter F. Sugar, Peter Hanak, and Tibor Franks, 83-99, Bloomington: Indiana University Press, 1990.

Szabo, Eva. Hungarian Practical Dictionary. New York: Hippocrene Books, 2005. 
Tedeschi, John. "Inquisitional Law and the Witch." In Early Modern European Witchcraft: Centers and Peripheries, edited by Bengt Ankarloo and Gustav Henningsen, 83-118, Oxford: Clarendon Press, 1990.

Temkin, Owsei. The Falling Sickness: A History of Epilepsy from the Greeks to the Beginnings of Modern Neurology, $2^{\text {nd }}$ ed. Baltimore: John Hopkins Press, 1971.

Thorne, Tony. Countess Dracula: The Life and Times of Elisabeth Bathory. London: Bloomberg Press, 1997.

Toth, Istvan Gyorgy. Literacy and Written Culture in Early Modern Central Europe. Budapest: Central European University Press, 2000.

de Trafford, Claire. "Share and Share Alike? The Marriage Portion, Inheritance and Family Politics." In Pawns or Players: Studies on Medieval and Early Modern Women, edited by Christine Meeks and Catherine Lawless, 36-48, Dublin: Four Courts Press, 2003.

Vallerani, Mossimo. Medieval Public Justice. Translated by Sarah Rubin Blonshei. Washington D.C.: The Catholic University of American Press, 2012.

Virágos, Gábor. The Social Archaeology of Residential Sites: Hungarian Noble Residences and their Social Context from the Thirteenth Through to the Sixteenth Century: An Outline for Methodology. Oxford: Archaeopress, 2006.

Vronsky, Peter. Female Serial Killers: How and Why Women Become Monsters. New York: Berkley Books, 2007.

Watt, Jeffery R. "The Impact of the Reformation and Counter-Reformation." In The History of the European Family Volume One: Family Life in Early Modern Times, 1500-1789, edited by David I. Kertzer and Marzia Barbogli, 125-154, New Haven: Yale University Press, 2001.

Weisser, Michael R. Crime and Punishment in Early Modern Europe. Atlantic Highlands: Humanities Press, 1979.

Whaley, Leigh Ann. Women and the Practice of Medical Care in Early Modern Europe 1400-1800. New York: Palgrave Macmillan, 2011.

Whitehead, Barbara J. “Introduction.” In Women's Education in Early Modern Europe: A History 1500-1800, edited by Barbara J. Whitehead, ix-Xvi, New York: Garland Publishing Inc., 1999.

Wiazzo, Pier Poola. "Mortality, Fertility, and Family." Translated by Caroline Beamish. In The History of the European Family Volume One: Family Life in Early Modern 
Times, 1500-1789, edited by David I. Kertzer and Marzia Barbogli, 157-187, New Haven: Yale University Press, 2001.

Wiesner, Merry E. Women and Gender in Early Modern Europe, $2^{\text {nd }}$ edition. Cambridge: Cambridge University Press, 2000.

William, Ian. "Early Modern Judges and the Practice of Precedent." In Judges and Judging in the History of the Common Law and Civil Law: From Antiquity to Modern Times, edited by Paul Brand and Joshua Getzler, 51-66, Cambridge: Cambridge University Press, 2012.

Williams, Neville. Powder and Paint: A History of the Englishwoman's Toilet, Elizabeth I - Elizabeth II. London: Longmans, Green and Co. 1957.

Wilson, Colin and Donald Seaman, The Serial Killers: A Study in the Psychology of Violence. New York: Carol Publishing Group Book, 1990.

Yalem, Marilyn. A History of the Wife. New York: Harper Collins Publishers, 2001.

Zimanyi, Vera. Economy and Society in $16^{\text {th }}$ and $17^{\text {th }}$ Century Hungary $(1526-1650)$. Budapest: Ahademiai Kiado, 1987. 